\title{
SssI DNS metiltranszferáz által katalizált citozin dezamináció
}

\author{
Ph. D. értekezés
}

Stier Ildikó

Témavezető: Dr. Kiss Antal

SzTE-TTIK, Biológiai Doktori Iskola

MTA Szegedi Biológiai Kutatóközpont, Biokémiai Intézet

Szeged, 2013 


\section{Tartalomjegyzék}

Rövidítések jegyzéke .

Az F17S és G19D mutáns M.Sssl enzimek létrehozása helyspecifikus mutagenezissel .................... 23

M.SssI fehérjevariánsok kifejeződésének ellenőrzése immunoblottal ........................................... 24

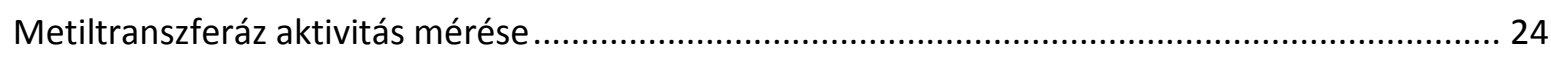

Trícium beépülésén alapuló metiltranszferáz aktivitás mérés.................................................. 24

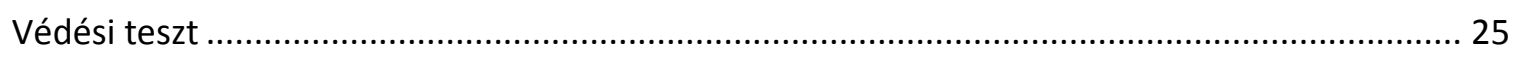

Metiltranszferáz aktivitás in vivo vizsgálata McrBC restrikciós emésztéssel szembeni

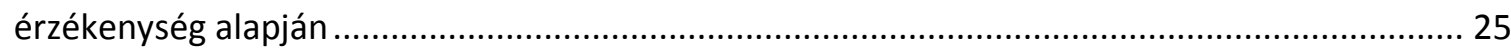

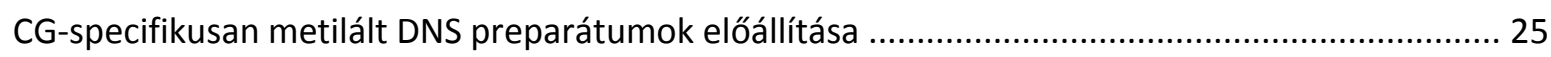

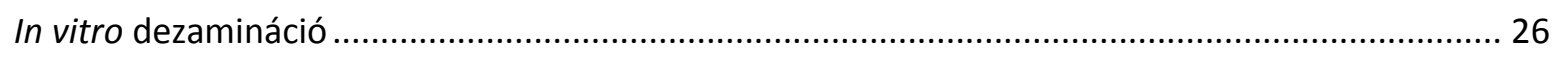

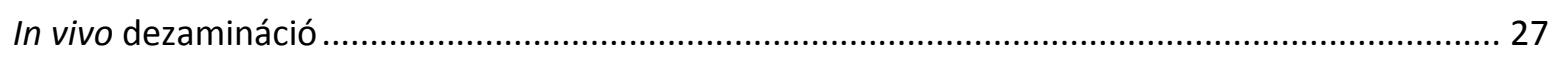

A reverzió gyakoriságának mérése (egyszerű in vivo dezaminációs teszt) …............................. 27

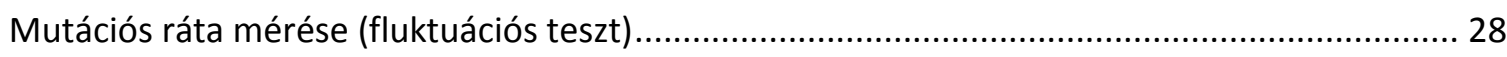

Oligonukleotidok és DNS fragmentumok radioaktív jelölése ...................................................... 28 
Jelölt DNS minták Mval emésztésének vizsgálata.

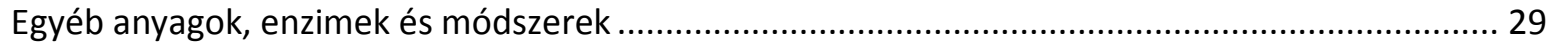

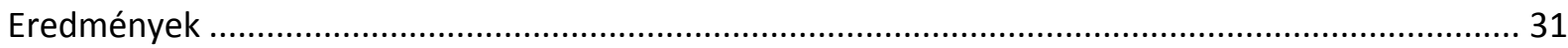

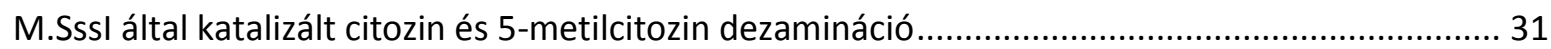

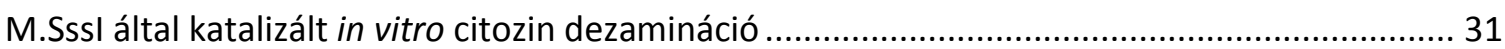

M.SssI variánsok in vivo metiltranszferáz aktivitásának jellemzése ...................................... 33

M.Sssl variánsok in vivo dezaminációs aktivitásának jellemzése .......................................... 35

Az M.Sssl variánsok in vitro metiltranszferáz aktivitásának jellemzése............................... 37

Az M.Sssl variánsok in vitro dezaminációs aktivitásának jellemzése .................................... 38

M.SssI által katalizált citozin és 5-metilcitozin dezamináció összehasonlítása......................... 39

M.Sssl-specifikus metiláció következtében megjelenő új Mval hasítási helyek .......................... 40

A metiláció-függő kettősszálú felismerési hely jellemzése .............................................. 41

A metiláció-függő kettősszálú hasítás jellemzése ......................................................... 43

M.Sssl által metilált $\mathrm{C}^{\mathrm{m5}} \mathrm{CSGG}(\mathrm{Bcnl})$ helyek egyszálú hasítása ................................................45

Az eredmények megvitatása ....................................................................................... 50

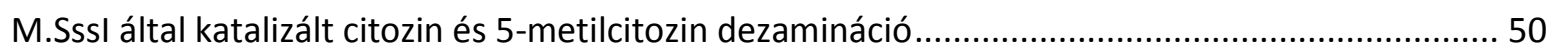

M.Sssl által katalizált in vitro dezamináció.................................................................... 50

M.Sssl enzimvariánsok által katalizált in vivo citozin dezamináció ...................................... 53

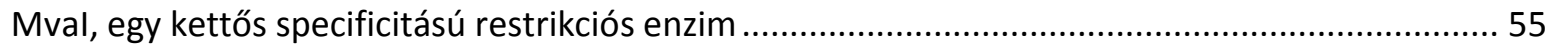

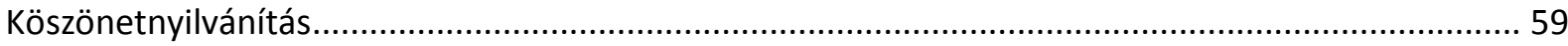

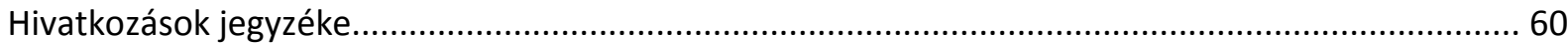

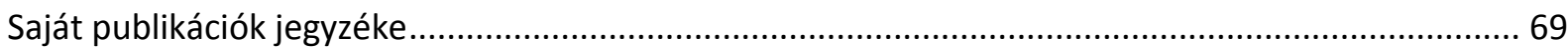

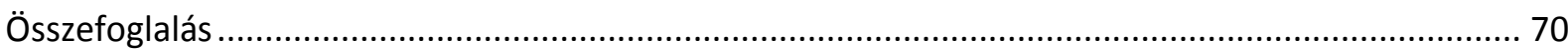

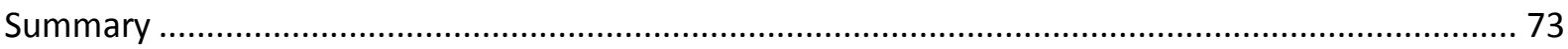




\section{Rövidítések jegyzéke}

\begin{tabular}{|c|c|}
\hline AA & 5'-amino-5'-dezoxiadenozin \\
\hline Ap & ampicillin \\
\hline C5-MTáz & DNS C5-citozin metiltranszferáz \\
\hline $\mathrm{Cm}$ & kloramfenikol \\
\hline CTP & citidin-trifoszfát \\
\hline DTT & ditiotreitol \\
\hline EDTA & etiléndiamin-tetraecetsav \\
\hline IPTG & izopropil- $\beta$-D-tiogalaktozid \\
\hline $\mathrm{Kn}$ & kanamicin \\
\hline LB & Luria-Bertani táptoldat \\
\hline MTáz & metiltranszferáz \\
\hline NTP & nukleozid-trifoszfát \\
\hline OD & optikai denzitás \\
\hline PCR & polimeráz láncreakció (polimerase chain reaction) \\
\hline PEG & polietilén-glikol \\
\hline PVDF & polivinilidin-fluorid \\
\hline $\mathrm{rpm}$ & percenkénti fordulatszám (rotation per minute) \\
\hline SAH & S-adenozil-L-homocisztein \\
\hline SAM & S-adenozil-L-metionin \\
\hline SDS & nátrium-dodecil-szulfát (sodium-dodecyl-sulphate) \\
\hline $\mathrm{SF}$ & szinefungin \\
\hline SOB & gazdag tápoldat (super optimal broth) \\
\hline $\mathrm{SOC}$ & glukózzal kiegészített gazdag tápoldat (super optimal broth with catabolite repression) \\
\hline TB & magas szénforrás tartalmú gazdag tápoldat (terrific broth) \\
\hline TBS & Tris-sel pufferelt sóoldat \\
\hline TBSTT & TBS+Tween-20 detergens oldat \\
\hline $\operatorname{Tdg}$ & timin-DNS glikoziláz \\
\hline $\mathrm{TE}$ & $10 \mathrm{mM}$ Tris- $\mathrm{HCl}(\mathrm{pH}=8)$ és $1 \mathrm{mM}$ EDTA oldata \\
\hline Tris & Tris-(hidroximetil)-metilamin \\
\hline Ung & uracil-DNS glikoziláz \\
\hline WT & vad típus \\
\hline
\end{tabular}




\section{Bevezető}

A Humán Genom Projekt egy évtizeddel ezelőtti befejezésével világossá vált, hogy a DNS nukleotidszekvenciája önmagában nem lehet felelős az élővilágban megfigyelt változatosságért. Mára köztudott, hogy a DNS adott bázisait és a kromatin szerkezetet érintő, jól meghatározott és dinamikusan változó epigenetikai módosítások elengedhetetlenek az élő szervezet normális fejlődéséhez és müködéséhez. A DNS metiláció az epigenetikai szabályozás egy kulcsfontosságú része, amely baktériumoktól emlősökig számos élőlényben megtalálható. A metilációt a DNS metiltranszferázok végzik, amelyek metildonorként S-adenozil-L-metionint (SAM) használva, szekvenciaspecifikus módon egy metilcsoportot juttatnak az adenin N6 illetve a citozin N4 vagy C5 atomjaira. A keletkező módosult bázisok a DNS természetes alkotóelemei, a nagy árokban elhelyezkedő metil csoport ugyanis nem változtat a bázisok Watson-Crick bázispárosodási képességein, de a DNS-t felismerő enzimek számára új információval bír (Jeltsch, 2002).

\section{A DNS metiláció szerepe prokariótákban}

Prokariótákban mindhárom típusú metiláció (C5-metilcitozin, N4-metilcitozin és N6-metiladenin) megtalálható, és leginkább a replikáció szabályozásban, a DNS hibajavításban és a saját, illetve idegen DNS megkülönböztetésében játszanak fontos szerepet.

Az előbbi két funkció főként adenin metiltranszferázokhoz kapcsolódik, mint pl. az Escherichia coli-ban is müködő Dam metiltranszferáz („DNA-A AdenineMethyltransferase"), amely a GATC szekvenciákon belül található adenint metilálja a DNS mindkét szálán. A teljesen metilált kromoszómális DNS replikációja során hemimetilált kettősszálú DNS keletkezik, amelyben az eredeti szülői szál igen, az újonnan szintetizálódott szál viszont nem metilált. Ez az állapot rövid ideig fennmarad, lehetőséget adva arra, hogy olyan enzimek kapcsolódjanak a DNS-hez, amelyek szerepet játszanak a hibajavításban, a kromoszóma replikációban és szegregációban, plazmid replikációban, illetve a transzpozíció és génkifejeződés szabályozásában. Annak ellenére, hogy a Dam metiltranszferáz nem esszenciális minden $\gamma$-proteobaktérium esetén, pl. az E. coli mutánsok életképesek, hiánya a legtöbb esetben rendellenes fenotípus, illetve 
megnövekedett mutációs ráta megjelenéséhez vezet (Marinus és Casadesus, 2009). Hasonlóan müködik az elsőként Caulobacter crescentus-ban kimutatott, $\alpha$ proteobaktériumokra jellemző, Ccr metiltranszferáz („Cell Cycle Regulated Methyltransferase") amely a GANTC szekvenciákon belül található adenint metilálja és a sejtciklus szabályozásában vesz részt. Hiánya a legtöbb esetben a sejt halálához vezet (Collier, 2009).

A saját és idegen DNS megkülönböztetésében ritkábban magányosan, gyakrabban restrikciós endonukleázhoz kötötten, a restrikciós-modifikációs (RM) rendszerek részeként müködő metiltranszferázok vesznek részt. Ezen rendszerek fő feladata a gazda genom integritásának megőrzése transzpozon illetve fág fertőzés esetén. Egyazon RM rendszer részét képező két enzim ugyanazt a DNS szekvenciát ismeri fel, amelynek metilációja meghatározott citozin illetve adenin nukleotidoknál védelmet biztosít az endonukleáz általi hasítással szemben. A sejtbe jutó idegen DNS általában nem rendelkezik az adott gazdára specifikus metilációval, így a DNS mindkét szálának hasítása révén az endonukleáz feldarabolja azt (Wilson és Murray, 1991). Több mint 40 évvel ezelőtti felfedezésük óta (Smith és Welcox, 1970) a biokémiailag vagy genetikailag jellemzett RM rendszerek száma mára közel 4000-re nőtt és a több mint 2400 ismert bakteriális és archea genom mintegy 90\%-a tartalmaz legalább egy lehetséges RM rendszert (Roberts és mtsai., 2010; Vasu és Nagaraja, 2013).

Sokféleségüket és széleskörü elterjedésüket több dolog is magyarázhatja. Egyrészt amellett, hogy genetikai „immunrendszerként” müködnek, a homológ rekombináció elősegítésével hozzájárulhatnak a genetikai variabilitáshoz és a mikrobiális evolúcióhoz (Arber, 2000), másrészt a környezetből származó idegen DNS felvételének szabályozása, illetve a törzs-specifikus metiláció kialakítása révén szerepük lehet a faji identitás fenntartásában is (Jeltsch, 2003). Egy harmadik elmélet szerint, mivel a posztszegregációs megsemmisítő mechanizmus illetve horizontális géntranszfer révén elösegítik önmaguk fenntartását és elterjedését, tulajdonképpen önző genetikai elemként müködnek (Kobayashi, 2001).

A restrikciós-modifikációs rendszerek az enzimek szerkezete, müködése, kofaktor igénye, a felismerési hely és egyéb jellegzetességeik alapján négy nagy csoportba (I-IV) sorolhatóak (Roberts, 2003). Nagy többségük a II. típusba tartozik, melyekre jellemző, hogy az enzimek általában rövid, palindróm szekvenciákat ismertnek fel, az endonukleáz a 
hasításhoz legtöbbször csak $\mathrm{Mg}^{2+}$-ot igényel, és a DNS mindkét szálát a felismerési helyen belül, vagy ahhoz nagyon közel, egy meghatározott helyen vágja (Pingoud és Jeltsch, 2001). Noha a legtöbb restrikciós enzimet gátolja a kanonikus MTáz általi metiláció, a IIM (metiláció irányított endonukleázok) alcsoport egy érdekes kivételnek számit: a GATC szekvenciát felismerő DpnI enzim például csak a metilált adenint tartalmazó célhelyet hasítja (Lacks és Greenberg, 1975). Fontos azonban megjegyezni, hogy ez az enzim különbözik a IV. típusba sorolható McrBC endonukleáztól (Raleigh, 1992; Raleigh és Wilson, 1986), amely szintén metil(citozin)-specifikus enzim, de nem rendelkezik egy jól meghatározott hasítási hellyel. Számos restrikciós enzim esetén megfigyelték azt is, hogy a célhely nem kanonikus metilációja nem föltétlenül gátolja az endonukleáz működését, de legtöbbször a hasítás sebességének csökkenéséhez vagy csak az egyik szál hasításához (nickeléséhez) vezet (Nelson és mtsai., 1993). Szintén kivételt képeznek a szigorú értelemben vett II. típusú enzimek közt az ún. nickelő enzimek, amelyek a DNS csak egyik szálát hasítják. Ilyen enzimek előfordulhatnak természetesen, mint pl. a N.BstNBI (Morgan és mtsai., 2000), lehetnek egy heterodimerként müködő enzim izolált alegységei (Xu és mtsai., 2007), vagy létrehozhatóak mesterségesen is különböző mutációkkal, mint pl. az AlwI restrikciós endonukleázból származtatott nickelő enzim (Xu és mtsai., 2001).

A II. típusú RM rendszerekhez tartozó enzimek egyszerű szerkezetük és a nagyszámú ismert, általában jól meghatározott specificitásuk következtében a modern molekuláris biológiai módszerek elengedhetetlen kellékeivé váltak, és a DNS-fehérje kölcsönhatások vizsgálatának rendkívül jó modellrendszerét képezik (Buryanov és Shevchuk, 2005; Roberts, 2005).

\section{A DNS metiláció szerepe eukariótákban}

Eukariótákban csak C5-citozin metiláció található, amely a DNS mindkét szálát érinti, és míg emlősökben főként CG dinukleotidokban fordul elő, addig gombákban (pl. Neurospora crassa) és növényekben (pl. Arabidopsis thaliana) más szimmetrikus és nem szimmetrikus szekvenciákon belül is megtalálható. A DNS metiláció előfordulása és mértéke nem tekinthető általánosnak az eukariótáknál: a Saccharomices cerevisie és számos gerinctelen törzs esetében például teljesen hiányzik, a Drosophila melanogasterben pedig nagyon kismértékü (Suzuki és Bird, 2008). Ezzel szemben emlősökben a CG szekvenciák mintegy 60-80\%-a metilált, amelyek térbeni és időbeni eloszlása nem véletlenszerü. A megfelelő metilációs mintázat kialakításáért és fenntartásáért főként 3 
metiltranszferáz felelős. A Dnmt1 „fenntartó” metiltranszferázként müködve a replikáció során keletkezett hemimetilált DNS-t ismeri fel, biztosítva a metilációs mintázat fenntartását sejtosztódás után. A Dnmt3a és b metilálatlan CG szekvenciák felismerésére is képesek, és valószínűleg a de novo metilációért felelősek pl. az embrionális fejlődés során. Egy negyedik, eukariótákban konzerváltnak tekinthető metiltranszferáz, a Dnmt2, még olyan fajoknál is megtalálható, ahol nincs kimutatható DNS metiláció. Ez az enzim feltételezhetően a tRNS metilációban játszik szerepet (Bestor, 2000; Hermann és mtsai., 2004).

Eukariótákban a DNS metiláció egyik legfontosabb funkciója a génkifejeződés szabályozása. A promoter régiók metilációja általában az adott gén kifejeződésének csökkenéséhez illetve kikapcsolásához vezet, egyrészt mivel a metil csoport fizikailag akadályozza számos transzkripciós faktor DNS-hez kötődését, másrészt a metiláció lehetővé teszi metil-CG-kötő fehérjék kapcsolódását amely hiszton deacetilázok megkötése és ezek müködése révén kromatinkondenzálódáshoz és ezáltal stabil génrepresszióhoz vezet (Fuks, 2005; Klose és Bird, 2006). A metiláció egyedfejlődés szabályozásában betöltött szerepére és esszenciális voltára utal, hogy mutáns DNS-metiltranszferázzal rendelkező egérembriók rendellenesen fejlődnek és homozigóta formában, a fejlődés adott szakaszában elpusztulnak (Li és mtsai., 1992). Ezen kívül a DNS metiláció részt vesz a genomikus bevésődésben (Li és mtsai., 1993), X kromoszóma inaktivációban (Mohandas és mtsai., 1981), illetve transzpozonok és repetitív szekvenciák metilációja révén a genomstabilitás fenntartásában is (Yoder és mtsai., 1997).

Figyelembe véve sokrétű szerepét, nem meglepő, hogy a megfelelően kialakított és fenntartott metilációs mintázat elengedhetetlen a magasabb rendű eukarióták fejlődéséhez és a szervezet normális müködéséhez. A rendellenes metiláció számos kórképpel, így neurodegeneratív betegségekkel, cukorbetegséggel, rákkal illetve az öregedéssel is összefüggésbe hozható (Jones, 2001). A DNS metilációt is felderítő epigenetikai kutatásoknak nagy jelentősége van nemcsak adott betegségek diagnosztizálásában, de az esetleges gyógymódok kidolgozásában is, így napjainkban nagy hangsúlyt kaptak azok a fejlesztések, amelyek lehetővé teszik bizonyos gének metilációs profiljának vizsgálatát és megkísérlik ennek összekapcsolását az adott gén szövet-specifikus kifejeződésével. Mára már számos módszer létezik a globális illetve a génspecifikus metilációs mintázat megállapítására is (Ammerpohl és mtsai., 2009). Ezek közül érdemes kiemelni az ún. biszulfitos DNS szekvenciameghatározást (Frommer és mtsai., 1992), amely azon a 
megfigyelésen alapszik, hogy egyszálú DNS-ben a nátrium-hidrogénszulfit, vagy biszulfit, sokkal gyorsabban képes specifikusan dezaminálni a citozint uracillá egy dihidrocitozinszulfonát intermedier kialakulásán keresztül (2. ábra/C), mint ahogy azt az 5metilcitozinnal teszi. A két bázis eltérő reakcióképessége feltehetően annak köszönhető, hogy 5-metilcitozin esetén a szulfonát-addukt sokkal lassabban jön létre (Hayatsu és mtsai., 1970; Wang és mtsai., 1980). A biszulfittal kezelt DNS felhasználható templátként egy PCR reakcióhoz, amelyben a keletkezett uracil (eredetileg metilálatlan citozin) timinként, az eredetileg C5-metilált citozin, pedig citozinként fog felsokszorozódni. A DNS szekvenciában létrejött változások kimutatására ezután számos módszer alkalmazható. A preferenciális citozin konverzió egymás utáni szulfonálás, hidrolitikus dezamináció, és deszulfonálás révén valósul meg, és bázispárosodásban részt nem vevő citozinok (tehát egyszálú DNS) esetén a leghatékonyabb. Noha a módszer több pontján is technikai nehézségeket rejteget, mint pl. DNS degradáció, nem teljes konverzió, PCR során keletkező hibák, ami téves értékeléshez vezethet (Laird, 2010; Warnecke és mtsai., 2002), mára már nagymértékben automatizálttá vált és egyike a legelterjedtebb metilációt vizsgáló alkalmazásoknak.

\section{C5-citozin metiltranszferázok}

A C5-citozin DNS metiltranszferázok evolúciós szempontból is érdekesnek tekinthetőek, hisz mind prokariótákban, mind eukariótákban megtalálhatóak. A prokarióta enzimek közül a legjobban jellemzett metiltranszferázok a II. típusba tartoznak. Ezek általában monomerként müködnek, így egyetlen kötődési esemény során a DNS csak egyik szálának metilációja valósul meg.

A különböző prokarióta citozin metiltranszferázok és az eukarióta CG metiltranszferázok 500 C-terminális aminosava jelentős mértékü szekvencia-homológiát mutat, ami alapján szerkezetükben 10 konzervált szekvenciamotívumot különböztethetünk meg. Ezek közül hat (I, IV, VI, VIII, IX és X) erősen, négy pedig gyengébben konzervált, és ugyanabban a sorrendben követik egymást az enzimcsalád minden tagjánál (Kumar és mtsai., 1994; Pósfai és mtsai., 1989). A VIII. és IX. motívumok közt egy méretében és aminosavszekvenciájában is nagy változatosságot mutató szakasz található, az ún. „variábilis" régió, amely a célszekvencia, és ezen belül a metilálandó citozin felismeréséért felelős (Klimasuaskas és mtsai., 1991; Mi és Roberts, 1992) (1. ábra). A variábilis régión belül ún. célhely felismerő domén (TRD, „Target Recognition Domain”) különíthető el, 
amely hasonló specificitású enzimeknél azonos mérettel és nagyon hasonló aminosavszekvenciával rendelkezik (Lauster és mtsai., 1989; Trautner és mtsai., 1996).

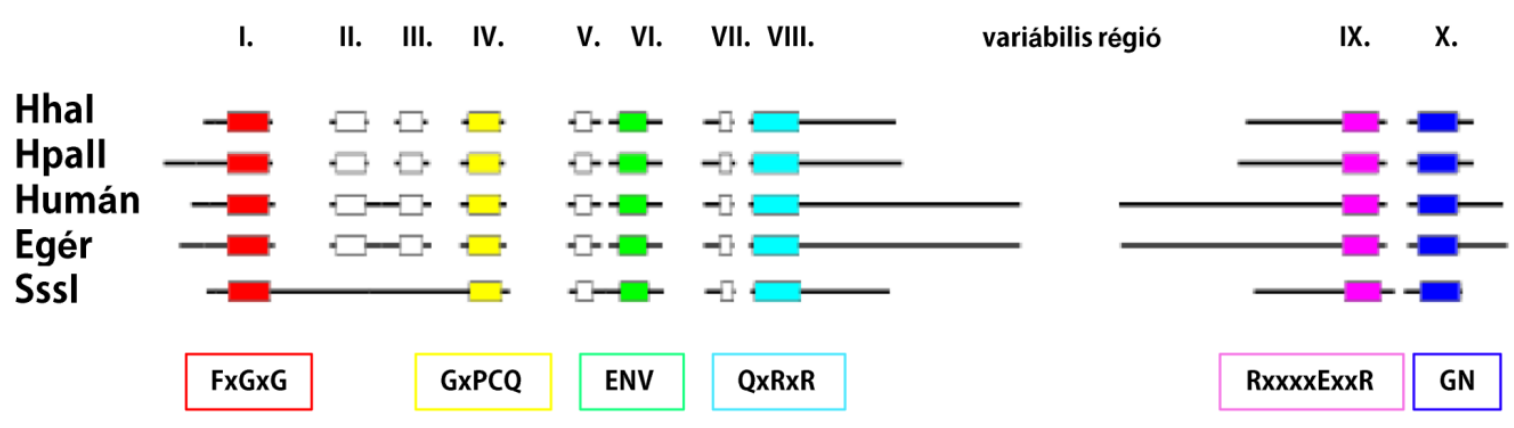

1. Különböző C5-citozin metiltranszferázok vázlatos szerkezete. A fehér téglalapok a gyengébben, a színesek pedig az erősen konzervált motívumokat jelölik. Az utóbbiakra jellemző konszenzus aminosavszekvencia az adott motívum alatt található (x, bármely aminosav lehet) (Kumar és mtsai., 1994 alapján).

Az enzimek háromdimenziós szerkezeti modelljét a különböző metiltranszferázok SAM-al illetve DNS-el alkotott kokristályainak röntgendiffrakciós elemzése révén állították fel. Az elsőként kristályosított és legjobban jellemzett enzimek a GCGC szekvenciát felismerő, Haemophilus haemolyticus-ból izolált M.HhaI és a GGCCspecifikus, Haemophilus aegypticus-ban található M.HaeIII voltak. Ahogy várható volt, a két enzim szerkezetében és müködésében sok a hasonlóság, amiből levonható néhány, a metiltranszferázokra általánosan jellemző következtetés is (Cheng és mtsai., 1993; Reinisch és mtsai., 1995; Youngblood és mtsai., 2007). Ezek alapján elmondható, hogy a metiltranszferázok általában két doménbe szerveződő fehérjék, amelyeket egy, a DNS kötésre alkalmas árok választ el egymástól. A konzervált motívumok eloszlása a két domén közt nagymértékủ aszimmetriát mutat: kilenc közülük (I-VIII és a X. motívum nagy része) a nagy doménben található, amely a SAM kötésért és a katalitikus mechanizmusért felelős.

A nagy domén (katalitikus domén) konzervált motívumai közül talán legfontosabb kiemelni az I. és IV. motívumot. A C5-MTázok I. motívuma (FxGxG, ahol x bármilyen aminosav lehet) az adenin, illetve N4-citozin metiltranszferázoknál is megtalálható, mi több, nagy hasonlóságot mutat egyéb S-adenozil-L-metionint (SAM), vagy S-adenozil-L- 
homociszteint (SAH) kötő, nem metiltranszferáz jellegü enzimekben is fellelhető motívummal, utalva szerepére (Kagan és Clarke, 1994; Klimasauskas és mtsai., 1989). Az I. motívum a M.HhaI illetve M.HaeIII enzimeken kívül, a citozin N4 nitrogénjét metiláló PvuII, illetve az N6-adenin specifikus TaqI MTázoknál is a metildonor kötő zseb részét képezi. Az itt található glicinben $(\mathrm{Gly}, \mathrm{G})$ gazdag régió lehetővé teszi, hogy a SAM kötésre alkalmas, zsebszerü üreg létrejöjjön, és ez által a metildonor adenin gyürüje megfelelően közel kerüljön a fehérje alapvázához. A fenilalanin (Phe, F) a zseb hidrofobitásának kialakításában vesz részt, elősegítve a metildonor kötését. SAM hiányában a kötő zsebet valószínüleg a Phe oldallánca zárja le (Cheng és mtsai., 1993; Gong és mtsai., 1997; Labahn és mtsai., 1994). A IV. motívum tartalmazza a katalitikus helyként számon tartott, konzervált prolin-cisztein dipeptidet, amely a nukleofil tiolt biztosítja. Az itt található cisztein (Cys, C) mutációja számos enzimnél csökkent aktivitáshoz vagy funkcióvesztéshez vezet (Cheng és mtsai., 1993; Mi és Roberts, 1993; Rathert és mtsai., 2007; Wilke és mtsai., 1988; Wyszynski és mtsai., 1993).

A kis domén (DNS felismerő domén) nagy részét a specificitást adó variábilis régió teszi ki, amely így mind térbeli szerkezetében, mind méretében nagymértékü heterogenitást mutat. A M.HhaI esetén a IX. motívum erős kapcsolatban áll a variábilis régióval is, biztosítva a kis domén strukturális vázát (Cheng és mtsai., 1993).

Az enzim által megkötött DNS a nagy árokkal a felismerő, a kis árokkal pedig a katalitikus domén felé néz. A célszekvencia megtalálása egy többlépéses reakció eredménye, amely egy nem-specifikus DNS kötődés után lineáris diffúzióval valósul meg, és a specifikus kötődést követően mind a DNS mind az enzim esetén nagyméretü konformációváltozást idéz elö.

\section{A C5-citozin metiltranszferázok működése}

A C5-citozin metiláció jól ismert reakció, melynek lépései általános érvényűnek tekinthetők az enzimcsaládon belül. A folyamat alapvetően a következő lépésekre bontható: egy specifikus enzim-DNS-SAM komplexum kialakulása, a metilálandó citozin kibillentése a DNS-kettős hélixből, kovalens fehérje-DNS intermedier kialakulása és metiltranszfer, végül a kovalens intermedier felbomlása és a termékek felszabadulása (2. ábra). A reakció során az enzim aktív helyén található cisztein-tiol nukleofil támadást intéz a citozin C6 atomja ellen, ami egy kovalens fehérje-DNS intermedier kialakulásához vezet. Ezt a citozin N3 atomjának átmeneti protonálása segíti az enzim egy szintén konzervált 
aminosava, az ENV tripeptid (VI. motívum) glutaminsavja (Glu, E) révén. Ennek hatására aktiválódik a citozin $\mathrm{C} 5$ atomja, lehetővé téve a metil-kation átadását a SAM-ról. A metiltranszfert követően, a keletkezett dihidro-citozin $\beta$-eliminációval bomlik fel. A reakció végtermékei a C5-metilcitozin és az S-adenozin-L homocisztein (SAH) (Chen és mtsai., 1991; Vilkaitis, 2001; Wu és Santi, 1987).

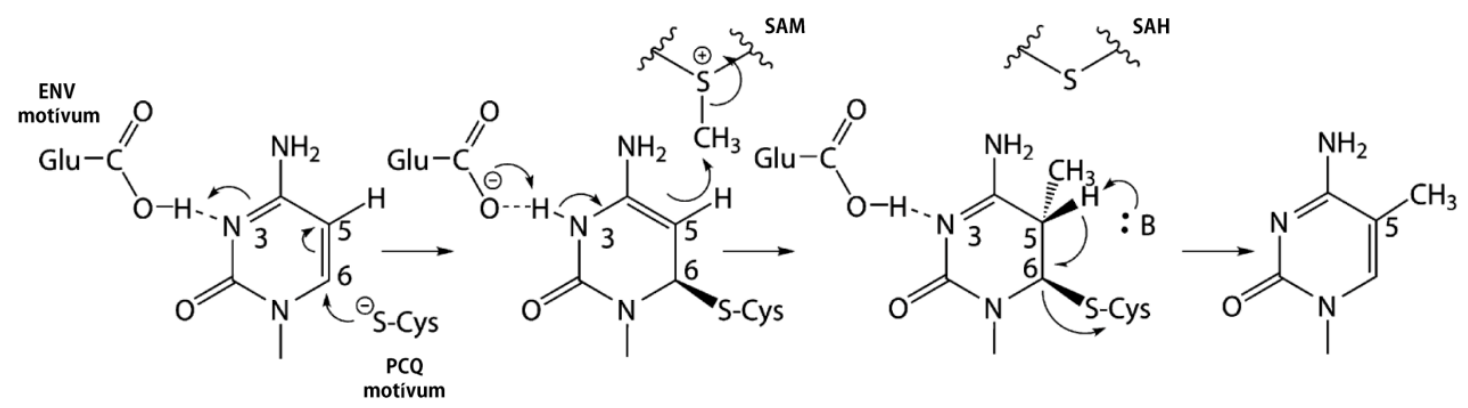

2. ábra. A C5-citozin metiltranszferázok által katalizált reakció (Darii és mtsai., 2007 alapján).

A B-DNS kettős hélixébe ágyazott, bázispárosodásban résztvevő citozin az ún. báziskifordulás („,base-flipping”) mechanizmus révén válik elérhetővé az enzimatikus reakció számára. Ennek során a metilálandó citozint az enzim mintegy $180^{\circ}$-al kifordítja a kettős spirálból, miközben a katalitikus hurok a DNS felé tolódik. A folyamat eredményeként a kilendült bázis és a SAM aktív metil csoportja kellően közel kerülnek egymáshoz egy, az enzim által formált, zárt katalitikus zsebben (Estabrook, 2004; Horton, 2004; Huang és mtsai., 2003; Klimasauskas és mtsai., 1994; Reinisch és mtsai., 1995). A kilendült bázissal szemben maradt magányos guaninnal az enzim hidrogénhídkötéseket alakít ki, ezáltal stabilizálva az energetikailag kedvezőtlen DNS konformációt. A rendelkezésre álló kristályszerkezetek, illetve különböző metiltranszferázok mutációs vizsgálatával sikerült kimutatni, hogy a báziskilendülésben szerepet játszó aminosavak a IV., VI. és VIII. konzervált motívumokban illetve a variábilis régión belül találhatóak (Cheng és Roberts, 2001; Mi és mtsai., 1995).

\section{Az M.SssI metiltranszferáz}

A Spiroplasma sp.-ből izolált ,árva” (nem RM rendszer részeként müködő) SssI metiltranszferáz, az egyetlen olyan prokarióta enzim, amely az emlősökben található C5- 
MTázokhoz hasonlóan, a CG szekvenciákon belüli citozint módosítja (Renbaum és mtsai., 1990). Az enzim processziven metilálja a DNS mindkét szálát (Renbaum és Razin, 1992), de érdekes módon, $\mathrm{Mg}^{2+}$ ionok jelenlétében a metiláció inkább disztributívvá válik (valószínüleg a csökkent DNS-hez való affinitás miatt) és az enzim gyenge topoizomeráz aktivitást mutat (Matsuo és mtsai., 1994). A 386 aminosavból álló enzim szekvenciájában kimutatható mind a 10 konzervált motívum, és számítógépes modellezés illetve mutációs vizsgálatok alapján elmondható, hogy valószínüleg a többi prokarióta metiltranszferázhoz hasonló szerkezettel és müködéssel rendelkezik (Darii és mtsai., 2007; Koudan és mtsai., 2004). Mivel röntgendiffrakciós szerkezet nem áll rendelkezésre, keveset lehet tudni a pontos DNS felismerési mechanizmusról, footprint analízissel kimutatták azonban, hogy az enzim a nagy árok felől létesít kapcsolatot a felismerési hely bázisaival kiterjedt kölcsönhatásba lépve a DNS cukor-foszfát gerincével is (Renbaum és Razin, 1995).

Specificitásának köszönhetően az M.SssI nagyon jól alkalmazható modellként a magasabb rendü eukariótákban előforduló citozin metiláció, illetve DNS-fehérje kölcsönhatások tanulmányozására, és rendkívül hasznos kísérleti eszköz az epigenetikai kutatások során (Galm, 2001; Jessen és mtsai., 2004; Xu és Bestor, 1997).

\section{Citozin és 5-metilcitozin dezamináció}

A citozin és különösképp az 5-metilcitozin $\left({ }^{\mathrm{m} 5} \mathrm{C}\right)$ kémiailag sokkal instabilabb, mint a többi nukleotid bázis. Mindkettő képes spontán, hidrolitikus reakció révén dezaminálódni aminek következtében uracil, illetve timin keletkezik. Normális fiziológiai körülmények közt a citozin dezamináció sebessége kettősszálú DNS-ben $2.6-7 \times 10^{-13} / \mathrm{s}$ körül van (Frederico és mtsai., 1990; Shen és mtsai., 1994; Zhang és Mathews, 1994), míg metilcitozin esetén ez valamivel nagyobb: $5.8 \times 10^{-13} / \mathrm{s}$ (Shen és mtsai., 1994) vagy $1.5 \mathrm{x}$ 10 $11 / \mathrm{s}$ (Zhang és Mathews, 1994). A keletkező T:G illetve U:G hibás bázispárok kijavítására baktériumokban legalább három rendszer képes: az uracil-DNS glikoziláz (Ung) általi, a nagyon rövid szakasz kijavítás (,very-short-patch”, VSP) illetve a metiláció által irányított hibás bázispárosodás kijavítás (,methyl-directed mismatch repair”, MMR). Ezek hatékonysága nagymértékben függ a hibás bázispár helyétől és a sejtek növekedési fázisától is. Ugyanakkor amellett, hogy az 5-metilcitozin spontán dezaminációja könnyebben végbemegy, mint a citoziné, a reakció következtében keletkezett timin a DNS saját bázisa, így felismerése és a hibás T:G bázispár kijavítása nehezebb, mint az U:G bázispároké. Ha a dezamináció során keletkezett hibás bázisok javítatlanul maradnak, ez, a 
$\mathrm{C} \rightarrow \mathrm{U} /{ }^{\mathrm{m} 5} \mathrm{C} \rightarrow \mathrm{T}$ útvonalon keresztül, $\mathrm{C}: \mathrm{G} \rightarrow \mathrm{T}: \mathrm{A}$ mutációk megjelenéséhez vezet. Mindezeket figyelembe véve elmondható, hogy az 5-metilcitozin mind prokariótákban mind eukariótákban fontos mutációforrás, és a metilált citozin „mutációs forró pontnak” tekinthető (Lutsenko és Bhagwat, 1999).

\section{C5-citozin metiltranszferázok által katalizált dezamináció}

A CㅡGG szekvenciát felismerő és az aláhúzással jelzett citozint módosító, prokarióta HpaII metiltranszferázról kimutatták, hogy a metildonor SAM hiányában fokozza a célzott citozin dezaminációját. Ugyan a reakció sokkal lassúbb, mint az enzim által katalizált metiláció, még mindig $10^{4}$-szer gyorsabb, mint a citozin spontán dezaminációja. Mind a SAM, mind a metiláció végterméke, a SAH, koncentráció-függő módon gátolják az enzim által katalizált dezaminációt (Shen és mtsai., 1992).

A jelenséget később több prokarióta metiltranszferáz, mint pl. M.EcoRII, Dcm, M.HhaI, M.SssI illetve az eukarióta Dnmt3a katalitikus alegysége esetén is kimutatták (Bandaru és mtsai., 1995; Métivier és mtsai., 2008; Wyszynski és mtsai., 1994; Yang és mtsai., 1995). Néhány enzim in vivo is képes mutagén hatást kifejteni, így pl. a HpaII, EcoRII vagy Dcm metiltranszferáz jelenléte $E$. coli-ban akár 50 -szeresére is növelheti a célszekvencián belüli $\mathrm{C} \rightarrow \mathrm{T}$ mutációk gyakoriságát. Ez azonban valószínüleg nem a metiltranszferázok által katalizált folyamat, hisz a sejtekben található SAM koncentráció elegendő a dezamináció gátlásához, másrészt M.EcoRII esetén a megnövekedett mutációs gyakoriság uracil javító rendszer mellett is kimutatható volt (Bandaru és mtsai., 1995, 1996; Wyszynski és mtsai., 1994). Ezzel szemben egy, a metildonor kötésére képtelen, M.HpaII mutáns enzim mind in vitro, mind in vivo, SAM jelenlétében is, hatékonyan képes a $\mathrm{C} \rightarrow \mathrm{U}$ konverzió katalizálására. Ez a mutáns enzim erősebben kötődik a létrehozott $\mathrm{U}: \mathrm{G}$ hibás bázispárhoz, mint a kanonikus $\mathrm{C}: \mathrm{G}$ felismerő helyhez, gátolja a megfelelő javítást, így in vivo mutátorként müködik (Shen és mtsai., 1995). Az MspI MTáz érdekes módon in vitro nem mutat fokozott citozin dezaminációt, E. coli-ban kifejezve viszont mutagén hatása összehasonlítható a többi vizsgált prokarióta enzimmel (Zingg és mtsai., 1998). A már metilált citozin enzim általi dezaminációja valószínütlenebb, mint a citoziné, M.EcoRII esetén azonban kimutatták, hogy ez mégis lehetséges. A reakció sokkal lassúbb, mint a $\mathrm{C} \rightarrow \mathrm{U}$ konverzió, de az 5-metilcitozin spontán, hidrolitikus dezaminációjához képest nagyságrendekkel gyorsabb (Yebra és Bhagwat, 1995). Az M.SssI esetén egy teljesen in vitro rendszert használva szintén kimutatták, hogy a citozin mellett az 5-metilcitozin 
dezaminációt is képes katalizálni, sőt ez utóbbit nagyobb hatékonysággal végzi (Métivier és mtsai., 2008).

A legtöbb prokarióta metiltranszferáz általi dezaminációt egy nagy érzékenységü genetikai teszttel bizonyították, amely valamilyen antibiotikum-rezisztencia reverzióján alapul. Egy plazmid DNS-en található rezisztencia gént egy vagy több, mesterségesen beiktatott pontmutáció létrehozásával inaktiváltak oly módon, hogy a metiltranszferáz által felismert citozin dezaminációja és az ezt követő replikáció során megjelenő timin vissza tudja majd állítani a funkciót. A C5-MTázzal inkubált plazmidot uracil hibajavító rendszerrel nem rendelkező gazdába transzformálva a rezisztens revertánsok számából megállapítható a dezamináció gyakorisága. Antibiotikum-rezisztencia helyett egyes kísérletekben egy inaktív lacZ gén reverzióját követték nyomon kék-fehér szelekció felhasználásával. A Dnmt3a katalitikus alegysége esetén ezzel szemben egy teljesen in vitro rendszert használtak, amely a metiláció célhelyét is tartalmazó oligonukleotidok uracil-DNS glikozilázzal (Ung) vagy timin-DNS glikozilázzal (Tdg) való emésztésén és az ezt követő kvantitatív PCR elemzésen alapszik. Az Ung illetve Tdg enzimek a dezamináció során keletkező U:G és T:G hibás bázispárokat ismerik fel és hasítják a szubsztrát oligonukleotidot, ezáltal csökkentve, vagy meggátolva annak PCR általi sokszorosítását. A metiltranszferázzal és utána glikozilázzal kezelt DNS valamint a kezeletlen minta PCR termékeinek kvantitatív összehasonlításából következtetni lehet a dezamináció mértékére. Úgy tünik az enzimatikus dezamináció vizsgálatában fontos lehet maga a felhasznált rendszer is, hisz az M.SssI esetén például a kanamicin-rezisztencia reverzióján alapuló és az elöbb említett in vitro vizsgálat is kimutatta a citozin dezaminációs képességet (Métivier és mtsai., 2008; Zingg és mtsai., 1996), míg a lacZ gén reverzióját vizsgálva ezt nem tudták igazolni (Zhang és Mathews, 1994).

Az enzimatikus citozin dezamináció feltehetően a metiláció során is létrejövő 5,6dihidro-citozin intermedier kialakulásán alapszik, akárcsak egyes kémiai anyagok, mint pl. a biszulfit általi konverzió (3. ábra/B és $\mathbf{C}$ ). Az enzim által, a citozin $\mathrm{C} 6$ nukleofil támadásával beindított reakció következtében a citozin C5 atomja helyi negatív töltést kap. SAM hiányában ennek a semlegesítése valószínüleg egy, a környezetből felvett proton révén valósul meg. A kialakult dihidro-citozin származék megegyezik a biszulfit konverzió során létrejövő intermedierrel, mely vizes közegben könnyen dezaminálódik. (Selker, 1990; Shen és mtsai., 1992; Zingg és mtsai., 1996). Az enzim szerepe a reakcióban tulajdonképpen az, hogy a citozin N3 protonálása és ez által a C5 aktiválása révén elősegíti 
az intermedier kialakulását, ezért az aktív tiolt nem tartalmazó mutáns enzimek képtelenek beindítani a fent említett reakciót. Ezt M.EcorII illetve M.HhaI esetén kísérletesen is bebizonyították: az aktív cisztein helyén alanint vagy szerint tartalmazó mutánsok nem mutatták a vad típusú enzimek esetén megfigyelt $\mathrm{C} \rightarrow \mathrm{U}$ konverziót (Wyszynski és mtsai., 1994; Yang és mtsai., 1995).

A<smiles>CN1C(=O)N=C(N)[CH][C@H]1F</smiles>

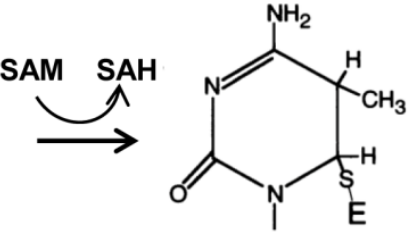<smiles>CC=CC</smiles><smiles>CC1=CN(C)N(C)C=C1F</smiles>

B

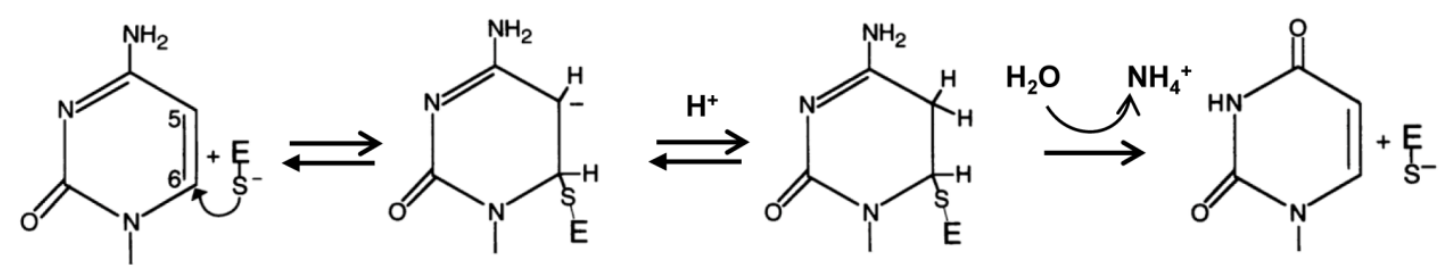

C<smiles>Cn1ccc(N)nc1=O</smiles>

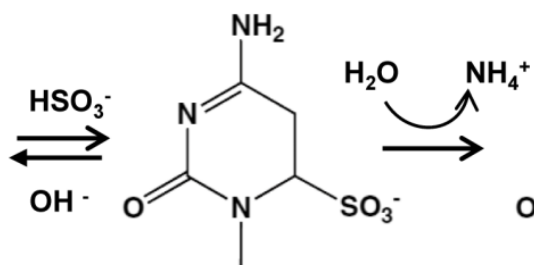<smiles>CN1C(=O)NC(=O)CC1[S+](=O)(=O)O</smiles><smiles>Cn1ccc(=O)[nH]c1=O</smiles>

3. ábra. Citozin C5-metiláció és dezamináció (Hayatsu, 2008; Wyszynski és mtsai., 1994 alapján). (A) C5citozin MTázok által katalizált metiláció SAM jelenlétében. (B) C5-citozin MTázok által katalizált citozin dezamináció SAM hiányában. (C) Biszulfit által katalizált citozin dezamináció.

\section{Metiltranszferáz inhibitorok hatása az enzimatikus citozin dezaminációra}

Kimutatták, hogy egyes SAM analógok, mint a szinefungin (SF), amely a metiláció egy ismert gátlószere, illetve egy adenozin származék, az 5'-amino-5'-dezoxiadenozin (AA), fokozzák az enzimatikus citozin dezaminációt: M.HpaII, M.SssI illetve M.EcoRII esetén például tízszer magasabb dezaminációt mértek AA jelenlétében, mint önmagában az enzimmel. Ezek az amino-analógok amellett, hogy fokozzák ezt a reakciót, képesek a 
SAM illetve SAH általi gátlás leküzdésére is és így a metildonor jelenlétében is elősegítik a $\mathrm{C} \rightarrow \mathrm{U}$ konverziót. Mi több, annak ellenére, hogy az M.MspI önmagában nem képes a citozin dezaminációra, AA illetve SF jelenlétében ez ennél az enzimnél is kimutatható. Eredetileg azt feltételezték, hogy az analógok a citozin C5 atomjának enzim általi protonálását segítik elő, ezáltal hozzájárulva a labilis intermedier kialakulásához, de a későbbiekben bebizonyították, hogy hatásukat valószínűleg más módon fejtik ki (Sharath és mtsai., 2000; Zingg és mtsai., 1996; Zingg és mtsai., 1998). Noha a folyamat még nem teljesen tisztázott, minden bizonnyal a citozin $\mathrm{C} 4$ atomjának hidroxilációja révén valósul meg, amelyet, a metiláció során az enzim által végzett, N3 protonálása tesz lehetővé. Az AA, és valószínűleg a többi vizsgált SAM analóg is, két úton fejtheti ki hatását: bázisként müködve vizes közegben reaktív hidroxidion keletkezéséhez vezetnek a C4 atom közelében, vagy savként az N4 protonálása révén elősegítik az aminocsoport eliminációját ammóniumion formájában. Mindkét mechanizmus a $\mathrm{C} 4$ atom víz általi direkt támadásán alapszik, így jelenlétükben nincs szükség a citozin C6 atomjának enzim általi nukleofil támadására. Ezt kísérletesen be is bizonyították: a katalitikus cisztein helyén alanint tartalmazó, inaktív M.EcoRII mutáns önmagában nem, AA jelenlétében viszont képes a $\mathrm{C} \rightarrow \mathrm{U}$ dezamináció katalizálására. Az enzim szerepe ebben a reakcióban nem teljesen világos, de feltételezhetően egyrészt szintén részt vesz az N3 protonálásában, másrészt maga a reakció csak akkor mehet végbe, ha a célzott citozin hozzáférhető, ami az enzim általi „,bázis kilendítés” nélkül nem valósulna meg. A jelenséget nem vizsgálták olyan mutáns enzimmel, amely képtelen a citozin kilendítésére, de az enzim elengedhetetlen szerepére utal, hogy C5-MTáz jelenléte nélkül, önmagában egyik SAM analóg sem vezet $\mathrm{C} \rightarrow \mathrm{U}$ konverzióhoz (Sharath és mtsai., 2000). 


\section{Célkitűzés}

A genom metilációs mintázata, az 5-metilcitozinok genomi és gén-specifikus eloszlása intenzív kutatások célpontja, melynek velejárója, hogy az ezt vizsgálni hivatott módszerek tárháza is rohamosan bővül. A citozin és 5-metilcitozin nátriumhidrogénszulfittal szemben mutatott eltérő reakcióképességén alapuló biszulfitos DNS szekvenciameghatározás egyike az epigenetikai kutatás legfontosabb módszereinek. A biszulfit által indukált reakció nagy hasonlóságot mutat az egyes citozin metiltranszferázok által meghatározott körülmények közt katalizált citozin dezaminációval.

Ezen a hasonlóságon elindulva doktori munkám során főként arra voltunk kíváncsiak, hogy az M.SssI felhasználható-e a biszulfitos reakció enzimatikus alternatívájaként az epigenetikailag fontos CG dinukleotidokban található metilált és metilálatlan citozin megkülönböztetésére kettősszálú DNS-ben. Munkánkat az motiválta, hogy a biszulfitos konverzió enzimatikus reakcióval való helyettesítése kiküszöbölhetné a reakció használatát gyakran nehezítő egyes technikai problémákat. Ezzel kapcsolatban a következő kérdésekre kerestük a választ:

- Képes-e az SssI MTáz katalizálni a citozin dezaminációját? Ez a kérdés azért volt indokolt, mert az irodalomban erre vonatkozóan ellentmondásos adatok voltak (1. fent).

- Képes-e az SssI MTáz katalizálni az 5-metilcitozin dezaminációját?

- Találunk-e olyan reakciókörülményeket, amelyek között az M.SssI által katalizált citozin és 5-metilcitozin dezamináció sebességeinek különbsége eléri a biszulfitos konverzióban mutatott különbséget?

- Tudunk-e olyan körülményeket teremteni, hogy az SssI MTáz in vivo, SAM jelenlétében is mutasson citozin dezaminációt?

Az M.SssI-el végzett munka során egy véletlen megfigyelés következtében észrevettük, hogy a CG-metiláció új szubsztráthelyeket teremt az MvaI restrikciós enzim számára. Ezek az új hasítóhelyek különböztek az MvaI ismert CCWGG (W lehet A vagy T) szubsztráthelyeitől, így célul tüztük ki ezen új, metiláció-függő szubsztráthelyek azonosítását illetve a hasítás mechanizmusának tisztázását. Az új felismerési helyek azonosítása fényt derített az MvaI endonukleáz egy eddig nem ismert aktivitására. 


\section{Anyagok és módszerek}

\section{Baktérium és bakteriofág törzsek, tenyésztési körülmények}

A munka során használt baktérium és fág törzsek jellemzői az 1. táblázatban találhatóak.

\begin{tabular}{|c|c|c|}
\hline Törzs & Genotípus & Hivatkozás \\
\hline $\begin{array}{l}\text { Escherichia coli } \\
\text { DH10B }\end{array}$ & $\begin{array}{l}\mathrm{F}^{-} \text {endA1 recA1 galU galK deoR nupG rpsL } \triangle \text { lacX74 } \varphi \\
80 \text { lacZ } \triangle M 15 \text { araD139 } \Delta \text { (ara leu) } 7697 \text { mcrA } \Delta(\text { mrr- } \\
h s d R M S-\text { mcrBC) } \lambda^{-}\end{array}$ & $\begin{array}{l}\text { (Durfee és } \\
\text { mtsai., 2008) }\end{array}$ \\
\hline $\begin{array}{l}\text { Escherichia coli } \\
\text { DH5 } \alpha\end{array}$ & $\begin{array}{l}\mathrm{F}-\Phi 80 \text { lacZ } \Delta \mathrm{M} 15 \Delta(\text { lacZYA-argF) } \mathrm{U} 169 \text { recA1 end } \mathrm{A} 1 \\
h s d \mathrm{R} 17(\mathrm{rK}-, \mathrm{mK}+) \text { phoA sup } \mathrm{E} 44 \lambda-\text { thi-1 gyrA96 relA1 }\end{array}$ & $\begin{array}{l}\text { (Woodcock és } \\
\text { mtsai., 1989) }\end{array}$ \\
\hline $\begin{array}{l}\text { Escherichia coli } \\
\text { ER1821 }\end{array}$ & $\begin{array}{l}\mathrm{F}^{-} \mathrm{glnV44} \text { e14 }\left(\mathrm{Mcr}^{-}\right) \text {rfbD1? relA1? endA1 spoT1? thi-1 } \\
\Delta(\mathrm{mcrC}-\mathrm{mrr}) 114: \because \mathrm{S} 10\end{array}$ & $\begin{array}{l}\text { (Waite-Rees és } \\
\text { mtsai., 1991) }\end{array}$ \\
\hline $\begin{array}{l}\text { Escherichia coli } \\
\text { ER2357 }\end{array}$ & $\begin{array}{l}\text { [endA1 thi-1 supE44 mcr-67 ung-1 dut } \Delta(\text { argF-lac }) \mathrm{U} 169 \\
\Delta(\text { mcrC-mrr }) 114:: \mathrm{IS} 10 \text { recA1 F4 proAB lacIq ZDM15 } \\
\left.z z f:: \operatorname{Tn} 10\left(\mathrm{Tet}^{\mathrm{R}}\right)\right]\end{array}$ & $\begin{array}{l}\text { E. A. Raleigh } \\
\text { ajándéka }\end{array}$ \\
\hline $\begin{array}{l}\text { Escherichia coli } \\
\text { XL1-Blue MRF }\end{array}$ & $\begin{array}{l}\Delta(m c r A) 183 \Delta(\text { mcrCB-hsdSMR-mrr) } 173 \text { endA1 supE44 thi-1 } \\
\text { recAl gyrA96 relA1 lac }\left[F^{\prime} \text { proAB lacl }{ }^{q} Z \Delta M 15 \text { Tn5 }\left(\mathrm{Kan}^{\mathrm{R}}\right)\right.\end{array}$ & Stratagene \\
\hline $\begin{array}{l}\text { Escherichia coli } \\
\mathrm{K} 1053(\mathrm{BW} 313 \mathrm{~F}+)\end{array}$ & dut, ung, thi-1, relA, spoT1/F'lys $A$ & (Kunkel, 1985) \\
\hline f1 R176 fág & & $\begin{array}{l}\text { (Russel és } \\
\text { mtsai., 1986) }\end{array}$ \\
\hline
\end{tabular}

\section{1. táblázat. Felhasznált baktériumtörzsek és genotípusuk}

Az E. coli ER2357-kanS ung és DH10B-kanS ung ${ }^{+}$sejtekben a kromoszómán található a pUP41-ből származó inaktív kanamicin-rezisztencia gén. Létrehozásukhoz a kanS-H94 allélt tartalmazó pUP41 (Beletskii és Bhagwat, 2001) BstBI-DraI (894bp) fragmentumát a pMS26 plazmid BstBI és PmeI helyei közé építettük majd, a Sibley és Raleigh által leírt, Tn7 transzpozíción alapuló módszerrel bejuttattuk mindkét gazda kromoszómájába. A Tn7 transzpozíció helyspecifikusságából adódóan a kanS gén a kromoszóma egy meghatározott helyére épül be mindkét gazda esetén. Ezt kolónia PCR-el ellenőriztük (Sibley és Raleigh, 2011).

A baktériumokat általában LB (Luria-Bertani) tápoldatban vagy táplemezen tenyésztettük $37^{\circ} \mathrm{C}$ - vagy $30^{\circ} \mathrm{C}$-on. A táplemezek elkészítéséhez $1,5 \%$ agart használtunk. Fehérjetisztításhoz TB, elektrokompetens sejtek készítéséhez pedig SOB tápoldatban 
növesztettük a baktériumokat. Elektroporálást követően a sejteket SOC tápfolyadékban regeneráltuk (Sambrook és Russell, 2006).

A felhasznált antibiotikumokat a következö végkoncentrációban alkalmaztuk: 100 $\mu \mathrm{g} / \mathrm{ml}$ ampicillin (Ap), $50 \mu \mathrm{g} / \mathrm{ml}$ kanamicin (Kn), $25 \mu \mathrm{g} / \mathrm{ml}$ kloramfenikol (Cm). Az M.SssI fehérje kifejeződésének gátlásához a tápoldatot $0,2 \%$ glukózzal, indukáláshoz pedig $0,1 \%$ L-arabinózzal egészítettük ki, és a sejteket $30^{\circ} \mathrm{C}$-on növesztettük. M.PspGI metiltranszferáz esetén a fehérje termelést $300 \mu \mathrm{M}$ IPTG hozzáadással indukáltuk és a sejteket szobahőmérsékleten növesztettük.

\section{Plazmidok}

A munka során felhasznált plazmidokat a 2. táblázat mutatja be.

\begin{tabular}{|c|c|c|c|}
\hline $\begin{array}{l}\text { Megnevezés } \\
\text { (rezisztencia) }\end{array}$ & Fontosabb jellemző & Felhasználás & Hivatkozás \\
\hline pUP41 $\left(\mathrm{Ap}^{\mathrm{R}}, \mathrm{Kn}^{\mathrm{S}}\right)$ & $\begin{array}{l}\text { Tartalmazza a Tn5 kanamicin- } \\
\text { rezisztencia gén egy mutáns } \\
\text { allélját (kanS-H94) }\end{array}$ & $\begin{array}{l}\text { Citozin dezamináció } \\
\text { szubsztrátja }\end{array}$ & $\begin{array}{l}\text { (Beletskii és } \\
\text { Bhagwat, 2001) }\end{array}$ \\
\hline pBHNS-MSssI $\left(\mathrm{Ap}^{\mathrm{R}}\right)$ & $\begin{array}{l}\text { C-terminálisan 6xHis-jelöléssel } \\
\text { ellátott M.SssI (C368A) fehérje } \\
\text { génjét tartalmazza }\end{array}$ & M.SssI túltermelés & $\begin{array}{l}\text { (Rathert és mtsai., } \\
\text { 2007) }\end{array}$ \\
\hline pBSss-16 $\left(\mathrm{Ap}^{\mathrm{R}}\right)$ & $\begin{array}{l}\text { Az sssIM gén 5' felét } \\
\text { tartalmazza BamHI-SacI } \\
\text { fragmentumon a pBluescript } \\
\text { SK+ vektorba klónozva }\end{array}$ & Irányított mutagenezis & $\begin{array}{l}\text { Kiss A., közletlen } \\
\text { eredmény }\end{array}$ \\
\hline pB-M.SssI $\left(\mathrm{Ap}^{\mathrm{R}}\right)$ & $\begin{array}{l}\text { Az sssIM gént tartalmazó } \\
\text { pBAD24 túltermelö vektor }\end{array}$ & $\begin{array}{l}\text { pSTC-M.SssI plazid } \\
\text { létrehozása }\end{array}$ & $\begin{array}{l}\text { Kiss A., közletlen } \\
\text { eredmény }\end{array}$ \\
\hline pST76-C $\left(\mathrm{Cm}^{\mathrm{R}}\right)$ & $\begin{array}{l}\text { Höérzékeny ColEI kompatibilis } \\
\text { replikonnal rendelkezik }\end{array}$ & $\begin{array}{l}\text { pSTC-M.SssI plazid } \\
\text { létrehozása }\end{array}$ & $\begin{array}{l}\text { (Pósfai és mtsai., } \\
\text { 1997) }\end{array}$ \\
\hline pMS26 $\left(\mathrm{Ap}^{\mathrm{R}}\right)$ & $\begin{array}{l}\text { Hőérzékeny replikonnal } \\
\text { rendelkezik, az MCS régió a } \\
\text { Tn7R és Tn7S transzpozíciós } \\
\text { hely közt található }\end{array}$ & $\begin{array}{l}\text { kanS-H94 allél } \\
\text { beültetése ER2357 és } \\
\text { DH10B sejtek } \\
\text { kromoszómájába }\end{array}$ & $\begin{array}{l}\text { (Sibley és Raleigh, } \\
\text { 2011) }\end{array}$ \\
\hline $\begin{array}{l}\text { pACYC184-M.PspGI } \\
\left(\mathrm{Cm}^{\mathrm{R}}\right)\end{array}$ & Tartalmazza a $p s p R I M$ gént & $\begin{array}{l}\text { pACYC184- } \\
\text { M.PspGI(S) } \\
\text { létrehozása }\end{array}$ & $\begin{array}{l}\text { Shuang-yong Xu } \\
\text { (New England } \\
\text { Biolabs) } \\
\text { bocsájtotta } \\
\text { rendelkezésünkre }\end{array}$ \\
\hline pTZ-Bsp5 $\left(\mathrm{Ap}^{\mathrm{R}}\right)$ & Tartalmazza a $b s p R I M$ gént & $\begin{array}{l}\text { pTZBspDX } \\
\text { létrehozása }\end{array}$ & $\begin{array}{l}\text { (Raskó és mtsai., } \\
\text { 2010) }\end{array}$ \\
\hline
\end{tabular}


A további plazmidkonstrukciókat a munka során hoztuk létre.

A pSTC-M.SssI $\left(\mathrm{Cm}^{\mathrm{R}}\right)$ plazmid az M.SssI metiltranszferáz génjét tartalmazza. Létrehozásához a pB-M.SssI plazmid NsiI-PstI fragmentumát átklónoztuk a pST76-C PstI helyére. Mivel a plazmid ColEI kompatibilis replikációs origóval rendelkezik, ezt használtuk fel a pUP41plazmid in vivo metilációjához.

A pSTdC-MSssI $\left(\mathrm{Cm}^{\mathrm{R}}\right)$ plazmidot pSTC-M.SssI-ből, a 98bp-os AseI-PstI fragmentum eltávolításával hoztuk létre. A deléció célja a BamHI és SacI helyek eltávolítása volt, amely a későbbi WT, F17S és G19D sssIM gének klónozását tette könnyebbé ebbe a vektorba. Ezt a plazmidot használtuk fel az in vivo dezaminációs kísérletekben a pUP41-el való kettős transzformáláshoz.

A pSTdC-MSssI(F17S), pSTdC-MSssI(G19D), pBHNS-MSssI(F17S) és pBHNSMSssI(G19D) plazmidok az M.SssI mutáns variánsait kódolják amelyeket helyspecifikus mutagenezissel (Kunkel, 1985) hoztunk létre (lásd később).

Az összes sssIM gént tartalmazó plazmidon az MTáz kifejeződés az L-arabinóz által indukálható $\mathrm{P}_{\mathrm{BAD}}$ promoter és az AraC fehérje szabályozása alatt áll (Guzman és mtsai., 1995).

A pACYC184-M.PspGI(S) $\left(\mathrm{Cm}^{\mathrm{R}}\right)$ plazmid tulajdonképpen egyetlen SmaI felismerési helyet tartalmazó pACYC184-M.PspGI. Létrehozására az eredeti plazmid egyedi XbaI helyére ligáltuk az önmagával részlegesen komplementer AK244 oligonukleotidot. A plazmidot az M.SssI-specifikusan metilált SmaI helyek MvaI általi hasításának kimutatására használtuk.

A pTZ-BspDX plazmid a pTZ-Bsp5 plazmidból származik. Ez utóbbiból kiejtve az XbaI fragmentumot inaktiváltuk a BspRI metiltranszferáz génjét. A plazmidot a BspRI metiltranszferáz felismerési helyével átfedő metiláció-függő MvaI hasítás vizsgálatánál használtuk.

A plazmid DNS-t általában 1,5 ml-s kultúrákból alkalikus feltárással tisztítottuk (Sambrook és Russell, 2006). Nagyobb tisztaságú DNS mintákhoz a GeneJet Plasmid Purification (Fermentas/Thermo Scientific), nagyobb mennyiségü tiszta plazmid előállításához pedig a GeneElute Hp Plasmid Midiprep (Sigma) kiteket használtuk a 
forgalmazó utasításait követve. Emésztett DNS fragmentumok gélből izolálása a GeneJet Gel Extraction (Fermentas/Thermo Scientific) kitel történt.

\section{Oligonukleotidok}

A felhasznált oligonukleotidok az Szegedi Biológia Kutatóközpontban készültek vagy az Integrated DNA Technologies cégtől származnak. Az oligonukleotidok szekvenciája, rövid leírása és felhasználása a 3. táblázatban látható.

\begin{tabular}{|c|c|c|c|}
\hline Név & Szekvencia (5'-3' irány) & Tulajdonság & Felhasználás \\
\hline AK240 & GAATGAACTGCAGGACGAGG & $\begin{array}{l}\text { A pUP41 171- } \\
\text { 190bp szakasza }\end{array}$ & \multirow{2}{*}{$\begin{array}{l}\text { A SmaI }_{279} \text { hely } \\
\text { szekvenálására } \\
\text { használt } \\
\text { primerek }\end{array}$} \\
\hline AK241 & AGTACGTGCTCGCTCGATGC & $\begin{array}{l}\text { A pUP41 438- } \\
\text { 419bp } \\
\text { komplementer } \\
\text { szakasza }\end{array}$ & \\
\hline AK244 & CTAGATCTGCCCGGGCAGAT & $\begin{array}{l}\text { Önmagával } \\
\text { részlegesen } \\
\text { komplementer, } \\
\text { tartalmaz egy } \\
\text { SmaI helyet }\end{array}$ & $\begin{array}{l}\text { SmaI hely } \\
\text { beépítése a } \\
\text { pACYC- } \\
\text { M.PspGI } \\
\text { plazmidba }\end{array}$ \\
\hline AK245 & CATGTAACTCGCCTTGATCG & $\begin{array}{l}\text { A pUP41 } 2275- \\
\text { 2294bp szakasza }\end{array}$ & \multirow{2}{*}{$\begin{array}{l}\text { A BcnI }{ }_{2411} \text { hely } \\
\text { szekvenálására } \\
\text { használt } \\
\text { primerek }\end{array}$} \\
\hline AK246 & ACGCTCACCGGCTCCAGATT & $\begin{array}{l}\text { A pUP41 2523- } \\
2504 \mathrm{bp} \\
\text { komplementer } \\
\text { szakasza }\end{array}$ & \\
\hline AK252 & TAATTGTTGCCGGGAGGCCAGAGTAAG & \multirow{2}{*}{$\begin{array}{l}\text { AK254 és AK255 } \\
\text { oligokkal } \\
\text { képeznek duplexet }\end{array}$} & \multirow{4}{*}{$\begin{array}{l}\text { A BcnI hely } \\
\text { hasításának } \\
\text { tesztelésére } \\
\text { használt } \\
\text { oligonukleotid } \\
\text { duplexek }\end{array}$} \\
\hline AK253 & TAATTGTTGC $5^{\mathrm{m}}$ CGGGAGGCCAGAGTAAG & & \\
\hline AK254 & TTTCTTACTCTGGCCTCCCGGCAACAATTA & \multirow{2}{*}{$\begin{array}{l}\text { AK252 és AK253 } \\
\text { oligokkal } \\
\text { képeznek duplexet }\end{array}$} & \\
\hline AK255 & TTTCTTACTCTGGCCTCC $5^{\mathrm{m}}$ CGGCAACAATTA & & \\
\hline AK233 & GTA TTT GAA GCT T́T GCT GGA ATT GG & $\begin{array}{l}\text { A pBHNS-M.SssI } \\
\text { plazmid 651- } \\
\text { 676bp szakasza }\end{array}$ & $\begin{array}{l}\text { F17S } \\
\text { aminosavcsere } \\
\text { létrehozására } \\
\text { használt mutagén } \\
\text { primer }\end{array}$ \\
\hline AK234 & $\begin{array}{l}\text { GAA GCT TTT GCT GAC ATT GGT GCT CAA } \\
\text { AG }\end{array}$ & $\begin{array}{l}\text { A pBHNS-M.SssI } \\
\text { plazmid } 657- \\
685 \mathrm{bp} \text { szakasza }\end{array}$ & $\begin{array}{l}\text { G19D } \\
\text { aminosavcsere } \\
\text { létrehozására } \\
\text { használt mutagén } \\
\text { primer }\end{array}$ \\
\hline
\end{tabular}

3. táblázat. Felhasznált oligonukleotidok és jellemzőik. 


\section{Kompetens sejt készítés és transzformáció}

Az E. coli sejtek transzformálását a Lederberg és Cohen által kidolgozott $\mathrm{CaCl}_{2}$-os módszerrel végeztük (Lederberg és Cohen, 1974). A kémiailag kompetenssé tett sejteket a plazmid DNS-sel fél órán át jégen inkubáltuk, majd $42^{\circ} \mathrm{C}$-on tartottuk 1,5 percig. A hőkezelés után a sejteket $1 \mathrm{ml}$ LB tápoldatban 1 órán keresztül a transzformálandó plazmid replikációs rendszerének megfelelő hőmérsékleten $\left(30^{\circ} \mathrm{C}\right.$ vagy $\left.37^{\circ} \mathrm{C}\right)$ rázattuk, majd $150 \mu 1$ kultúrát megfelelő antibiotikum tartalmú LB lemezre szélesztettünk.

A dezaminációs kísérletek során, nagyobb transzformálási hatékonyság elérésének érdekében elektroporálást alkalmaztunk, amihez a kompetens sejteket standard protokoll alapján készítettük (Sambrook és Russell, 2006). A DNS hozzáadása után a kompetens sejtek elektrosokkolását a Bio-Rad cég MicroPulser készülékével végeztük, $0,1 \mathrm{~cm}$ elektródavastagságú küvettákban, $1,8 \mathrm{kV}$ maximális feszültségen. Ezután a sejteket $1 \mathrm{ml}$ SOC tápoldatban egy órán át rázattuk a megfelelö hőmérsékleten, végül a kultúra egy részét a megfelelő antibiotikumot tartalmazó LB lemezre szélesztettük.

\section{Fehérjetisztítás}

A C-terminális hisztidin jelöléssel ellátott WT és mutáns M.SssI fehérjéket $E$. coli ER1821 vagy DH10B sejtekből tisztítottuk. A módszer eredeti leírását lásd (Rathert és mtsai., 2007). A pBHNS túltermelő vektorba klónozott gének kifejeződését minden esetben L-arabinózzal indukáltuk. A sejteket TB tápoldatban növesztettük $37^{\circ} \mathrm{C}$-on, majd $\mathrm{OD}_{600} \approx 0,4$ sürüségnél $0,1 \%$ L-arabinóz hozzáadásával indukáltuk a metiltranszferáz termelését. A baktériumkultúrát további 4-6 órán át növesztettük $30^{\circ} \mathrm{C}$-on, majd a sejteket centrifugáltuk, szuszpendáltuk 50mM Tris- $\mathrm{HCl} \quad(\mathrm{pH}=8), 1 \mathrm{mM}$ EDTA, 10mM $\beta$ merkaptoetanol és 5\% glicerin tartalmú pufferben és ultrahangos kezeléssel feltártuk. A homogenizátumot centrifugáltuk (30 perc $16000 \mathrm{rpm}$ ) és a sejtörmelékmentes felülúszót a feltáráshoz használt pufferben kétszeresre hígítva heparin-agaróz oszlopon folyattuk át. Az oszlophoz kötődött fehérjéket $0-1 \mathrm{M} \mathrm{NaCl}$ grádienssel $(50 \mathrm{mM}$ Tris- $\mathrm{HCl} \mathrm{pH}=8$ és $5 \%$ glicerin tartalmú pufferben) eluáltuk, majd a frakciókat SDS-poliakrilamid gélen vizsgáltuk. A legtöbb MTázt tartalmazó frakciókat összegyüjtöttük és ekvilibráló pufferben (50mM Tris- $\mathrm{HCl} \mathrm{pH}=7,5,0,5 \mathrm{M} \mathrm{NaCl}$ és $1 \mathrm{mM}$ imidazol) kétszeresre hígítva az előbb leírt pufferrel egyensúlyba hozott Ni-agaróz oszlopra (His-Select, Sigma) vittük. A fehérjét $50 \mathrm{mM}$ Tris- $\mathrm{HCl}(\mathrm{pH}=7,5), 0,5 \mathrm{M} \mathrm{NaCl}$, és $250 \mathrm{mM}$ imidazol tartalmú pufferrel mostuk le 
az oszlopról. Az SDS-poliakrilamid gélelektroforézissel ellenőrzött megfelelő frakciókat összegyüjtöttük és töményítő pufferrel szemben $(50 \mathrm{mM}$ Tris- $\mathrm{HCl} \mathrm{pH}=7,5,100 \mathrm{mM} \mathrm{NaCl}$, $1 \mathrm{mM}$ EDTA, 10mM $\beta$-merkaptoetanol, 50\% glicerin) dializáltuk. A tisztított enzim mennyiségét Bradford reakcióval határoztuk meg az 595nm hullámhosszon mért optikai denzitása alapján (Bradford, 1976).

Egylépéses tisztítás esetén a sejteket az előbb leírt módon növesztettük, centrifugáltuk és ultrahangozás után $1 \mathrm{mM}$ imidazol tartalmú ekvilibráló pufferben kétszeresre hígítva egyenesen Ni-agaróz oszlopra vittük. A tisztítás további lépései az előzőekhez hasonlóan történtek.

\section{Az F17S és G19D mutáns M.SssI enzimek létrehozása helyspecifikus mutagenezissel}

Az SssI metiltranszferáz SAM kötő motívumában található szubsztitúciókat a Kunkel-féle irányított mutagenezissel hoztuk létre (Kunkel, 1985). Ennek során a célszekvenciát tartalmazó, fágmid alapú, pBSss-16 plazmiddal transzformált E. coli K1053 sejteket $100 \mu \mathrm{g} / \mathrm{ml}$ ampicillin és $0,25 \mu \mathrm{g} / \mathrm{ml}$ uridin jelenlétében LB tápoldatban növesztettük. A gazdasejtekből hiányzik a D-uracil-trifoszfatáz (Dut) és az uracil-DNS glikoziláz (Ung) enzim, aminek következtében a plazmid replikáció során a DNS-be timin helyett uracil fog beépülni. $\mathrm{OD}_{600} \approx 0,15$ sürüségnél a baktériumkultúrát ötvenszeres multiplicitás mellett R176 fággal fertőztük, hogy egyszálú fágmid DNS képződjön. További 5 óra rázatás után a sejteket centrifugálással $\left(8000 \mathrm{rpm}, 15\right.$ perc, $\left.4^{\circ} \mathrm{C}\right)$ ülepítettük és a felülúszóban található fágrészecskékből egyszálú DNS-t tisztítottunk. Ehhez $23 \mathrm{ml}$ felülúszóhoz 4,6 $\mathrm{ml}$ 20\% PEG és $2,5 \mathrm{M} \mathrm{NaCl}$ tartalmú oldatot adtunk és 1 órát állni hagytuk jégen. A kicsapódott fágrészecskéket lecentrifugáltuk ( $8000 \mathrm{rpm}, 30$ perc, $\left.4^{\circ} \mathrm{C}\right)$, majd a csapadékot szuszpendáltuk 0,4 $\mathrm{ml}$ TE pufferben. Az egyszálú DNS-t fenolkloroformos extrakció után etanollal csaptuk ki és TE pufferben oldottuk fel.

A komplementer DNS szál in vitro szintéziséhez a T4 polinukleotid kinázzal foszforilált, megfelelő mutációt hordozó AK233 vagy AK234 oligonukleotidot és az uracilt tartalmazó egyszálú fágmid DNS-t $90-95^{\circ} \mathrm{C}$-on 5 percig inkubáltuk, majd hagytuk lehűlni szobahőmérsékletre. A második szál szintézise a kapott uracilos DNS templát/primer felhasználásával $50 \mathrm{mM} \mathrm{NaCl}, 500 \mu \mathrm{M}$ dNTP mix, $1 \mathrm{mM}$ ATP, 5 egység T4 DNS polimeráz és 5 egység T4 DNS ligáz felhasználásával 40mM Tris- $\mathrm{HCl}(\mathrm{pH}=5)$, $10 \mathrm{mM} \mathrm{MgCl} 2,1 \mathrm{mM}$ DTT és $0,1 \mathrm{mg} / \mathrm{ml}$ BSA tartalmú pufferben történt. A reakció $4^{\circ} \mathrm{C}$-ról 
indult majd 5 perc szobahőmérsékleten való inkubálás után 2,5 órán át tartott $37^{\circ} \mathrm{C}$-on. Szintézis után a DNS-t XLBlue MRF' $d u t^{+} u n g^{+}$sejtekbe transzformáltuk, amelyben csak a mutációt hordozó szál replikálódik, a templátként használt uracilos szál lebomlik. A megfelelő klónokat szekvencia meghatározással azonosítottuk. Végezetül az sssIM gén vad típusú, vagy megfelelő mutációt tartalmazó BamHI-SacI fragmentumát a pBSss-16 alapú plazmidból a pSTdC- illetve pBHNS- alapú plazmidok megfelelő helyeire klónoztuk további felhasználás céljából.

\section{M.SssI fehérjevariánsok kifejeződésének ellenőrzése immunoblottal}

A mutáns illetve vad típusú M.SssI fehérje kifejeződését ER1821 sejtekben, pBHNS- alapú plazmidokról immunoblot technikával is megvizsgáltuk. A sejteket $20 \mathrm{ml}$ LB/Ap tápoldatban növesztettük $30^{\circ} \mathrm{C}$-on, $0,1 \%$ L-arabinóz jelenlétében. 4 órás indukció után a sejteket centrifugáltuk, és ultrahangos kezeléssel feltártuk a fehérje tisztításnál leírt feltáró pufferben. A sejtmentes kivonatban levő fehérjéket 5 perc $95^{\circ} \mathrm{C}$-on történő inkubálással denaturáltuk. Az analízist általános Western-blot protokoll alapján végeztük (Sambrook és Russell, 2006). Röviden: SDS-poliakrilamid gélelektroforézis után a fehérjéket PVDF (Millipore) membránra vittük át $(30$ perc, $10 \mathrm{~V}, 60 \mathrm{~mA}$, félszáraz blottoló). A szabadon maradt fehérjekötő felület blokkolását 1\% kazein (Novagen) tartalmú oldattal végeztük. A 6xHis-farokra specifikus elsődleges ellenanyagot (His-Tag Monoclonal Antibody, Novagen) 1000-szeres hígításban használtuk, a kötés $4^{\circ} \mathrm{C}$-on, éjszakán át történt. A nem kötődött ellenanyag eltávolításához a membránt mostuk kétszer 10 percen át $20 \mathrm{ml}$ TBSTT majd 10 percen át $15 \mathrm{ml}$ TBS oldatban. A másodlagos, tormaperoxidázzal („Horseradish Peroxidase”, HRP) konjugált ellenanyagot a blokkoláshoz is használt oldatban 15000-szeres hígításban használtuk. A membránt egy órán át inkubáltuk az oldatban, majd újra mostuk ötször (10 perc, 20ml TBSTT). Az immunreakciót kemilumineszcenciás eljárással (Chemiluminescent Peroxidase Substrate-3, Sigma), röntgenfilmen detektáltuk.

\section{Metiltranszferáz aktivitás mérése}

\section{Trícium beépülésén alapuló metiltranszferáz aktivitás mérés}

A vad típusú vagy mutáns M.SssI variánsok metiltranszferáz aktivitásának méréséhez 10ng/ $\mu 1 \quad \lambda$ DNS-t változó koncentrációjú tisztított enzimmel vagy nyers sejtkivonattal inkubáltunk MTáz reakciópufferben $(50 \mathrm{mM}$ Tris- $\mathrm{HCl} \mathrm{pH}=8,5,50 \mathrm{mM} \mathrm{NaCl}$, 
$10 \mathrm{mM}$ DTT), $250 \mu \mathrm{g} / \mathrm{ml}$ BSA és $5 \mu \mathrm{M}$ [metil- $\left.{ }^{3} \mathrm{H}\right]-\mathrm{SAM}$ jelenlétében. 20 perc $30^{\circ} \mathrm{C}$-on történő inkubáció után a reakciót 1,3\% SDS hozzáadásával állítottuk le és a reakcióelegyet DE81 (Whatman) papírkorongra pipettáztuk. A korongokat mostuk háromszor 50mM $\mathrm{Na}_{2} \mathrm{HPO}_{4}$ oldatban és kétszer 95\%-os etanollal, majd megszárítottuk. A beépült ${ }^{3} \mathrm{H}$ aktivitást folyadékszcintillációs készülékkel mértük meg.

\section{Védési teszt}

Az SssI metiltranszferáz variánsok félkvantitatív mérésére úgynevezett védési tesztet használtunk. In vitro aktivitás meghatározásához az enzimeket különböző koncentrációban 10-25 ng/ $\mu 1$ plazmid vagy $\lambda$ DNS-el inkubáltunk MTáz reakció pufferben $30^{\circ} \mathrm{C}$-on fél órán át. A reakciót egyes esetekben 20 perces $60^{\circ} \mathrm{C}$-os hőinaktiválással, máskor 0,5\% SDS hozzáadásával állítottuk le. Ez utóbbi esetben a DNS-t fenolkloroformos extrakció után etanollal kicsaptuk, és TE pufferben oldottuk fel. In vivo aktivitás meghatározása esetén pBHNS-M.SssI, pBHNS-M.SssI(F17S) vagy pBHNSM.SssI(G19D) plazmidokkal transzformált sejtekben 0,1\% L-arabinóz hozzáadásával indukáltuk az enzimtermelést, majd 4, 6 illetve 8 óra után a $30^{\circ} \mathrm{C}$-on növesztett kultúrákból plazmidot izoláltunk.

$\mathrm{Az}$ in vitro kezelt DNS-t, vagy a tenyészetekből izolált plazmidokat Hin6I restrikciós enzimmel emésztettük majd az emésztett DNS-t 1\%-os agaróz gélen vizsgáltuk. A Hin6I általi hasítás gátolt, ha a felismerési helyben, GCGC, az aláhúzott citozin metilált.

\section{Metiltranszferáz aktivitás in vivo vizsgálata McrBC restrikciós emésztéssel szembeni érzékenység alapján}

Az enzimvariánsok metiltranszferáz aktivitásának in vivo vizsgálatához a megfelelő pBHNS- alapú plazmidot tartalmazó DH5ג $m c r B C^{+}$és DH10B $m c r B C$ sejteket $20 \mathrm{ml}$ $\mathrm{LB} / \mathrm{Ap}$ tápoldatban növesztettük $30^{\circ} \mathrm{C}$-on. $\mathrm{OD}_{600} \approx 0,3-0,4$ sürüségnél $0,1 \%$ L-arabinóz hozzáadással indukáltuk az enzimtermelést, majd meghatározott időközönként megmértük a kultúra optikai denzitását. Az McrBC endonukleáz hasítja a $(\mathrm{G} / \mathrm{A})^{\mathrm{m} 5} \mathrm{C}$ szekvenciákat tartalmazó DNS-t.

\section{CG-specifikusan metilált DNS preparátumok előállítása}

Gélböl izolált DNS fragmentumok illetve a pUP41 plazmid DNS in vitro CGmetilációját $30^{\circ} \mathrm{C}$-on végeztük, tisztított M.SssI felhasználásával. A reakcióelegy 1-5 $\mu \mathrm{g}$ 
DNS-t, MTáz puffert (50mM Tris- $\mathrm{HCl} \mathrm{pH}=8,5,10 \mathrm{mM}$ EDTA, 50mM NaCl, 10mM DTT), $0,16 \mathrm{mM}$ SAM-ot, $350 \mu \mathrm{g} / \mathrm{ml}$ BSA-t valamint változó mennyiségű enzimet tartalmazott. A 30 perces vagy 1 órás inkubációt követően a reakciót 0,5\% SDS hozzáadásával állítottuk le, majd a DNS-t fenol-kloroformos extrakcióval tisztítottuk, etanollal kicsaptuk és TE pufferben oldottuk fel.

A pUP41 plazmid CG helyeinek in vivo metilációjához DH10B sejteket transzformáltunk pUP41 és pSTC-M.SssI plazmidokkal. $\mathrm{Az} \quad \mathrm{Ap}^{\mathrm{R}} \mathrm{Cm}^{\mathrm{R}}$ kettős transzformánsokból plazmid DNS-t tisztítottunk, amihez a sejteket $30^{\circ} \mathrm{C}$-on növesztettük 0,1\% L-arabinóz jelenlétében. A tisztított plazmid metiláltságát Hin6I restrikciós emésztéssel ellenőriztük.

\section{In vitro dezamináció}

$\mathrm{A} \mathrm{C} \rightarrow \mathrm{U}$ illetve ${ }^{\mathrm{m} 5} \mathrm{C} \rightarrow \mathrm{T}$ dezamináció kimutatására egy antibiotikum-rezisztencia reverzióján alapuló, Bhagwat és csoportja (Beletskii és Bhagwat, 2001) által kidolgozott módszert alkalmaztunk. A vizsgálathoz felhasznált pUP41 plazmid a Tn5 transzpozonból származó kanamicin-rezisztencia gén egy mutáns allélját (kanS-H94) tartalmazza, amelyben a Leu94Pro szubsztitúció kanamicin szenzitív fenotípust eredményez. A mutáns kodon egy SmaI restrikciós enzim felismerési helyben (CCㅡ/GGG) található. Az aláhúzással jelzett citozin timinre cserélődése visszaállítja az eredeti Leu94 kodont és az antibiotikum rezisztenciát. Mivel az aláhúzással jelzett citozin része az SssI metiltranszferáz felismerési helyének (CG), a pUP41 felhasználható szubsztrátként az M.SssI által katalizált citozin dezamináció vizsgálatára. A citozin dezaminációja következtében uracil, és így hibás U:G bázispár jön létre, amely ha javítatlan marad, végül $\mathrm{C} \rightarrow \mathrm{T}$ mutáció megjelenését eredményezi a DNS replikáció során. Ez a citozin-timin csere ugyanakkor az adott SmaI hely eltünését, és egy új BstNI (MvaI), azaz CC/WGG felismerési hely megjelenését eredményezi, ami egyszerü emésztéssel és agaróz gélelektroforézissel kimutatható (4. ábra). A pUP41 plazmid összesen 534 CG dinukleotidot tartalmaz. 


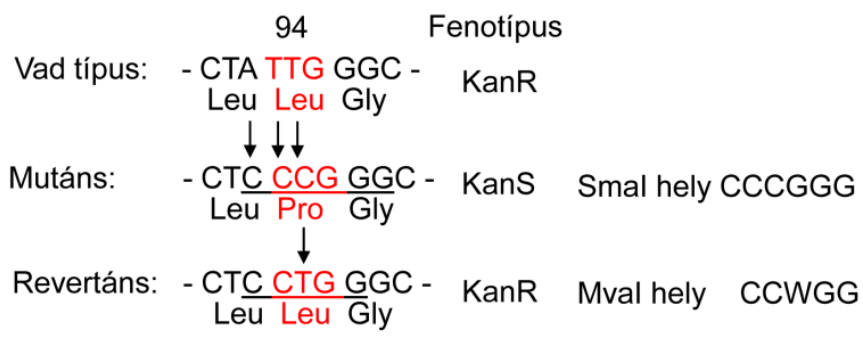

4. ábra: A $\mathbf{C} \rightarrow \mathbf{T}$ mutáció kimutatására szolgáló reverziós teszt elve. A nyilak a pUP41 kanamicinrezisztencia génjében található nukleotid módosításokat jelölik. A 94. kodon pirossal kiemelve látható.

A pUP41 plazmidot (70-110ng) tisztított vad típusú vagy mutáns M.SssI enzimmel inkubáltunk $30^{\circ} \mathrm{C}$-on 4 órát. A reakció $50 \mathrm{mM}$ Tris- $\mathrm{HCl}(\mathrm{pH}=8,5), 10 \mathrm{mM}$ EDTA, $50 \mathrm{mM}$ $\mathrm{NaCl}, 10 \mathrm{mM}$ DTT tartalmú MTáz reakciópufferben, $350 \mu \mathrm{g} / \mathrm{ml}$ BSA jelenlétében zajlott. Ilyen körülmények közt a reakcióban $0,18-0,27 \mu \mathrm{M}$ CG-hely volt, az enzim koncentrációja pedig kísérlettől függően változott. A vizsgálni kívánt hatástól függően a reakcióelegyhez $160 \mu \mathrm{M}$ SAM-ot vagy váltózó mennyiségü szinefungint (SF) illetve 5'-amino-5'dezoxiadenozint (AA) is adtunk. A dezaminációs reakciót minden esetben 0,5\% SDS-el állítottuk le. A fenol-kloroformos extrakcióval tisztított, etanollal kicsapott DNS-t TE pufferben oldottuk fel és E. coli ER2357 ung vagy DH10B ung ${ }^{+}$gazdába juttattuk elektroporálással. A baktérium kultúrát megfelelő hígításban Ap illetve Kn tartalmú táplemezre szélesztettük és a revertáns illetve összes transzformált sejt arányából reverziós gyakoriságot számoltunk. 5-metilcitozin dezamináció vizsgálata esetén az előzőekben leírt módon előállított in vivo metilált pUP41 plazmidot használtunk szubsztrátként és a kezelt DNS-t E. coli DH10B ung ${ }^{+}$gazdába transzformálva állapítottuk meg a reverzió gyakoriságát. Az uracil-DNS glikoziláz müködése révén kiszürhető az esetlegesen metilálatlanul maradt citozinok dezaminációja, így a $\mathrm{C} \rightarrow \mathrm{U} \rightarrow \mathrm{T}$ útvonalon keresztül megjelenő revertánsok nem torzítják az eredményt.

\section{In vivo dezamináció}

\section{A reverzió gyakoriságának mérése (egyszerű in vivo dezaminációs teszt)}

Az egyszerübb in vivo mérés során a pUP41 és pSTdC-M.SssI (WT), (F17S) vagy (G19D) plazmidokat tartalmazó kettős transzformánsokból starter kultúrát készítettünk $0,2 \%$ glukóz jelenlétében. A sejteket kiülepítettük, mostuk, majd egy részüket $20 \mathrm{ml}$, friss Ap és $\mathrm{Cm}$ tartalmú $\mathrm{LB}$ tápoldatba oltva tovább tenyésztettük $30^{\circ} \mathrm{C}$-on. $\mathrm{OD}_{600} \approx 0,2$ 
sűrüségnél $0,1 \%$ L-arabinóz hozzáadásával indukáltuk a metiltranszferáz termelést. További 24 óra növesztés után $1 \mathrm{ml}$ kultúrából a sejteket kiülepítettük és reszuszpendáltunk $200 \mu 1$ friss LB tápoldatban. Ebből $100 \mu 1-\mathrm{t}$ Kn tartalmú, a többit pedig megfelelő hígításban Ap tartalmú táplemezre szélesztettünk és az előbbiekben leírt módon reverziós gyakoriságot számoltunk.

Abban az esetben, amikor a célszekvenciát tartalmazó kanS (kanS-H94) allél a gazdasejtek kromoszómáján volt, a megfelelő metiltranszferáz variáns kifejeződése a pBHNS- alapú plazmidokról történt. A reverzió gyakoriságának mérését az előbbihez hasonlóan végeztük 4 órás $0,1 \%$ L-arabinóz indukció után.

\section{Mutációs ráta mérése (fluktuációs teszt)}

A dezaminációs rátát kanamicin-rezisztens revertánsok megjelenésének gyakoriságán alapuló fluktuációs analízissel vizsgáltuk (Luria és Delbruck, 1943; Rosche és Foster, 2000), pUP41 és pSTdC- alapú, két plazmidot tartalmazó rendszert használva. A méréshez starter kultúrát készítettünk 20ml Ap és Cm tartalmú LB tápoldatban, amelyben a metiltranszferáz termelését $0,2 \%$ glukóz hozzáadásával represszáltuk. A baktérium kultúrát glukóz nélküli tápoldatban reszuszpendáltuk és $\sim 10^{5}$ sejtet átoltottunk 10 párhuzamos, $1 \mathrm{ml}$ 0,1\% L-arabinózzal és megfelelő antibiotikummal kiegészített LB tápoldatba. A kultúrákat $30^{\circ} \mathrm{C}$-on növesztettük a stacioner fázis eléréséig majd minden csőből a kultúra felét Kn tartalmú táptalajra szélesztettük a revertánsok számának meghatározásához. Az összsejtszámot 2-2, véletlenszerüen kiválasztott csőből vett minták hígításainak Ap tartalmú táptalajra való szélesztésével határoztuk meg. A kapott telepszámokból a reverziós rátát az on-line elérhető FALCOR program segítségével számoltuk ki, a Ma-Sandri-Sarkar maximum-likelihood (MSS-MLL) eljárással (Hall és mtsai., 2009).

\section{Oligonukleotidok és DNS fragmentumok radioaktív jelölése}

Az oligonukleotid duplexek radioaktív jelöléséhez a megfelelő, komplementer, egyszálú oligonukleotid párokat (AK252 és AK254 illetve AK253 és AK255) 80C-ra melegítettük, majd 50mM Tris- $\mathrm{HCl}(\mathrm{pH}=7,5), 0,9 \mathrm{M} \mathrm{NaCl}$ tartalmú pufferben 1 órán át inkubáltuk $53^{\circ} \mathrm{C}$-on. Az AK254 és AK255 oligonukleotidok egy 5'-TTT túlnyúló véget tartalmaznak, ami lehetővé tette a létrehozott kettősszálú DNS jelölését Klenow-polimeráz általi feltöltéssel, $\left[\alpha-{ }^{32} \mathrm{P}\right]$-dATP felhasználásával. A reakciót a gyártó utasításait követve 
végeztük. A DNS duplexek minden esetben a G közepü szálon tartalmazták a radioaktív jelzést. Az AK252/254 duplex módosítatlan, míg az AK253/254 és AK252/255 duplexek módosított (egyik szálon C5-metilációt hordozó) BcnI helyeket tartalmaznak. Az AK253/255 duplex esetén a BcnI hely mindkét szálon módosított citozint tartalmaz. A pUC18 plazmid AvaII-SspI 441bp-os fragmentumának radioaktív jelölését $\left[\alpha-{ }^{32} \mathrm{P}\right]$-dCTP és Klenow polimeráz felhasználásával végeztük, a gyártó utasításait követve. A beépült ${ }^{32} \mathrm{P}$ aktivitást folyadékszcintillációs készülékkel, Cserenkov sugárzás alapján mértük.

\section{Jelölt DNS minták MvaI emésztésének vizsgálata}

Annak megállapítására, hogy a BcnI hely milyen mértékủ metilációja (C-szál, Gszál vagy mindkettő) szükséges a szubsztráthely MvaI általi hasításához, az elöbbiekben leírt radioaktívan jelölt kettősszálú oligonukleotidokat vagy a pUC18-ból származó DNS fragmentumot használtuk fel. A megfelelő minták MvaI emésztését a gyártó által javasolt körülmények közt végeztük ( $\mathrm{R}$ puffer, $37^{\circ} \mathrm{C}$ ). Az emésztési elegyek minden esetben tartalmaztak $0,5 \mu \mathrm{g}$ pUC18 plazmidot is, így a kanonikus helyek hasításának mértékét agaróz gélen ellenőrizni tudtuk. A radioaktívan jelölt DNS emésztési termékeit 7M urea tartalmú 6\%- vagy 10\%-os poliakrilamid gélen vizsgáltuk és autoradiográfiával vagy phosphor-image analízissel tettük láthatóvá általános protokollt követve (Sambrook és Russell, 2006).

\section{Egyéb anyagok, enzimek és módszerek}

Az MvaI restrikciós enzim (hagyományos és Fast Digest) a Fermentas/Thermo Scientific illetve Sigma cégektől származik. A munka során használt restrikciós enzimeket, T4-DNS ligázt, E. coli DNS polimeráz I-et, és a DNS polimeráz I Klenow-fragmentjét a Fermentas/Thermo Scientific, az S-adenozil-L-metionint (SAM) pedig a New England Biolabs cégektől szereztük be. Az enzimekkel végzett reakciókat a gyártó javaslatát követve állítottuk össze. A $\left[\alpha^{32} \mathrm{P}\right]$-dATP és $\left[\alpha^{32} \mathrm{P}\right]$-dCTP az Izotóp Intézet Kft. (Budapest), a [metil- $\left.{ }^{3} \mathrm{H}\right] \mathrm{SAM}$ az American Radiolabeled Chemicals, a szinefungin (SF) és 5'-amino-5'-dezoxiadenozin (AA) pedig az Eli Lilly vagy Sigma cégek termékei voltak.

A DNS klónozás, polimeráz láncreakció, szcintillációs mérések, valamint a DNS minták agaróz gélelektroforézise és fehérjék SDS-poliakrilamid gélelektroforézise általános protokoll alapján történt. A fehérjemintákat 10\%-os SDS-poliakrilamid gélen futtattuk és a Comassie Brilliant Blue festékkel tettük láthatóvá (Sambrook és Russell, 
2006). A DNS minták szekvenciameghatározása automatizált szekvenálókészülékkel (ABI) készült. A phosphor-image által alkotott kép kvantitatív elemzése az ImageQuant szoftverrel történt. A statisztikai elemzéseket a GraphPad Prism szoftverrel végeztük. 


\section{Eredmények}

\section{M.SssI által katalizált citozin és 5-metilcitozin dezamináció}

\section{M.SssI által katalizált in vitro citozin dezamináció}

$\mathrm{A} \mathrm{C} \rightarrow \mathrm{U}$ konverzió kimutatására egy kanamicin-rezisztencia reverzióján alapuló tesztet alkalmaztunk. Az M.SssI általi dezamináció optimális körülményeinek meghatározásához a mutáns rezisztencia gént tartalmazó pUP41 plazmid DNS-t tisztított M.SssI enzimmel inkubáltuk a metildonor, SAM hiányában, különböző enzim/CG (szubsztrát hely) moláris arányt használva. Figyelembe véve csoportunk M.SssI-el kapott eddigi eredményeit miszerint a metiltranszferáz aktivitás mind in vivo mind in vitro $30^{\circ} \mathrm{C}$ on magasabb, mint $37^{\circ} \mathrm{C}$-on, és feltételezve, hogy az enzim által katalizált dezamináció is hasonló hőmérsékleti optimummal rendelkezik, kísérleteinket általában $30^{\circ} \mathrm{C}$-on végeztük. Az M.SssI-el inkubált pUP41 DNS-t uracil-DNS glikoziláz hiányos E. coli ER2357 ung sejtekbe elektroporáltuk, hogy elkerüljük a keletkező uracilok kijavítását. A reverzió gyakoriságát a kanamicin és ampicillin rezisztens kolóniák arányából állapítottuk meg. A legtöbb kanamicin-rezisztens kolóniát kétszeres enzim/CG arány esetén kaptuk. Ilyen enzimmennyiségnél a revertánsok gyakorisága időfüggő növekedést mutatott. Ez a növekedés 4 óra után már nem volt olyan számottevő, nagy valószínűséggel az enzim csökkenő aktivitása miatt, így a további kísérleteknél a kétszeres enzim/CG hely arányt és 4 órás inkubációt alkalmaztunk. Ilyen körülmények közt az M.SssI nélkül inkubált plazmidok esetén $10^{-5}-10^{-4}$ körüli reverzió frekvencia értékeket kaptunk, amihez képest az enzim jelenléte tízszeres növekedést eredményezett. A vártnak megfelelően SAM jelenlétében a reverzió a spontán értékre csökkent (5. ábra/A). A metiltranszferázzal kezelt plazmidok E. coli $\mathrm{DH10B}$ ung $^{+}$gazdába való transzformálása esetén a revertánsok gyakorisága nem mutatott számottevő növekedést 8 órás M.SssI inkubálás után sem, jelezvén, hogy a kanamicin-rezisztens fenotípus megjelenése valóban a $C \rightarrow U \rightarrow T$ útvonalon keresztül történik (5. ábra/B). 
A

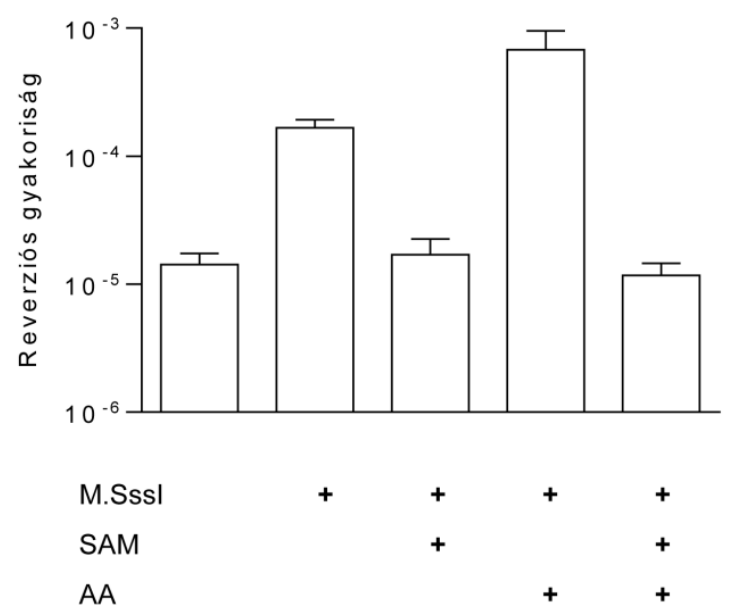

B

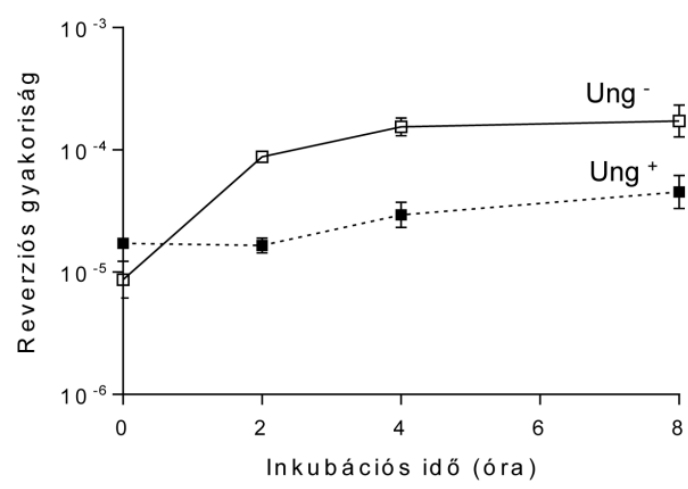

5. ábra. M.SssI által katalizált citozin dezamináció in vitro. (A) A kanamicin-rezisztencia reverzió gyakoriságának változása kétszeres M.SssI/CG arány esetén SAM $(160 \mu \mathrm{M})$ illetve AA $(500 \mu \mathrm{M})-$ lásd később - jelenlétében és hiányában. A hibavonalak legalább három független mérés átlagának standard hibáját jelölik. Varianciaanalízissel $\mathrm{p}<0,01$ szintű szignifikanciát határoztunk meg. (B) A kanamicinrezisztencia reverzió gyakoriságának változása M.SssI-el való inkubációs idő függvényében ER2357 ung $\left(\mathrm{Ung}^{-}\right)$és DH10B ung $^{+}\left(\mathrm{Ung}^{+}\right)$gazdákban. A hibavonalak három független mérés átlagának standard hibáját jelölik.

A pUP41 plazmid két SmaI és 13 MvaI (BstNI) felismerési helyet tartalmaz. Az egyik SmaI (CCC/GGG) hely eltünése és egy új MvaI (CC/WGG) hely megjelenése az aláhúzással jelzett citozin timinre cserélődését jelzi. Egyes kanamicin-rezisztens kolóniákból plazmidot izoláltunk és a várt nukleotid cserét jelző SmaI hely eltünését és egy új MvaI hely megjelenését restrikciós emésztéssel is ki tudtuk mutatni (6. ábra).

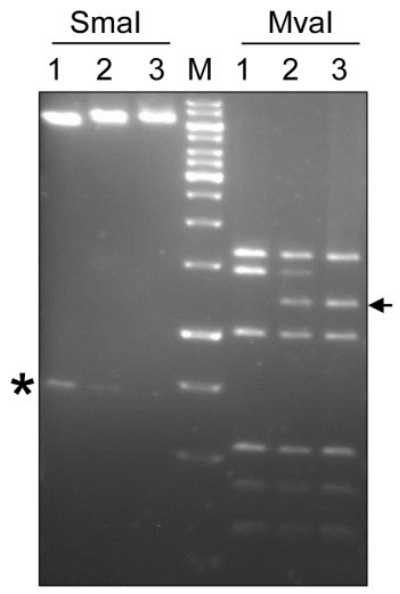

6. ábra. A dezamináció során kialakuló $\mathrm{C} \rightarrow \mathrm{U}$ és ${ }^{\mathrm{m} 5} \mathrm{C} \rightarrow \mathrm{T}$ szekvencia változások kimutatása restrikciós emésztéssel. $\mathrm{Az}$ ábrán különböző $\mathrm{Kn}^{\mathrm{R}}$ kolóniákból izolált revertáns plazmidok SmaI illetve MvaI emésztésének agaróz gélelektroforézise látható. 1 - kezeletlen pUP41, 2 - metilálatlan pUP41 szubsztráttal kapott revertáns plazmid, 3 - CG-metilált szubsztráttal kapott revertáns plazmid, csillag - eltünő SmaI fragmentum, nyíl megjelenő MvaI fragmentum. A 2. minta esetén megfigyelhető halványabb fragmentumok, amelyek a kezeletlen minta fragmentumaival együtt vándorolnak, a nem teljes plazmidszegregáció miatt megjelenő, vegyes plazmid populációra utalnak. 


\section{M.SssI variánsok in vivo metiltranszferáz aktivitásának jellemzése}

A metiltranszferázokra általánosan jellemző, FxGxG szekvenciájú, I. konzervált motívum a SAM kötő zseb részét képezi (Cheng és mtsai., 1993; Kumar és mtsai., 1994; Reinisch és mtsai., 1995). Az M.SssI által katalizált citozin dezamináció in vivo tanulmányozásához a Shen és munkatársai által létrehozott, csökkent SAM kötő aktivitással rendelkező F38S és G40D M.HpaII (Shen és mtsai., 1995) variánsokhoz hasonló M.SssI mutánsokat hoztunk létre. A HpaII metiltranszferáz F38 és G40 aminosavai az előbbiekben említett szekvenciamotívum részét képezik és az SssI MTáz esetén az F17 és G19 aminosavaknak felelnek meg (7. ábra).

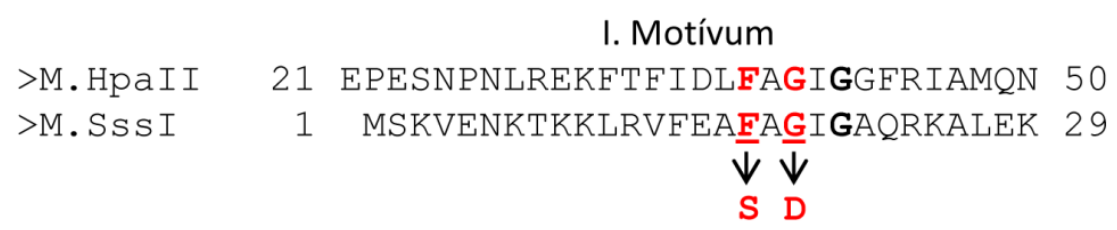

7. ábra. A HpaII és az SssI metiltranszferázok aminosavszekvenciájának egy részlete kiemelve a konzervált FxGxG motívumot. Pirossal az F38/F17S és a G40/G19D szubsztitúciók láthatóak.

Az M.SssI F17S és G19D aminosavcseréit helyspecifikus mutagenezissel hoztuk létre majd az sssIM gén mutáns és vad alléljait két különböző típusú plazmidra klónoztuk: a pSTdC- plazmidokat a pUP41-el való kotranszformáláshoz és in vivo kísérletekhez használtuk, a pBHNS- plazmidokat pedig túltermelő vektorként az M.SssI tisztításhoz. A metiltranszferáz kifejeződés és ennek szabályozhatósága SDS-poliakrilamid gélen és pBHNS- alapú plazmidok esetén immunoblot analízissel is kimutatható volt (8. ábra). 
A

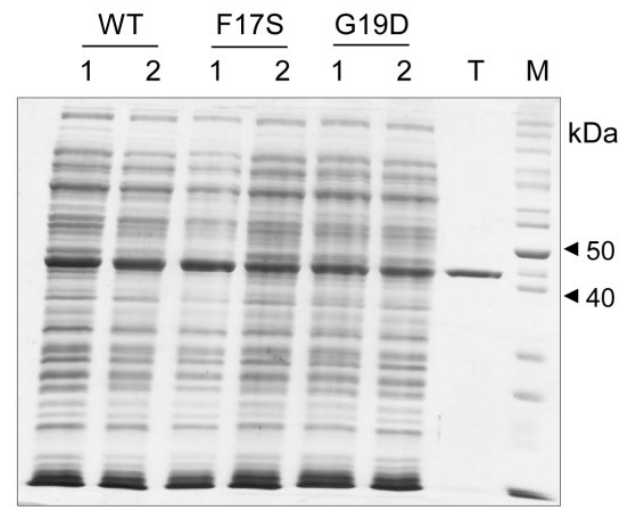

B

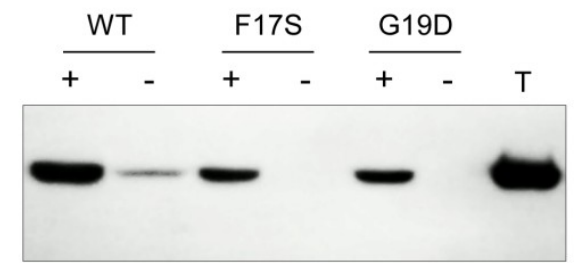

8. ábra. M.SssI WT, F17S és G19D enzimek termelésének kimutatása. (A) A különböző enzimvariánsok kimutatása nyers sejtkivonatból, SDS-poliakrilamid gélelektroforézissel. 1 - pBHNS- alapú, 2 - pSTdCalapú plazmidról kifejezett fehérje, T - tisztított M.SssI, M- fehérje mólsúly marker. (B) pBHNS-alapú plazmidokról történő fehérje kifejeződés szabályozhatóságának kimutatása immunoblot analízissel. Az enzimek jelenlétét nyers sejtkivonatból, a 6xHis-farokra specifikus ellenanyag felhasználásával vizsgáltuk. + 0,1\% L-arabinózzal indukált, - 0,2\% glukózzal represszált minta. T - tisztított M.SssI.

Az F17S és G19D mutánsok metiltranszferáz aktivitását különböző hosszúságú indukció után izolált pBHNS-alapú plazmidokon vizsgáltuk. Az egyes plazmidok CGmetilációját a Hin6I restrikciós emésztéssel szembeni védettség alapján állapítottuk meg. 4 óra indukció után a WT MTázt kódoló plazmid már teljesen védett, míg az F17S és G19D mutánsokat kódoló plazmidok majdnem teljesen emészthetőek voltak. 6 és 8 óra indukció után a mutánsokat kódoló plazmidok esetén egyre több részleges emésztési termék jelent meg, ami a metiláció mértékének növekedését jelezte. A pBHNS-M.SssI(G19D) nagyobb védettséget mutatott Hin6I emésztéssel szemben, mint a pBHNS-M.SssI(F17S) (9. ábra/A). Ezekből az eredményekből arra következtettünk, hogy a két mutáció nagymértékű csökkenést eredményezett a metiltranszferáz aktivitásban, de nem vezetett teljes inaktivációhoz. A részleges aktivitást a mutáns metiltranszferázokat kifejező $\mathrm{McrBC}^{+}$és $\mathrm{McrBC}^{-}$gazdák eltérő életképessége is megerősítette. Az McrBC endonukleáz a $(\mathrm{G} / \mathrm{A}){ }^{\mathrm{m} 5} \mathrm{C}$ szekvenciákat ismeri fel és hasítja a DNS-t már az egyik szál metilációja esetén (Raleigh, 1992). Az M.SssI általi citozin metiláció számos McrBC felismerési helyet hoz létre a baktérium kromoszómáján, ami egy $\mathrm{McrBC}^{+}$gazdában DNS degradációhoz vezet. A mutáns metiltranszferázok kifejeződése a pBHNS- alapú plazmidokról $\mathrm{McrBC}^{+}$sejtekben növekedés gátláshoz vezetett, míg az $\mathrm{McrBC}^{-}$sejtek tovább nőttek (9. ábra/B). 
A

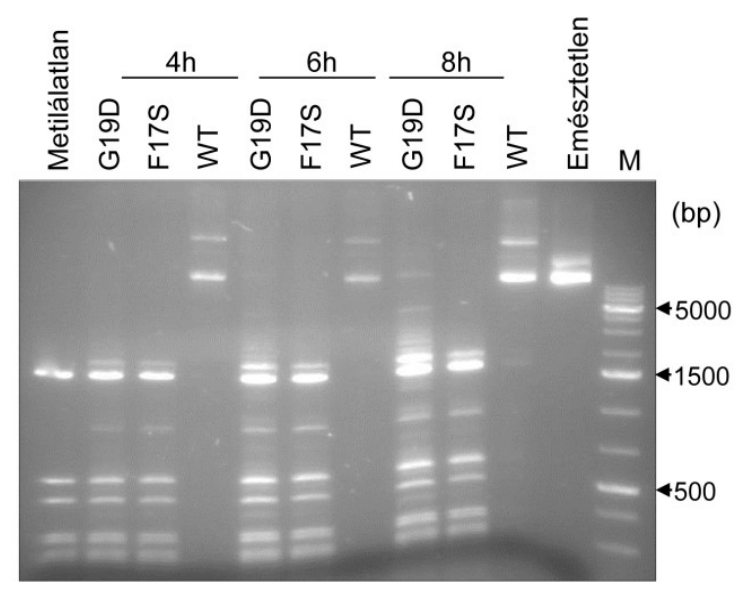

B

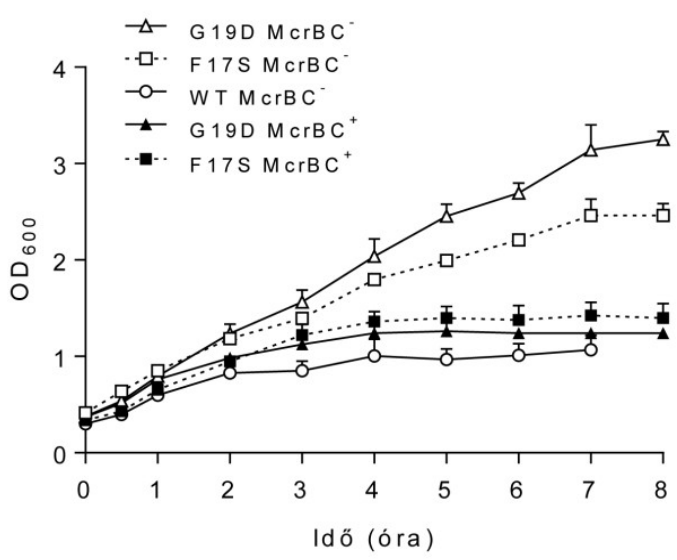

9. ábra. Az F17S és G19D mutáns M.SssI enzimek in vivo DNS metiltranszferáz aktivitása. (A) A képen a vad típusú illetve mutáns M.SssI variánsokat kódoló pBHNS-M.SssI, pBHNS-M.SssI(F17S), és pBHNSM.SssI(G19D) plazmidok Hin6I emésztésének agaróz gélelektroforézise látható 4, 6 illetve 8 órás arabinóz indukció után. Metilálatlan - glukózon növesztett (metiltranszferáz kifejeződésben gátolt) pBHNSM.SssI(G19D) plazmid Hin6I emésztése, Emésztetlen - Hin6I emésztés nélküli pBHNS-M.SssI plazmid, M - DNS marker. (B) A WT és mutáns M.SssI enzimek kifejeződésének hatása $\mathrm{McrBC}^{-}$és $\mathrm{McrBC}^{+}$sejtek növekedésére. Az enzimtermelést $0,1 \%$ L-arabinózzal indukáltuk. A növekedési görbe 0 pontja az indukció pillanatát jelenti. A hibavonalak három független mérés átlagának standard hibáját jelölik.

\section{M.SssI variánsok in vivo dezaminációs aktivitásának jellemzése}

A vad típusú illetve mutáns enzimvariánsok dezaminációs képességét in vivo eredetileg egy két plazmidot tartalmazó rendszerben teszteltük, amelyben a célszekvencia és a metiltranszferázok génjei is plazmidon találhatóak. Ebben a rendszerben az ER2357 ung és ER1821 ung $^{+}$sejteket pUP41 és a ColE1 replikonnal kompatibilis, pSTdCM.SssI(WT), (F17S) vagy (G19D) plazmidokkal transzformáltuk, majd a kettős transzformánsokat felhasználva 24 órás arabinóz indukció után meghatároztuk a reverzió mértékét. Ung gazdában megnövekedett reverziós gyakoriságot tapasztaltunk a G19D enzimvariáns esetén. A továbbiakban, hogy pontosabb képet kapjuk a citozin dezamináció gyakoriságáról, megvizsgáltuk a dezaminációt in vivo úgy is, hogy a célszekvencia, a mutáns kanamicin-rezisztencia gén, az ER2357-kanS ung és DH10B-kanS ung ${ }^{+}$ gazdasejtek kromoszómáján volt. Ez lehetőséget adott egyrészt arra, hogy a reverzió gyakoriságának megállapításánál kiszürjük a plazmidszegregációhoz kapcsolódó esetleges hibákat, másrészt a rendszer lehetővé tette a magas kópiaszámú pBHNS- alapú plazmidok használatát, ami az előbbi rendszerhez képest sokkal magasabb in vivo enzimkoncentrációt 
eredményez. A reverzió gyakoriságát ebben az esetben 4 órás arabinóz indukció után vizsgáltuk. A pBHNS plazmidot nem tartalmazó, tehát metiltranszferázt nem termelő sejtekkel mért reverziós gyakoriságot tekintettük az adott körülmények közt mért spontán citozin dezamináció gyakoriságának. Ez Ung gazda esetén $10^{-7}-10^{-8}$ körül volt, míg Ung ${ }^{+}$ gazdában ennél körülbelül egy nagyságrenddel alacsonyabb. A WT és F17S variánsok kifejeződése nem okozott számottevő változást, a G19D viszont tízszeres növekedést eredményezett a spontán dezaminációhoz képest mindkét gazdában (10. ábra/A)

Az előbbiekben leírt egyszerü reverziós teszttel a különböző M.SssI variánsok müködése következtében megjelenő mutációk gyakoriságát (vagy a reverzió frekvenciát) tudjuk megállapítani, ez azonban a mutációs rátáról nem ad pontos képet (Rosche és Foster, 2000). A dezaminációs ráta megállapításához a pUP41 és pSTdC- alapú, két plazmidot tartalmazó rendszert használva fluktuációs tesztet végeztünk. Az eredmények megerősítették az egyszerü reverziós tesztnél látottakat: Ung- gazdában az F17S mutáns csak kismértékü ( kétszeres) míg a G19D 11-szeres növekedést eredményezett a spontán dezaminációs rátához képest (10. ábra/B).

A

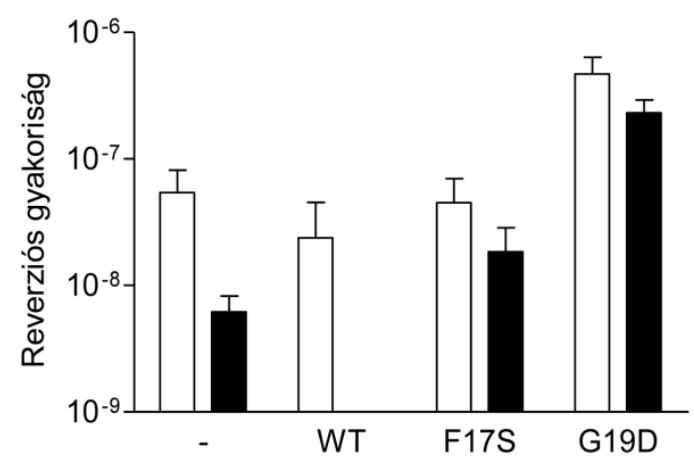

B

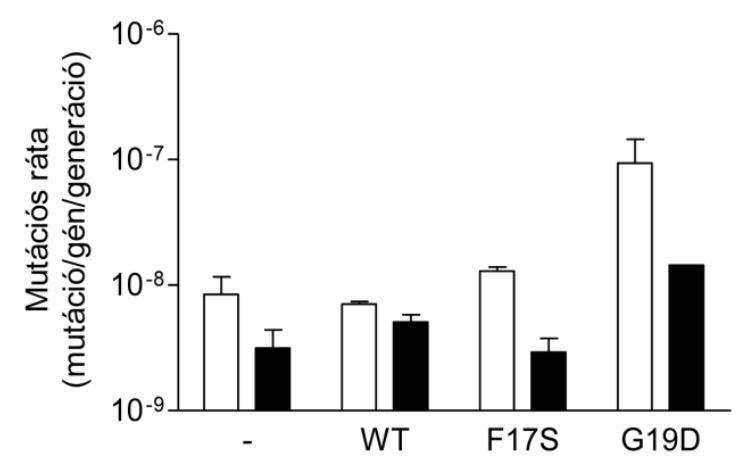

10. ábra. WT és mutáns M.SssI által katalizált dezamináció in vivo. (A) Különböző M.SssI variánsok hatása a kanamicin-rezisztencia reverzió gyakoriságára ER2357-kanS ung (fehér) és DH10B-kanS ung+ (fekete) gazdákban. A hibavonalak három független mérés átlagának standard hibáját jelölik. Varianciaanalízissel $p<0,01$ szintủ szignifikanciát állapítottunk meg. Az arabinóz indukció után bekövetkezö lassú növekedés miatt a WT enzimet kifejező DH10B-kanS gazda reverziós gyakorisága nem volt pontosan meghatározható, ezért ez az adat nem szerepel az ábrán. (B) Különböző M.SssI variánsokat kifejező ER2357 ung (fehér) és DH10B ung ${ }^{+}$(fekete) gazdák mutációs rátája. A méréseket a kanamicin-rezisztencia reverzióján alapuló fluktuációs teszttel végeztük. Független mérések száma: MTáz nélkül (3), WT és F17S (2), G19D (4). A hibavonalak a mérések átlagainak standard hibáját jelölik. 
Mindkét mérés esetén megfigyelhető volt a G19D által okozott dezaminációs gyakoriság, illetve mutációs ráta növekedése $\mathrm{Ung}^{+}$gazda esetén is, noha az Ung gazdában mérthez képest itt alacsonyabb értékeket kaptunk. A citozin dezamináció hasonló, nem várt növekedését figyelték meg a HpaII G40D variánsa esetén is. Ez valószínűleg annak tudható be, hogy a MTáz erősen kötődik a dezamináció során keletkező premutagén U:G bázispárhoz (erősebben, mint a kanonikus C:G párhoz) meggátolva az uracil-DNS glikoziláz hozzáférését az adott szekvenciához és a javítást (Shen és mtsai., 1995; Yang és mtsai., 1995).

\section{Az M.SssI variánsok in vitro metiltranszferáz aktivitásának jellemzése}

Az M.SssI enzimvariánsokat a pBHNS-alapú túltermelő vektor felhasználásával tisztítottuk az Anyagok és Módszerek fejezetben leírt módon heparin-agaróz és Ni-agaróz, vagy csak Ni-agaróz affinitáskromatográfiával. Az enzimpreparátumok tisztaságát SDS gél alapján becsültük meg. Ez két oszlopon való tisztítás esetén közel 100\%, ha csak Ni-agaróz oszlopot használtunk, enzimpreparátumtól függően, 60-80\% volt. A tiszta enzimek metiltranszferáz aktivitását védési teszttel hasonlítottuk össze, amely alátámasztotta az in vivo eredményeket: mindkét mutáns enzim számottevően alacsonyabb aktivitással rendelkezett, mint a vad típusú (11. ábra). Ezt a ${ }^{3} \mathrm{H}$ beépülésén alapuló mérések is megerösítették.

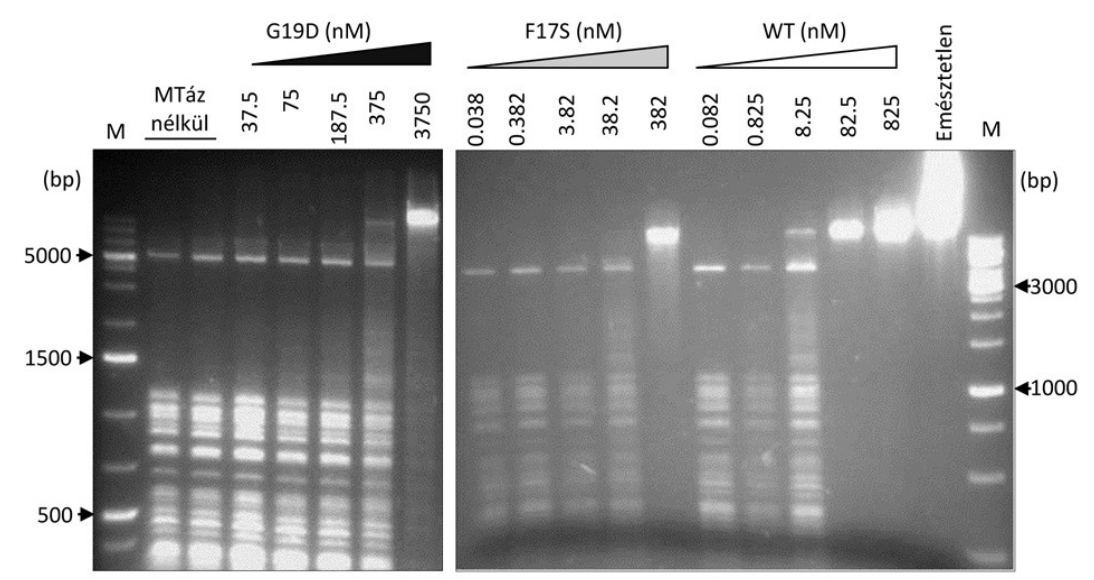

11. ábra. Tisztított F17S és G19D enzimek DNS-metiltranszferáz aktivitásának meghatározása védési teszttel. A képen különbözö koncentrációjú enzimpreparátumokkal SAM jelenlétében inkubált $\lambda$ DNS Hin6I emésztésének agaróz gélelektroforézise látható. MTáz nélkül - az első sávban kezeletlen $\lambda$ DNS preparátum, a második sávban metiltranszferáz nélkül inkubált $\lambda$ DNS Hin6I emésztése, Emésztetlen - Hin6I emésztés nélküli $\lambda$ DNS, M - DNS marker. 


\section{Az M.SssI variánsok in vitro dezaminációs aktivitásának jellemzése}

A tisztított enzimek citozin dezaminációs képességét in vitro a WT enzimmel végzett kísérlethez hasonló körülmények közt vizsgáltuk. SAM hiányában mindkét mutáns a vad típúshoz hasonló növekedést eredményezett a kanamicin-rezisztencia megjelenésének gyakoriságában.

A szinefungin (SF) és az 5'-amino-5'-dezoxiadenozin (AA) a metilációt gátló két SAM analóg, amelyekröl kimutatták, hogy több prokarióta metiltranszferáz citozin dezaminációs aktivitását is képesek nagymértékben megnövelni (Sharath és mtsai., 2000; Zingg és mtsai., 1996; Zingg és mtsai., 1998). Kíváncsiak voltunk, hogy hasonló hatás megfigyelhető-e az általunk előállított F17S és G19D mutáns esetén is. Az elöbbiekben leírt reverziós teszttel a SAM analógok koncentrációjának függvényében megvizsgáltuk a mutánsok általi citozin dezaminációt, és azt kaptuk, hogy a szinefungin $500 \mu \mathrm{M}$, az 5'amino-5'-dezoxiadenozin pedig $250 \mu \mathrm{M}$ koncentrációban a leghatékonyabb. Míg a SF hatása nem volt jelentős, az AA kb. egy nagyságrenddel növelte a reverzió gyakoriságát mindhárom enzimvariáns esetében. A legnagyobb reverziós gyakoriságot a WT $+\mathrm{AA}$ kombinációval figyeltük meg. A mutáns enzimekre gyakorolt gyengébb hatás nagy valószínüséggel a kofaktorhoz és ezáltal az analógokhoz való affinitás csökkenésével magyarázható. Az általunk használt körülmények közt $250 \mu \mathrm{M}$ AA mintegy húszszorosára növelte a WT enzim általi reverziós gyakoriságot, ami nagyjából nyolcvanszor nagyobb, mint az enzim hiányában mért spontán dezaminációs gyakoriság (12. ábra). SAM jelenléte eltörölte az AA hatását, és a reverziós gyakoriság a spontán értékre csökkent (5. ábra).

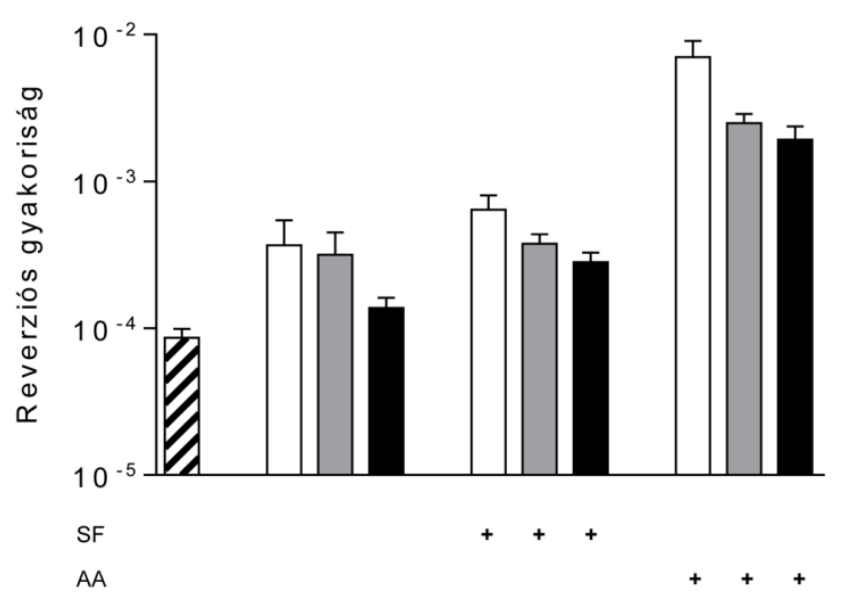

12. ábra. Szinefungin (SF) és 5'-amino-5'dezoxiadenozin (AA) hatása a vad típusú és mutáns M.SssI által katalizált citozin dezaminációra in vitro. A SF-t $500 \mu \mathrm{M}$, míg az AA-t $250 \mu \mathrm{M}$ koncentrációban használtuk. Csíkozott oszlop - enzim nélküli minta, fehér oszlop - WT, szürke oszlop - F17S, fekete oszlop - G19D. A hibavonalak 5 független mérés átlagának standard hibáját jelölik. Varianciaanalízissel $\mathrm{p}<0,01$ szintü szignifikanciát állapítottunk meg. 


\section{M.SssI által katalizált citozin és 5-metilcitozin dezamináció összehasonlítása}

A vad típusú M.SssI metilcitozin dezaminációs képességének vizsgálatához $\underline{\mathrm{C}} \mathrm{G}$ helyeken metilált pUP41 plazmidot használtunk szubsztrátként az in vitro reverziós tesztben. A kísérleti körülmények ugyanazok voltak, mint a metilálatlan citozin dezaminációjának vizsgálatakor, de ebben az esetben, hogy elkerüljük az esetlegesen metilálatlanul maradt citozinok dezaminációjának mérését, a reverzió gyakoriságát DH10B $u n g^{+}$sejtekben határoztuk meg. Az enzim nélkül mért spontán dezamináció metilált és metilálatlan plazmid esetén hasonló volt, így az Ung és $\mathrm{Ung}^{+}$gazdában mért reverzió direkt módon összehasonlítható. Míg a metilálatlan citozin esetén az enzim jelenléte mintegy tízszeres, AA és enzim együttes hatása pedig közel két nagyságrend növekedést eredményezett a spontán értékhez képest, a metilált plazmid esetén a reverzió gyakorisága nem változott számottevően egyik esetben sem (13. ábra).

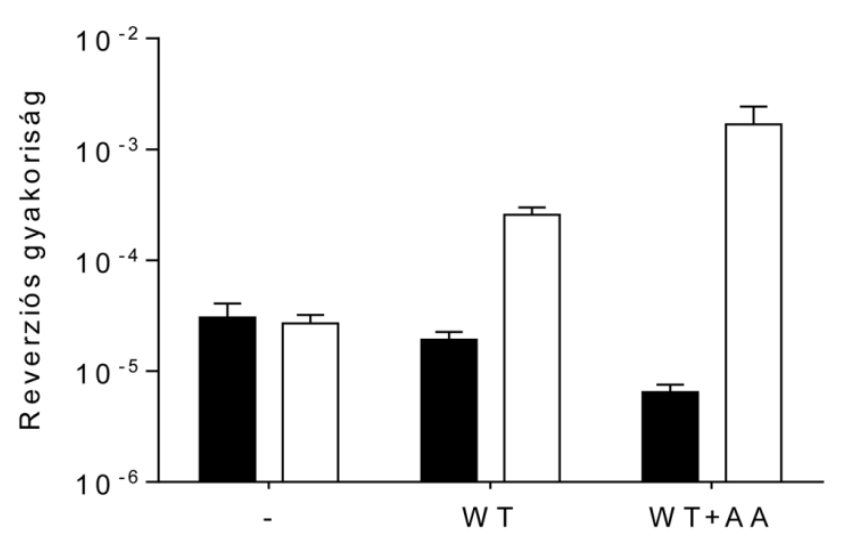

Ez ellentmondásban van a Métivier és munkatársai által közölt eredménnyel, akik a citozin illetve 5-metilcitozin dezaminációja során keletkező U:G illetve T:G hibás bázispárok megjelenését egy teljesen in vitro teszttel mérték. Abban a kísérleti rendszerben az M.SssI képes volt mind citozin, mind 5-metilcitozin dezaminációra, sőt ez utóbbi esetén mintegy 30\%-al magasabb dezaminációs rátát mértek, mint citozin esetén. Ráadásul $\mathrm{C} \rightarrow \mathrm{U}$ konverzió csak AA vagy SF jelenlétében, míg az ${ }^{\mathrm{m} 5} \mathrm{C} \rightarrow \mathrm{T}$ dezamináció a kofaktor analógok hiányában is kimutatható volt (Métivier és mtsai., 2008). A Métivier és csoportja által használt reakciókörülmények némileg eltértek az általunk használtaktól: ők $\mathrm{Mg}^{2+}$ tartalmú
13. ábra. M.SssI által katalizált citozin és 5metilcitozin dezamináció összehasonlítása. A reverziós gyakoriság meghatározása metilálatlan plazmid (fehér) $(\mathrm{C} \rightarrow \mathrm{U}$ konverzió) esetén ER2357 ung, metilált plazmid (fekete) $\left({ }^{\mathrm{m} 5} \mathrm{C} \rightarrow \mathrm{T}\right.$ konverzió) esetén pedig $\mathrm{DH} 10 \mathrm{~B}$ $u^{+}{ }^{+}$gazdában történt. A hibavonalak 3 független mérés átlagának standard hibáját jelölik. Varianciaanalízissel $\mathrm{p}<0,01$ szintü szignifikanciát állapítottunk meg. 
$\mathrm{pH}=7,5$ puffert, éjszakán át tartó inkubálást alkalmaztak és $37^{\circ} \mathrm{C}$-on vizsgálták az enzim dezaminációs képességét. A kapott eredmények közti ellentmondás feloldása végett megismételtük a kísérletet az általunk tisztított enzimmel $37^{\circ} \mathrm{C}$-on, 16 órás inkubálást és a Métivier és mtsai. által leírt puffert alkalmazva. Metilálatlan plazmid esetén a reverzió gyakorisága ebben az esetben is növekedést mutatott, a metilált plazmiddal azonban 16 óra inkubálás után is alacsonyabb reverziós értékeket kaptunk, mint az általunk általában alkalmazott kísérleti körülmények közt.

\section{M.SssI-specifikus metiláció következtében megjelenő új MvaI hasítási helyek}

A CG-specifikus M.SssI metiltranszferázzal végzett kísérleteink során azt vettük észre, hogy a pUP41 plazmid in vivo vagy in vitro M.SssI általi metilációja olyan fragmentumok megjelenését eredményezi a plazmid MvaI (CC/WGG) restrikciós enzimmel kapott emésztményében, amelyek metilálatlan DNS esetén nincsenek jelen. Az $\sim 1250$ bp és $\sim 454 \mathrm{bp}$ DNS fragmentumok megjelenése és az 1482bp fragmentum párhuzamos eltünése a $\mathrm{C} \rightarrow(\mathrm{U}) \rightarrow \mathrm{T}$ csere következtében létrejött revertáns állapotra jellemző, de mivel a megváltozott emésztési mintázat nem társult kanamicin rezisztens fenotípussal, nem tünt valószínűnek, hogy a várt mutáció bekövetkezett.

A megváltozott MvaI emésztési kép csak az M.SssI-el kezelt plazmidokra volt jellemző, amiből arra következtettünk, hogy ez a DNS metilációs állapotával lehet kapcsolatban. Ennek igazolására DH10B sejteket pUP41 és pSTC-M.SssI plazmidokkal transzformáltunk, majd a sejteket 4 órán át növesztettük L-arabinóz jelenlétében, hogy biztosítsuk a metiltranszferáz termelését és a pUP41 plazmid CG-metilációját. Ezután a sejtek egy részéből plazmidot izoláltunk, a többit pedig friss táptalajban $0,2 \%$ glukóz jelenlétében tovább növesztettük éjszakán át. Mivel glukóz jelenlétében a metiltranszferáz kifejeződése gátolt, a replikáció során keletkező újabb plazmidokat már nincs ami metilálja, ezért az így növesztett sejtekben levő DNS-ről gyakorlatilag teljesen letörölhető a metiláció.

Az így előállított plazmidok MvaI emésztéseit összehasonlítva azt kaptuk, hogy az új fragmentumok kizárólag az arabinózzal indukált kultúrából származó plazmidra jellemzőek, glukóz represszió és a metiláció letörlését követően visszaáll az ismert pUP41 MvaI emésztési mintázat. Ugyanezen plazmid preparátumok BstNI (egy MvaI izoszkizomer) emésztményében nem észleltünk semmilyen változást (14. ábra/A). 
Mindebből azt a következtetést vontuk le, hogy a CG-metiláció új, az MvaI-re specifikus hasítási helyek megjelenését eredményezi.
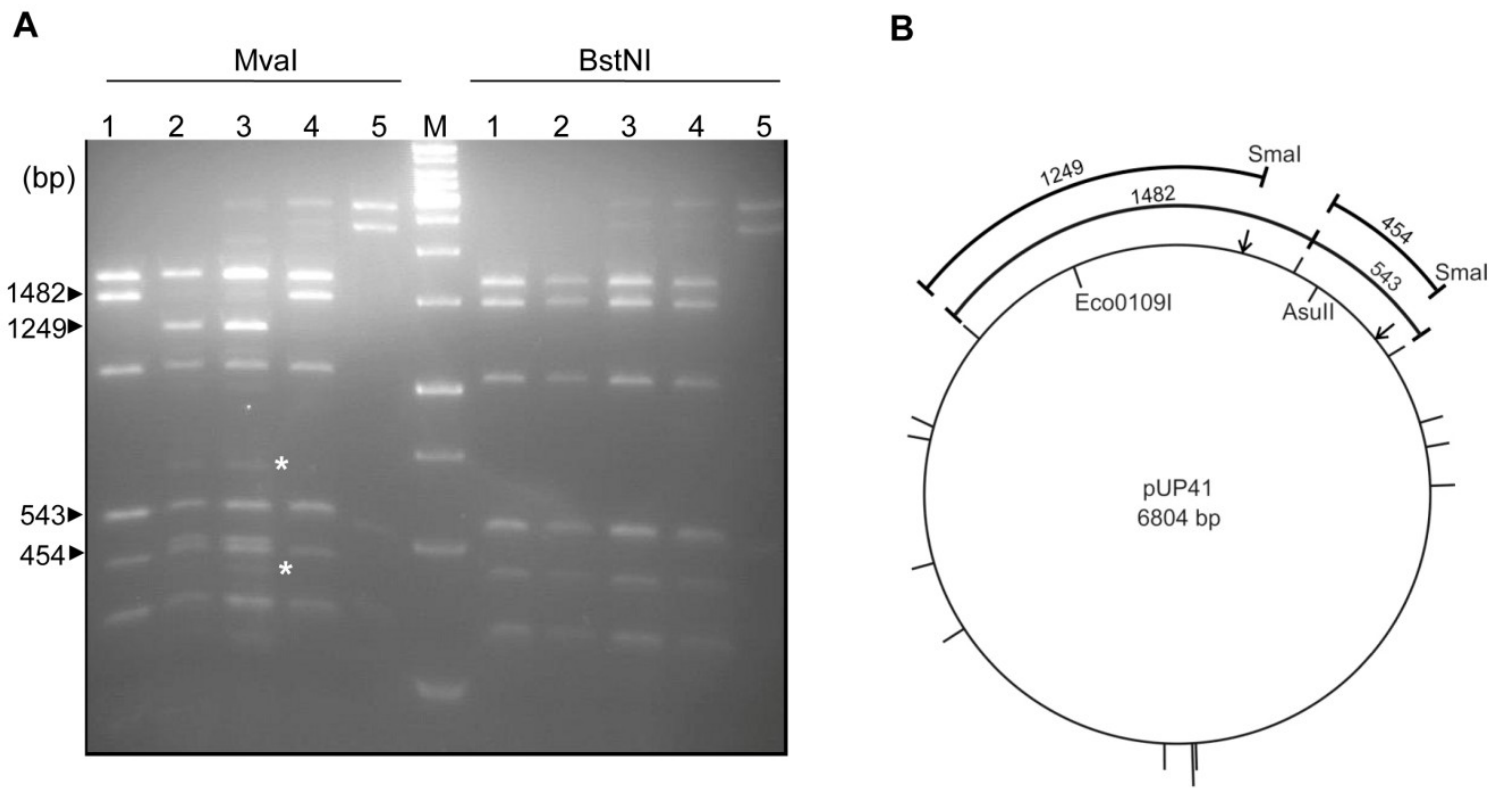

14. ábra. Metiláció-függő új MvaI hasítási helyek. (A) M.SssI metilált pUP41 plazmid MvaI illetve BstNI emésztésének agaróz gélelektroforézise. 1 - metilálatlan pUP41, 2 - M.SssI-el in vitro metilált pUP41, 3 - Larabinózzal indukált sejtekből tisztított (M.SssI-el in vivo metilált) pUP41, 4 - a metiláció letörléséhez glukózzal represszált sejtekből tisztított pUP41, 5 - indukálatlan sejtekből izolált pSTC-M.SssI plazmid. A gélkép mellett azon fragmentumok mérete van feltüntetve, amelyek a metilált illetve metilálatlan plazmid emésztményében eltérőek. Az 543bp fragmentum a metilált plazmid emésztményében is látható, mert együtt vándorol egy 540bp fragmentummal. Csillaggal vannak jelölve a metilált plazmid MvaI emésztése során szub-sztöchiometrikus mennyiségben megjelenő extra fragmentumok - lásd később. (B) A pUP41 MvaI (kiszögellések) és SmaI (nyilak) helyeket és a hasítások során keletkezö releváns fragmentumokat feltüntető restrikciós térképe.

\section{A metiláció-függő kettősszálú felismerési hely jellemzése}

Restrikciós térképezéssel sikerült kideríteni, hogy az új, metiláció-függő felismerési helyek egybeesnek vagy átfednek a pUP41-en található két SmaI (CCCGGG) hellyel (14. ábra/B). Erre további bizonyítékot a PspGI metiltranszferáz génjét hordozó, pACYC184M.PspGI(S) plazmid MvaI emésztése szolgáltatott. A PspGI metiltranszferáz a CCWGG helyek egyik citozinját metilálja ezáltal gátolva a kanonikus helyek MvaI általi hasítását. Az egyetlen SmaI helyet tartalmazó plazmidot csak abban az esetben sikerült MvaI-el 
linearizálnunk, ha ezt M.SssI által előzőleg in vitro metiláltuk. A metilálatlan plazmid védett volt az MvaI emésztéssel szemben (15. ábra).

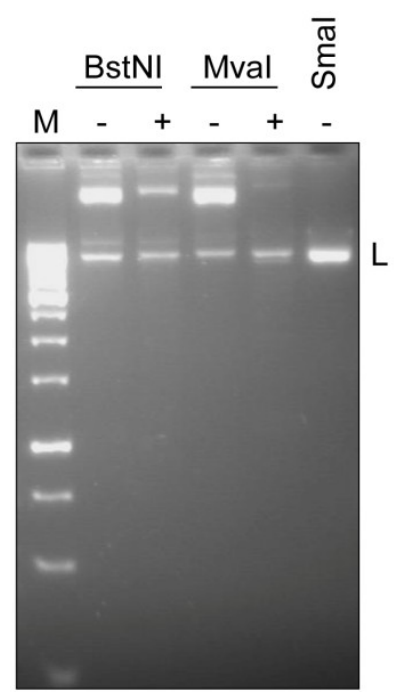

15. ábra. Metiláció-függő MvaI hasítás M.PspGI által védett CCWGG helyeken. A képen a pACYC184-M.PspGI(S) plazmid MvaI, BstNI és SmaI emésztésének agaróz gélelektroforézise látható. A - és + a plazmid M.SssI általi metilációjára utal. L - linearizált plazmid, M - DNS marker.

A hasítás pontos helyének meghatározásához a pUP41 SmaI ${ }_{279}$ helyét tartalmazó, EcoO109I-AsuII (1243bp) fragmentumot (14. ábra/B) metiláltuk M.SssI-el in vitro, MvaI enzimmel emésztettük és az emésztményt templátként használva szekvenciameghatározást végeztünk a SmaI hely irányába. Az úgynevezett „run-off” reakcióban a szekvenálási jel hirtelen csökkenése egy bázis után, a DNS fragmentum végét, vagyis a hasítás helyét jelöli. Az emésztetlen fragmentumot használva kontrollként azt kaptuk, hogy a DNS fragmentum mindkét szála hasadt a SmaI helynél (CCCGGG), mégpedig a harmadik (vagyis metilált) citozin és a guanin közt (16. ábra). Ez az eredmény alátámasztotta elképzelésünket, miszerint a metiláció-függő MvaI hasítás a SmaI helynél történik, és tompa végeket eredményez. 

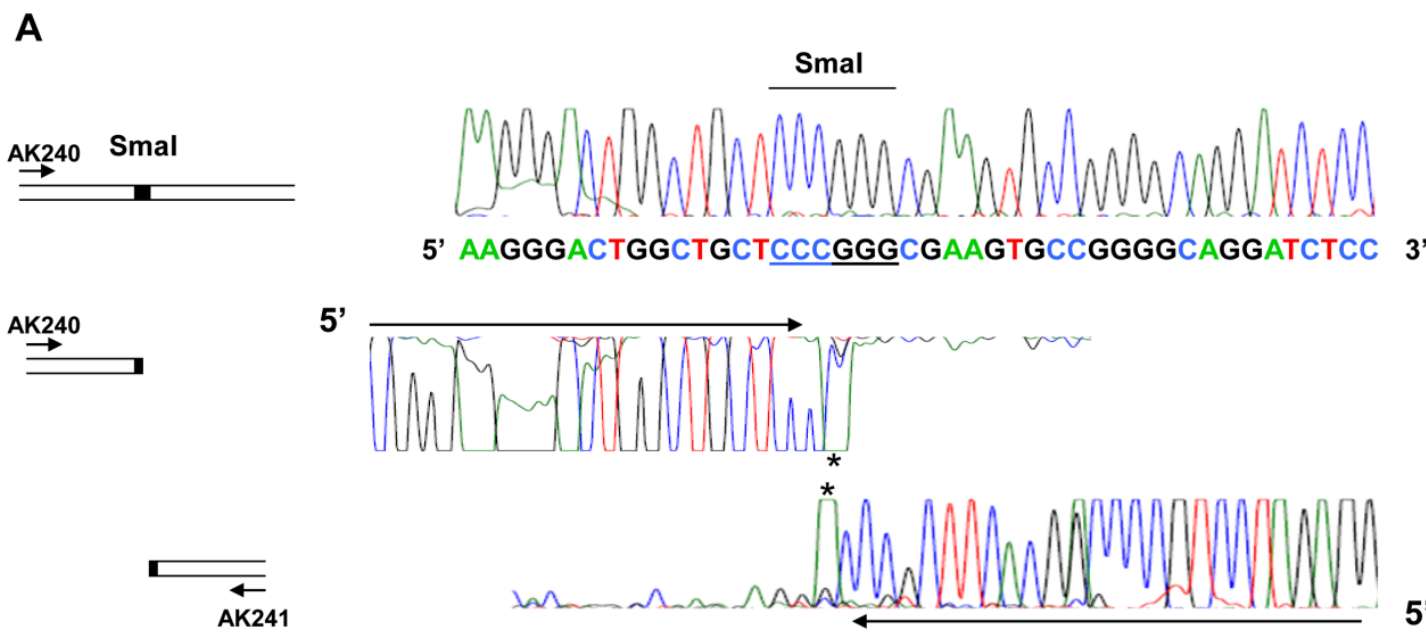

AK241

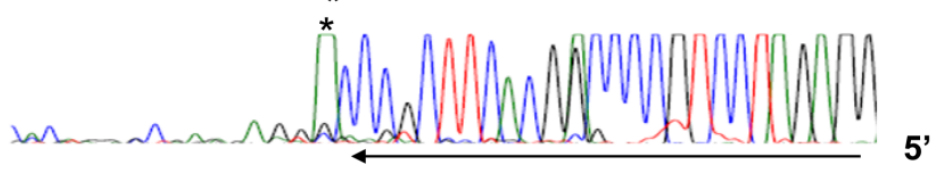

B

\begin{tabular}{ll|l|ll} 
C & C & A & G & G \\
G & G & T & C & C
\end{tabular}

kanonikus
C $\quad$ C $\stackrel{5 m}{C} \mid G \quad G \quad G$

G G G $\underset{\text { WG }}{\mathbf{C}}$ C C

M.SssI-metilált Smal hely

16. ábra. MvaI hasítás az M.SssI-specifikusan metilált SmaI helyeknél. (A) A szekvenciameghatározás eredménye metilált pUP41 SmaI 279 helynél intakt illetve MvaI-el emésztett fragmentumon. A bal oldali séma a szekvenálás irányát és felhasznált primereket mutatja. (B) MvaI hasítás a kanonikus és a metilált SmaI felismerési helyeken. Az emésztett DNS-fragmentum mindkét szálának 3'- végén megfigyelhető adenin (csillag), a szekvenciameghatározásnál használt Taq-polimeráz nem-templátspecifikus müködésének eredménye (Clark, 1988).

\section{A metiláció-függő kettősszálú hasítás jellemzése}

Az M.SssI metilált pUP41 plazmid MvaI emésztése során a SmaI helyek hasításából származó $1250 b p$ és 450bp fragmentumok mellett néhány halványabb DNS fragmentum is megjelenik a gélképen, amelyek hosszantartó emésztéssel erősebbé válnak. Ezek a fragmentumok valószínúleg a $\mathrm{CC}^{\mathrm{m} 5} \mathrm{CGGT}$ helyek hasításából keletkező részleges emésztési termékek (14. ábra/A csillaggal jelölve). Mivel teljes emésztést nem tudtunk elérni, tovább nem vizsgáltuk e szekvenciák MvaI hasítását, de megjelenésük az emésztményben mindenképpen arra utal, hogy a metiláció-függő MvaI hasítás kevésbé specifikus, mint az enzim kanonikus aktivitása (17. ábra). 


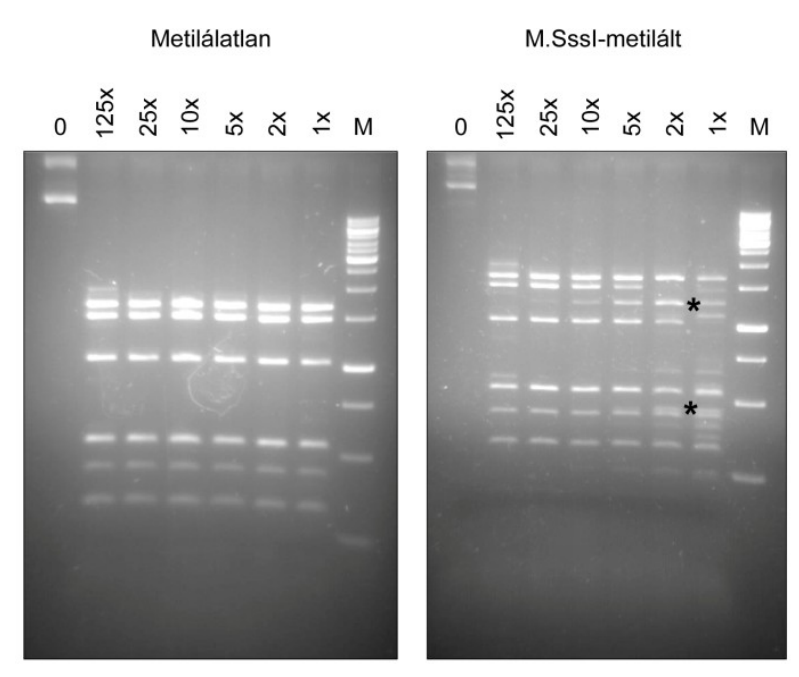

17. ábra. A kanonikus és a metiláció-függő MvaI hasítás specificitása. A képen metilálatlan és M.SssI-specifikusan metilált pUP41 plazmid MvaI emésztésének agaróz gélelektroforézise látható. A gélképek fölötti számok a kereskedelmi enzimpreparátum hígítását jelölik. A csillagok az aláhúzással jelzett citozinnál metilált SmaI (CCCGGGG) helyek emésztéséből származó 1249bp és 454bp fragmentumokat jelölik. A metilált plazmid 1x MvaI emésztményében megjelenő többi halvány fragmentum a csökkent specificitást jelzi.

A kanonikus és a metiláció-függő aktivitás sebességeinek összehasonlításához in vitro M.SssI-el metilált pUP41 plazmidot különböző koncentrációjú MvaI enzimmel emésztettük. Adott körülmények közt mintegy tízszer több enzimre volt szükség a metilált SmaI helyek teljes emésztéséhez (18. ábra). Hasonló vagy valamivel nagyobb különbségeket figyeltünk meg abban az esetben is, ha a SmaI hely más szekvenciakörnyezetben volt.

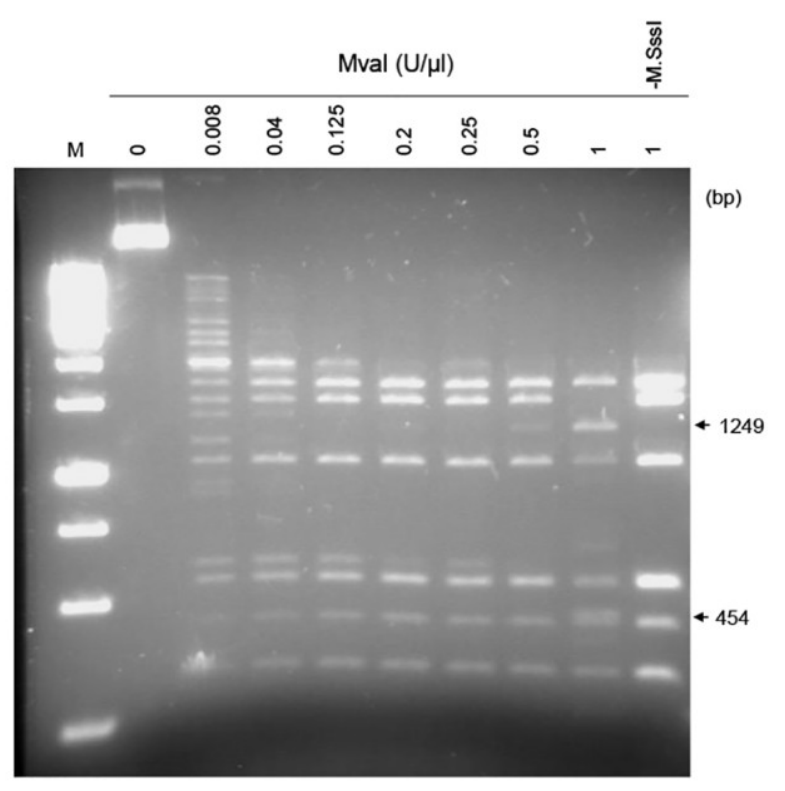

18. ábra. A kanonikus CCWGG és M.SssImetilált SmaI (CC ${ }^{\mathrm{m} 5}$ CGGG) helyek MvaI hasítási sebességeinek összehasonlítása. A képen M.SssI-el in vitro metilált pUP41 plazmid MvaI emésztésének agaróz gélelektroforézise látható. M - DNS marker, -M.SssI metilálatlan pUP41. AZ 1249bp és 454bp fragmentumok megjelenése a pUP41 két metilált SmaI helyének emésztését jelölik. 
Olyan plazmidok esetén, ahol a SmaI hely részleges átfedésben van egy BspRI (GGCC) hellyel, nem sikerült emésztést elérni (19. ábra), ami arra enged következtetni, hogy az átfedő BspRI metiláció (CCCGGG ${ }^{\mathrm{m} 5} \mathrm{CC} / \mathrm{GG}^{\mathrm{m} 5} \mathrm{CCCGGG)}$ gátolja a CGspecifikusan metilált SmaI helyek MvaI emésztését.

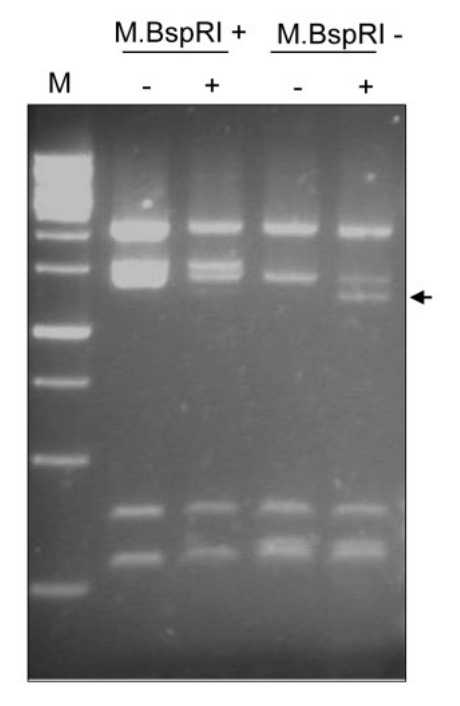

19. ábra. Metiláció-függő MvaI hasítás átfedő M.BspRI helyeknél. A képen a M.BspRI génjét tartalmazó pTZ-Bsp5 (M.BspRI +) és az inaktivált MTáz gént tartalmazó pTZ-BspDX (M.BspRI -) plazmidok MvaI emésztésének agaróz gélelektroforézise látható. A - és + jelölések az M.SssI-specifikus metilációt jelölik, M - DNS marker. A nyíl a metiláció-függő MvaI hasítás következtében megjelenő fragmentumot jelöli. Ez csak BspRI metiláció hiányában figyelhető meg.

Hogy kizárjuk annak lehetőségét, hogy az észlelt új MvaI aktivitás a Fermentas/Thermo Scientific-től kapott preparátumban levő szennyező enzimaktivitás eredménye, a metiláció-függő hasítóhelyek emésztését más forgalmazótól származó enzimmel is leellenőriztük. Ezt a Sigma cégtől származó MvaI preparátummal is ki tudtuk mutatni.

\section{M.SssI által metilált $\mathrm{C}^{\mathrm{m} 5} \mathrm{CSGG}(\mathrm{BcnI})$ helyek egyszálú hasítása}

Az MvaI egy monomer, amely szubsztrát szekvenciáját aszimmetrikusan ismeri fel, és a DNS kettősszálat két egyszálú hasítás, vagy nick révén vágja, 5'- túlnyúló véget eredményezve (Butkus és mtsai., 1985; Kaus-Drobek és mtsai., 2007; Kubareva és mtsai., 1991). Eddigi eredményeink azt mutatták, hogy ugyanez az enzim képes egy másik, hat nukleotidból álló, speciálisan metilált palindróm szekvenciát is felismerni, de ebben az esetben a hasítás tompa végeket eredményez. Annak ellenére, hogy a két szekvencia mutat némi hasonlóságot az eltérő hasítási mód valószerütlennek tünt, hisz ez a II. típusú restrikciós enzimek egy szigorúan meghatározott jellemzője. A metiláció-függő aktivitás célhelyeként azonosított SmaI hely nukleotidszekvenciája egy alternatív magyarázattal szolgált. A CCCGGG SmaI hely tulajdonképpen tartalmaz két, egymással részben átfedő 
és ellentétes irányú BcnI (CCSGG, S lehet C vagy $\mathrm{G}$ ) helyet, amelyek csak a középső nukleotidpárban térnek el a kanonikus MvaI felismerési helytől. Ez alapján azt a hipotézist vetettük fel, hogy az MvaI valójában a metilált BcnI helyeket ismeri fel, de csak az egyik szálon hasítja, azaz nickeli a DNS-t. Ez esetben a SmaI helynél tapasztalt kettősszálú DNS hasítás valójában az átfedő BcnI helyek kettős nickelésének az eredménye és az új szubsztráthelyek hasításának mechanizmusa nagyjából ugyanaz, mint a kanonikus helyek esetén. Az MvaI monomerikus volta lehetőséget ad a DNS nickelésre, és tudván, hogy az enzim 20\%-os strukturális és szekvenciabeli hasonlóságot is mutat a BcnI enzimmel a hipotézisünk megalapozottnak tűnt (Janulaitis és mtsai., 1982; Kaus-Drobek és mtsai., 2007; Sokolowska és mtsai., 2007).

Annak megállapítására, hogy az MvaI a metilált BcnI hely G- vagy a C-szálát hasítja, in vitro M.SssI-el metilált, és MvaI-el emésztett pUP41-et templátként használva, újra run-off szekvenálást végeztünk a plazmidon található $\mathrm{BcnI}_{2411}$ hely esetén, mindkét irányból. Amikor a G-szálat használtuk templátnak, a szekvenálási jel hirtelen lecsökkent a BcnI helynél a citozin 3'-oldalán, míg a C-szál esetén folytatódott, jelezvén, hogy az enzim a G közepű szálat hasítja (20. ábra).

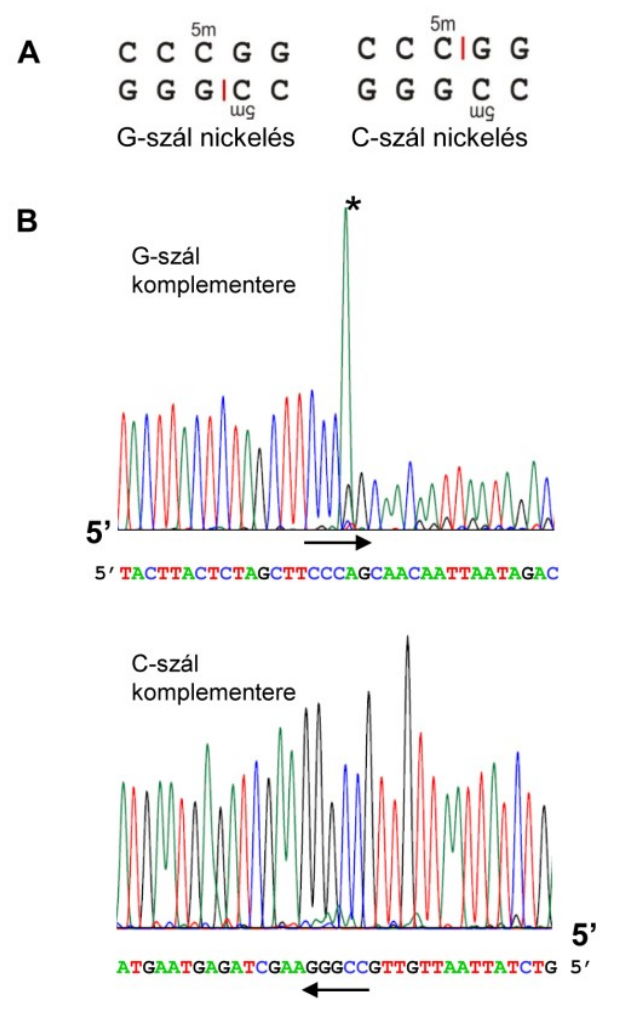

20. ábra. MvaI általi szál-specifikus hasítás M.SssI-metilált BcnI (CCSGG) hely esetén. (A) MvaI általi nickelés lehetséges helye M.SssI-metilált BcnI helynél. (B) A szekvenciameghatározás eredménye a pUP41 M.SssIspecifikusan metilált és MvaI-el emésztett BcnI 2411 helyénél. A csillag a Taq-polimeráz nem-templátspecifikus müködése következtében hozzáadott adenint jelöli (Clark, 1988). 
Ahhoz, hogy megállapítsuk, hogy a BcnI hely mely szálának metilációja szükséges az egyszálú hasításhoz, metilálatlan, hemimetilált vagy mindkét szálon metilált BcnI helyet tartalmazó, radioaktívan jelölt oligonukleotid duplexeket emésztettünk az MvaI endonukleázzal. A hemimetilált duplexek abban különböztek egymástól, hogy a metilációt különböző DNS szálon hordozták: az AK253/254 esetén a G-szál (C ${ }^{\mathrm{m} 5} \mathrm{CGGG/CCCGG)}$ míg az AK252/255 esetén a C-szál (CCGGG/CC $\left.{ }^{\mathrm{m} 5} \mathrm{CGG}\right)$ volt metilált. Minden esetben a G-szál hasítása vagy a BcnI hely teljes kétszálú emésztése egy 19 nukleotid nagyságú egyszálú fragmentum megjelenését eredményezi a denaturáló poliakrilamid gélen (21. ábra/A). A hemimetilált illetve mindkét szálon metilált duplexek nagyrésze emésztődött, ami azt mutatta, hogy a BcnI hely bármelyik szálának CG-specifikus metilációja kiváltja a G-szál MvaI általi hasítását. A teljesen metilált BcnI helyek valamivel jobb szubsztrátnak bizonyultak, mint a hemimetiláltak (21. ábra/B).

A

$19 \mathrm{nt}$

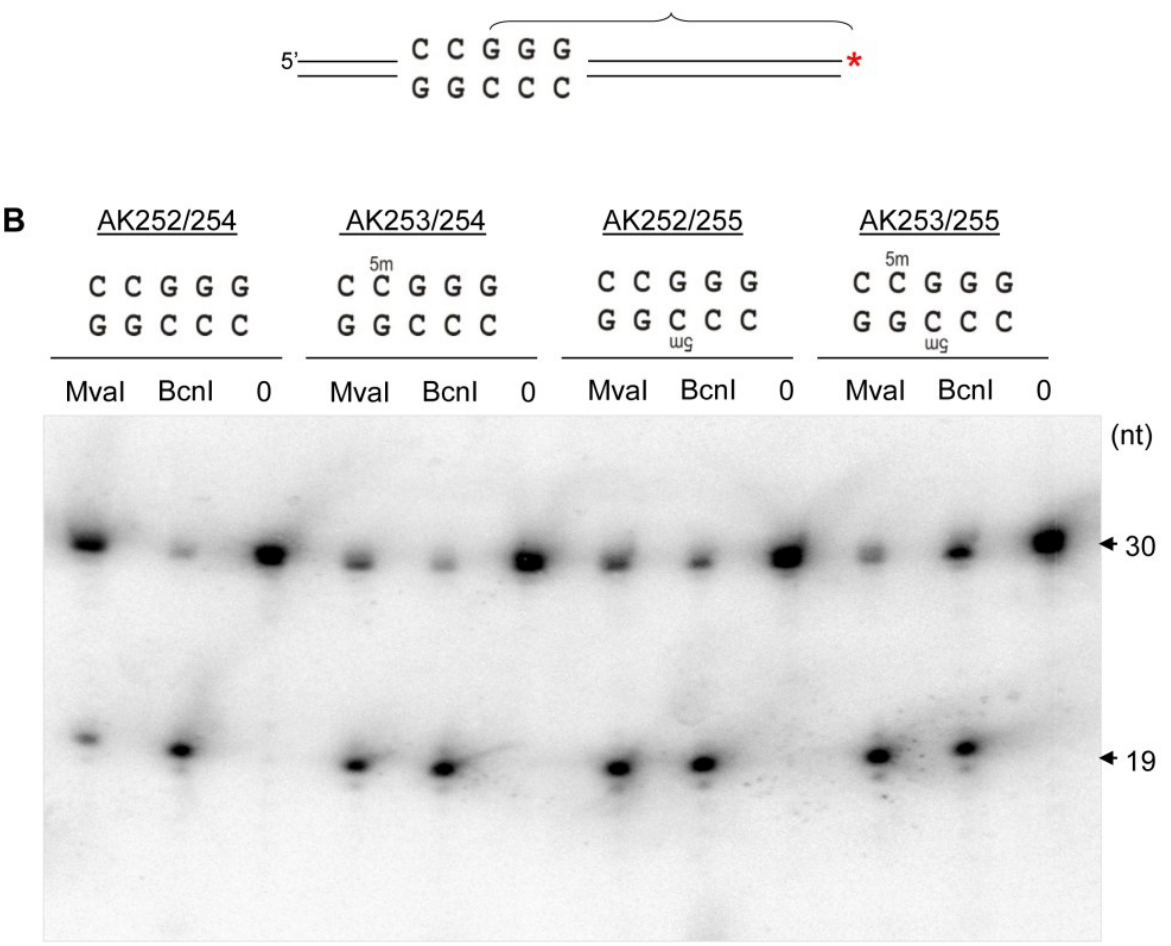

21. ábra. Metilálatlan (AK252/254), hemimetilált (AK253/AK254 és AK252/AK255) vagy mindkét szálon metilált (AK253/AK255) BcnI helyeket tartalmazó oligonukleotidok MvaI emésztése. (A) Az emésztéshez használt oligonukleotid sematikus ábrája. A 30bp nagyságú duplexek G közepű szála a 3' végen radioaktívan jelölt. A 19nt nagyságú oligonukleotid megjelenése a G-szál hasítására utal. (B) Az emésztmények denaturáló poliakrilamid gélelektroforézise. MvaI - MvaI által emésztett, BcnI - BcnI által emésztett, 0 - emésztetlen minta. 
A metilálatlan duplex nagymértékben, de nem teljesen volt rezisztens az MvaI emésztésre (21. ábra/B). Úgy gondoltuk, hogy a kis mennyiségben megjelenő emésztési termék ebben az esetben az oligonukleotidok nem teljes hibridizációjának következtében megmaradó egyszálú fragmentumok hasításának eredménye lehet, az 5'-jelölést viselő AK252 oligonukleotid esetén azonban nem tapasztaltunk MvaI emésztést. Ez arra utalt, hogy az enzim a metilálatlan BcnI helyeket is képes hasítani. Hogy ennek mértékéröl kvantitatív adatot kapjunk, elvégeztük a phosphor-image által alkotott kép denzitometriai analízisét (az ImageQuant szoftver felhasználásával. Az oligonukleotidok kémiai szintéziséből illetve a hibridizáció során fellépő lehetséges hibák elkerülése végett, a kísérlethez egy gélből tisztított DNS-fragmentumot használtunk. A pUC18 AvaII-SspI (444bp) fragmentuma kanonikus MvaI felismerési helyet (CCWGG) nem és csak egyetlen BcnI helyet (CCSGG) tartalmaz. A G-szál nickelése ezen a helyen egy 175 nukleotid nagyságú egyszálú fragmentumot eredményez (22. ábra/A). A phosphor-image egyszerü vizuális elemzésével (22. ábra/B) ebben az esetben is megfigyelhető volt kismértékü nickelés, a kép denzitometriai vizsgálata alapján azonban elmondható, hogy e fragmentumok intenzitása, így maga a metilálatlan BcnI hely hasítása, elhanyagolható mértékü (22. ábra/ C). Ez összhangban van eddigi eredményünkkel, miszerint a metilálatlan SmaI helyeknél nincs MvaI emésztés. 
A

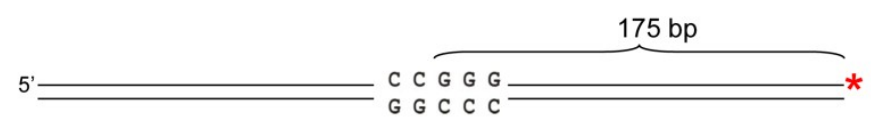

B

C
D

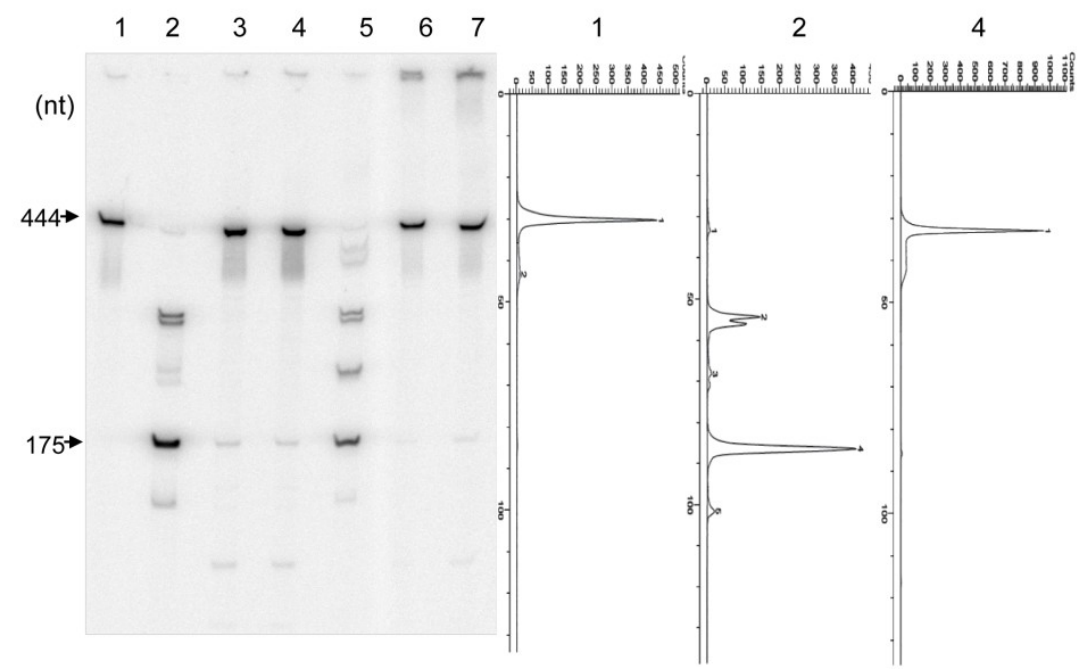

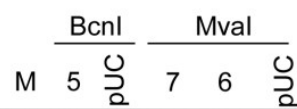

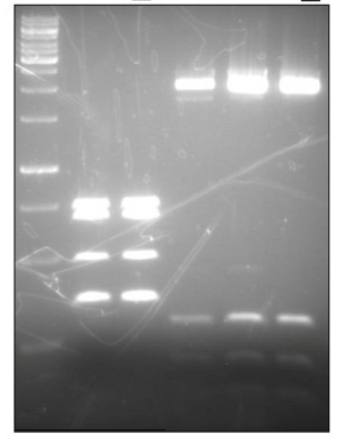

22. ábra. Egyetlen metilálatlan BcnI helyet tartalmazó DNS-fragmentum MvaI emésztése. (A). A pUC18-ból származó AvaII-SspI fragmentum sematikus ábrázolása. A 444bp nagyságú fragmentum G közepü szála a 3' végen radioaktívan jelölt. A BcnI hely kettősszálú hasítása valamint a G-szál nickelése egy 175nt nagyságú egyszálú fragmentum megjelenését eredményezi. (B). Az MvaI emésztmények denaturáló poliakrilamid gélelektroforézise. 1 - emésztetlen; 2 és 5 - BcnI-el emésztett; 3 és 6 - 0,5 U/ $\mu 1 \mathrm{MvaI-el}$ emésztett; 4 és 7 - 1 U/ $\mu 1$ MvaI-el emésztett minták. Az 5, 6 és 7 sávban található minták jelöletlen pUC18-at is tartalmaztak, hogy az emésztés teljességét ellenőrizni tudjuk agaróz gélen is. (C) Az 1, 2 és 4 sávban található minták emésztésének denzitometriás analízise. A görbék az emésztményben megjelenő egyes fragmentumok intenzitását mutatják. (D) Az 5, 6 és 7 sávban található minták emésztésének agaróz gélelektroforézise. pUC - pUC18 plazmid DNS teljes emésztése MvaI és BcnI enzimekkel, M - DNS marker. 


\section{Az eredmények megvitatása}

\section{M.SssI által katalizált citozin és 5-metilcitozin dezamináció}

A C5-citozin metiltranszferázok által katalizált DNS metiláció mind prokariótákban mind eukariótákban fontos molekuláris mechanizmus, mely számos biológiai folyamat szabályozásában vesz részt. A metilációs mintázat nem egy stabilan meghatározott jelleg, hanem egy folyamatosan, dinamikusan változó tulajdonság, amely az adott DNS-t tartalmazó sejtek illetve szövetek aktuális funkciójától függ, illetve szabályozza azt. Számos betegség hátterében a nem megfelelő epigenetikai szabályozás áll, így kiemelt fontosságúnak tekinthetőek azok a kutatások, melyek a genomi metilációs mintázat, vagy génspecifikus DNS metiláció vizsgálatát teszik lehetővé. A DNS-ben található 5metilcitozinok azonosítására illetve a metilációs mintázat megállapítására leggyakrabban alkalmazott módszer, a citozin illetve 5-metilcitozin biszulfittal való eltérő reaktivitásán alapuló, ún. biszulfit szekvenálás (Frommer és mtsai., 1992). Az egymás után következő kémiai reakciókból álló többlépéses módszer számos előnye és sokrétü felhasználása ellenére sem mondható tökéletesnek: a nem teljes citozin konverzió, illetve a biszulfit kezelés során fellépő DNS degradáció az eredmény téves értékeléséhez vezethet (Warnecke és mtsai., 2002). Figyelembe véve, hogy a biszulfit által katalizált citozin $\rightarrow$ uracil konverzió nagy hasonlóságot mutat az egyes prokarióta metiltranszferázok által katalizált citozin dezaminációhoz, doktori munkám során azt kívántuk vizsgálni, hogy a CG-specifikus M.SssI felhasználható-e, mint enzimatikus alternatíva, a CG szekvenciákon belül található 5-metilcitozinok kimutatására. Az M.SssI felhasználásának legnagyobb előnye abban rejlik, hogy szemben a biszulfittal, az enzimatikus dezamináció szubsztrátja a kettősszálú DNS-ben található citozin, így elkerülhető lenne a biszulfitos konverzióhoz használt reakciókörülmények (alacsony pH, hosszú inkubáció, magas hőmérséklet) miatt megfigyelhető DNS degradáció.

\section{M.SssI által katalizált in vitro dezamináció}

Az M.SssI általi citozin dezaminációra vonatkozó irodalmi adatok ellentmondásosak. Egy antibiotikum-rezisztencia reverzióján alapuló tesztet használva két csoport is kimutatta az enzim által katalizált $\mathrm{C} \rightarrow \mathrm{U}$ konverziót (Bandaru és mtsai., 1995; Zingg és mtsai., 1996). Egy harmadik csoport, egy inaktív lacZ gén reverzióján alapuló 
vizsgálattal sem az M.SssI, sem a M.HpaII általi dezaminációra nem kapott bizonyítékot (Zhang és Mathews, 1994). Végezetül, egy teljesen in vitro rendszert használva Métivier és munkacsoportja azt kapta, hogy az M.SssI nemcsak a citozin, de az 5-metilcitozin dezaminációjára is képes (Métivier és mtsai., 2008). Ezek tudatában elsőként tisztázni szerettük volna ezt az ellentmondást, másrészt, ha lehetséges, megtalálni azokat a körülményeket, ahol az M.SssI a legnagyobb citozin dezaminációs aktivitást mutatja. Eltérően a korábbi vizsgálatoktól, mi nem kereskedelmi, hanem saját magunk által tisztított enzimpreparátumot használtunk, ami lehetővé tette a reakció sztöchiometrikus viszonyainak jobb kontrollálását.

A munka során kimutattuk, hogy metildonor (SAM) hiányában, az M.SssI képes kettősszálú DNS szubsztrát esetén a CG szekvenciákban található citozint uracillá dezaminálni. Egy SAM analóg, az 5'-amino-5'-dezoxiadenozin, nagymértékben felgyorsítja ezt a reakciót, de érdekes módon, a SAM általi gátló hatást nem tudja legyőzni. Az M.SssI citozin dezaminációs képességére vonatkozó eredményeink összhangban vannak az irodalomban közölt három másik csoport munkájával (Bandaru és mtsai., 1995; Métivier és mtsai., 2008; Zingg és mtsai., 1996), de mivel az általunk használt kísérleti körülmények (mint az inkubáció ideje, hőmérséklet, $\mathrm{pH}, \mathrm{Mg}^{2+}$ hiánya a reakcióhoz használt pufferben) eltérnek az eddigiektől, a kvantitatív eredmények összehasonlítása nem teljesen egyértelmü. Az általunk alkalmazott kísérleti körülmények közt (4 óra, $30^{\circ} \mathrm{C}$, $\mathrm{pH}=8,5)$ az M.SssI-el in vitro mért átlagos reverziós gyakoriság $\sim 2,7 \times 10^{-4}$, amely egy nagyságrenddel nagyobb, mint a Bandaru és munkatársai által közölt, $37^{\circ} \mathrm{C}$-on mért érték (Bandaru és mtsai., 1995). Zingg és munkatársai ugyancsak $37^{\circ} \mathrm{C}$-on vizsgálták a dezaminációt, és 16 órás inkubáció után mértek az általunk megfigyelthez hasonló reverziós gyakoriságot (Zingg és mtsai., 1996). Kérdéses, hogy az enzim mennyire marad stabil ilyen hosszú időn keresztül. A kísérleteinkhez használt körülmények közt a kanamicin-rezisztencia visszatérésének gyakorisága 4 óra után már nem mutatott számottevő növekedést, ami arra enged következtetni, hogy a dezamináció sebessége, nagy valószínüséggel az enzim aktivitásának romlása miatt, idővel csökken. Csoportunk előzetes munkái során arra a következtetésre jutott, hogy az M.SssI $30^{\circ} \mathrm{C}$-on nagyobb metiltranszferáz aktivitással rendelkezik, mint a széles körben alkalmazott $37^{\circ} \mathrm{C}$-on. Figyelembe véve, hogy a metilációs és dezaminációs reakció kezdeti lépései hasonló útvonalat követnek, elképzelhető, hogy az általunk mért magasabb reverziós gyakoriság, vagyis gyorsabb dezamináció az alkalmazott hőmérsékleten megfigyelhető, jobb 
enzimmüködés következménye. Az M.SssI és 250 $4 \mathrm{M}$ 5'-amino-5'-dezoxiadenozin együttes hatására a kanamicin-rezisztencia megjelenésének gyakorisága $\sim 3,3 \times 10^{-3}$-ra nőtt, ami közel áll a Zingg és munkacsoportja által, 16 óra után kapott értékhez (Zingg és mtsai., 1996).

Az M.SssI-el végzett munkát arra a feltevésre alapoztuk, hogy a citozin és 5metilcitozin eltérő érzékenységet mutatnak az M.SssI által katalizált dezaminációval szemben. Feltevésünk abból a megfigyelésből ered, hogy a C5-citozin metiltranszferázok által katalizált dezaminációs reakció mechanizmusa hasonló a biszulfit általi $\mathrm{C} \rightarrow \mathrm{U}$ konverzióhoz. Mindkét reakció során egy instabil 5,6-dihidrocitozin intermedier jön létre, melynek spontán, hidrolitikus dezaminációja könnyen végbemegy (Hayatsu és mtsai., 1970; Shapiro és mtsai., 1973; Zingg és mtsai., 1996). Egyszálú DNS esetén a citozin és 5metilcitozin biszulfittal szembeni reakcióképessége nagyon eltérő: a biszulfit által indukált $\mathrm{C} \rightarrow \mathrm{U}$ konverzió $\sim 50$-szer gyorsabb, mint az ugyanilyen körülmények közt megfigyelhető a ${ }^{\mathrm{m} 5} \mathrm{C} \rightarrow \mathrm{T}$ dezamináció (Wang és mtsai., 1980). A kanamicin-rezisztencia reverzióján alapuló tesztet használva összehasonlítottuk a kettősszálú DNS-ben található citozin és 5metilcitozin M.SssI által katalizált dezaminációját, és kimutattuk, hogy 5'-amino-5'dezoxiadenozin jelenlétében ez utóbbinál a reverzió gyakorisága, és feltehetően a dezamináció sebessége is, legalább százszor alacsonyabb, mint a citozin esetén.

A biszulfit konverzió felhasználását az 5-metilcitozinok azonosítására alapvetően két tényező teszi lehetővé: egyrészt a szubsztrátok (metilálatlan és metilált citozinok) megbízható megkülönböztetése, másrészt a DNS-ben található citozinok konverziójának teljessége.

$\mathrm{Az}$ első tényező a citozin és 5-metilcitozin biszulfittal való eltérő reakcióképességéből adódik, melynek hátterében az áll, hogy a reakció végbemeneteléhez szükséges szulfonát-addukt metilált citozin esetén sokkal lassabban jön létre (Wang és mtsai., 1980). M.SssI-el végzett kísérleteink során kimutattuk, hogy a citozin és 5metilcitozin eltérö érzékenységet mutat az enzim által katalizált dezamináció esetén is, így a metiltranszferáz nagy biztonsággal alkalmazható a két bázis megkülönböztetésére.

A DNS-ben található citozinok konverziójának teljessége leginkább a reakció sebességétől függ. A lacZ gén reverzióján alapuló teszttel Chen és Shaw kimutatták, hogy egyszálú DNS esetén, fiziológiás körülmények közt $\left(37^{\circ} \mathrm{C}, \mathrm{pH}=7,4\right)$, a biszulfit általi citozin dezamináció következtében kapott revertánsok gyakorisága egy napi inkubáció 
után $\sim 2 \times 10^{-4}$, ami $10^{-10} / \mathrm{s}$ nagyságrendü dezaminációs sebességnek felel meg (Chen és Shaw, 1993). Ez az érték, melyet 50mM biszulfit felhasználásával kaptak, közel áll, sőt némileg alacsonyabb is, mint az általunk M.SssI-el kapott reverziós gyakoriság. Az általánosan elterjedt biszulfit szekvenálási protokollok (lásd pl. Clark és mtsai., 2006) azonban ennél jóval drasztikusabb körülményeket $\left(5-10 \mathrm{M}\right.$ biszulfit, $\left.55^{\circ}-65^{\circ} \mathrm{C}, \mathrm{pH}=5,5\right)$ javasolnak az egyszálú DNS-ben található citozinok teljes konverziójának eléréséhez. Ismert ugyanis, hogy a reakció sebessége a hőmérséklet és a biszulfit koncentráció emelésével jelentősen növelhető (Hayatsu, 2008; Hayatsu és mtsai., 1970, 2004; Shiraishi és Hayatsu, 2004; Sono és mtsai., 1973). Ezek alapján elmondható, hogy az M.SssI által katalizált dezamináció, jelenlegi formájában túl lassú a gyakorlati felhasználáshoz. A metiltranszferáz által katalizált dezamináció egy jól meghatározott körülmények közt végbemenő enzimatikus reakció, melynek paraméterei csak szűk keretek közt változtathatóak anélkül, hogy ellentétes (gátló) hatást fejtsenek ki. Az enzim dezaminációs aktivitásának ,javítására” elméletileg van lehetőség pl. irányított evolúcióval. Erre a következő kísérleti stratégia kínálkozik: különböző in vitro módszerekkel, mint pl. a hibázásra hajlamos PCR (Spee és mtsai., 1993) vagy a hipermutagén PCR (Buchholz és mtsai., 1998), random mutációkat hozunk létre az sssIM génben, majd egy, a mutáns génvariánsokat hordozó plazmidkönyvtárat felhasználva, megnövekedett citozin dezaminációt mutató variánsokra szelektálunk. A munka során létrehozott ER2357-kanS ung törzs lehetőséget ad egy erős szelekciós rendszer kialakítására, hisz a mutáns plazmidok ebbe a gazdába történő transzformálása és a bizonyos idő után megjelenő kanamicin-rezisztens revertánsok kiválogatásával kiszürhetőek a számunkra lényeges mutánsok. Ezek újbóli mutagenezise, és a baktériumsejtek egyre rövidebb idejü növesztése után megjelenő kanamicin-rezisztensek szelekciója várhatóan elvezethet a megnövekedett dezaminációs aktivitással rendelkező M.SssI variánsok feldúsulásához.

\section{M.SssI enzimvariánsok által katalizált in vivo citozin dezamináció}

Az M.SssI által katalizált in vitro citozin dezamináció mellett vizsgálni kívántuk az enzim felhasználhatóságát in vivo, SAM jelenlétében is. Ennek érdekében helyspecifikus mutagenezissel létrehoztunk két mutáns enzimet. Az enzim feltételezett SAM kötő motívumában levő F17S és G19D aminosavcserék, a metildonorhoz való affinitás csökkentése révén, az alacsony SAM koncentráció során fellépő körülményeket voltak hivatva utánozni in vivo. Az eredetileg a HpaII metiltranszferáz esetén alkalmazott megközelítés (Shen és mtsai., 1995) az M.SssI-nél is célravezető volt: a G19D 
enzimvariáns megnövekedett dezaminációs aktivitással rendelkezett $E$. coli sejtekben. A metiltranszferázok dezaminációs aktivitását két különböző rendszerben is megvizsgáltuk. Az egyik esetben a célszekvenciát tartalmazó kanamicin-rezisztencia gén és a metiltranszferáz génje két különbözö plazmidon, a másik esetben az elöbbi a gazdasejt kromoszómáján volt. Az első, két plazmidot tartalmazó rendszerben az sssIM allél egy alacsony-, a másik esetben viszont egy magas kópiaszámú plazmidon volt, ami eltérő intracelluláris enzim koncentrációt eredményezett a két gazdában. Uracil-DNS glikozilázzal nem rendelkező (Ung-) sejtek esetén az M.SssI(G19D) mindkét rendszerben megnövelte a kanamicin-rezisztens kolóniák gyakoriságát, míg a WT és F17S variánsoknak nem volt kimutatható hatása. Az enzim által indukált $\mathrm{C} \rightarrow \mathrm{U}$ mutációs ráta növekedését fluktuációs teszttel is kimutattuk. Érdekes módon a G19D által kiváltott megnövekedett reverziós gyakoriság $\mathrm{Ung}^{+}$gazdában is kimutatható volt, ami arra utal, hogy az enzim jelenléte nem csak átmeneti mutációk gyakoribb megjelenését, de valószínűleg javításuk gátlásán keresztül - stabilizálódásukat is elősegíti. Ez összhangban van az M.HpaII enzimmel kapott eredményekkel, és azzal a megfigyeléssel, hogy a metiltranszferázok általában jobban kötődnek a felismerési helyen belül található hibás U:G bázispárokhoz, mint a helyes C:G bázispárokhoz (Shen és mtsai., 1995; Yang és mtsai., 1995).

A WT enzim in vivo dezaminációs aktivitásának hiánya első ránézésre ellentmond az in vitro eredményeknek, miszerint SAM hiányában az enzim tízszeresére növeli a kanamicin-rezisztencia gyakoriságát. Nem szabad azonban figyelmen kívül hagyni azt a tényt, hogy a metiltranszferázok, így az M.SssI által katalizált dezaminációt is, a SAM jelenléte már nagyon kis koncentrációban is gátolja. Noha pontosan nem tudjuk a használt E. coli sejtekben jelenlevő SAM mennyiségét, ez minden bizonnyal elegendő ahhoz, hogy megmagyarázza a WT enzim in vivo dezaminációs aktivitásának hiányát.

A mutáns enzimek alacsony metiltranszferáz aktivitása és a G19D által mutatott megnövekedett dezaminációs aktivitás in vivo a csökkent SAM kötő képesség következtében várt tulajdonságok. Az F17S és G19D szubsztitúciók az M.HpaII F38S és G40D aminosavcseréinek felelnek meg. A dezaminációs képességre gyakorolt hatásuk tekintetében elmondható, hogy a glicin cseréje mindkét enzim esetén nagyobb hatással volt, mint a fenilalaniné (Shen és mtsai., 1995). Az FxGxG motívumban található mindkét megváltoztatott aminosav erősen konzervált a C5-citozin metiltranszferázoknál, mutációjuk az M.HpaII, M.HhaI és az eukarióta Dnmt3a MTáz esetén is a metiltranszferáz 
aktivitás csökkenését eredményezte (Gowher és mtsai., 2006; Sankpal és Rao, 2002; Shen és mtsai., 1995). Az I. motívumban található glicin feltételezhetően a metiltranszferázok SAM kötése során végbemenő konformációváltozásában játszik szerepet melynek cseréje nagy oldallánccal, vagy negatív töltéssel rendelkező aminosavakra (mint pl. az aszparaginsav) meggátolja a helyes konformáció kialakulását, és így a DNS metilációs képesség elvesztéséhez vezet (Wilke és mtsai., 1988; Willcock és mtsai., 1994). Ilyen szempontból érdekes, hogy az általunk létrehozott M.SssI(G19D), a megfelelő M.HpaII variánssal ellentétben, mutat némi metilációs aktivitást, ami arra enged következtetni, hogy az M.SssI „rugalmasabb” a metildonorral való interakciókban.

Eredményeink azt mutatják, hogy az M.SssI(G19D) in vivo CG specifikus dezaminázként működik, ami felveti annak a lehetőségét, hogy az enzimet irányított $\mathrm{C} \rightarrow \mathrm{T}$ mutációk létrehozására használjuk in vivo. A lehetséges felhasználási mód nagyban hasonlít az irányított DNS metiláció során alkalmazott módszerhez (Jeltsch és mtsai., 2007; Xu és Bestor, 1997): az enzimet genetikailag vagy kémiailag hozzá lehet kapcsolni specifikus nukleotidszekvenciákat felismerő irányító doménekhez, mint pl. cink-ujj fehérjék vagy tripla-hélix-formáló oligonukleotidok, melyek révén meghatározott CG szekvenciák közelébe irányítható, ahol a célzott citozin dezaminációja nagy valószínűséggel végbemegy majd. Az M.SssI(G19D) két fontos tulajdonsággal is rendelkezik, mely az említett felhasználásra alkalmassá teszi. Az irányított DNS metilációhoz kapcsolódó kutatások során kiderült, hogy az alacsonyabb metiltranszferáz aktivitással rendelkező mutáns enzimekkel nagyobb specificitás érhető el (Chaikind és mtsai., 2012; van der Gun és mtsai., 2010), így várható, hogy a G19D viszonylag alacsony citozin dezaminációs aktivitása ilyen szempontból előnyös lesz. Másrészt, az Ung ${ }^{+}$ gazdában megfigyelt uracil javítással szembeni ellenállás fontos lehet az enzim által létrehozott pre-mutagén U:G bázispárok fenntartásában és a stabil T:A mutáns bázispárok kialakításában.

\section{MvaI, egy kettős specificitású restrikciós enzim}

Az IIP típusú MvaI restrikciós enzim a $C C \downarrow$ WGG szekvenciákat ismeri fel, melyeket, a nyíllal jelzett helyen, monomerként hasítva 5'-túlnyúló végeket eredményez. A kanonikus M.MvaI metiltranszferáz a felismerőhelyen belül található második citozint metilálja az N4 pozícióban, a restrikciós hasítás gátlásához vezetve (Butkus és mtsai., 1985; Kaus-Drobek és mtsai., 2007). A kanonikus hely citozinjainak C5-metilációja nem 
jelent védelmet a hasítással szemben. Az enzim egy érdekes jellegzetessége, hogy viszonylag jól tolerálja a felismerési hely számos más jellegü modifikációját is (Kubareva és mtsai., 1988). Az MvaI 20\%-os szekvenciabeli és strukturális hasonlóságot mutat a BcnI restrikciós endonukleázzal, amely a hasonló jellegü $\mathrm{CC} \downarrow$ SGG ( $\mathrm{S}$ lehet $\mathrm{C}$ vagy $\mathrm{G}$ ) helyeket ismeri fel (Janulaitis és mtsai., 1982; Kaus-Drobek és mtsai., 2007; Sokolowska és mtsai., 2007).

Az SssI MTázzal végzett kísérleteink ahhoz az érdekes megfigyeléshez vezettek, hogy az MvaI tulajdonképpen egy kettős specificitással rendelkező restrikciós endonukleáz. Kimutattuk, hogy a jól ismert felismerési hely (CC $\downarrow$ AGG/CC $\uparrow$ TGG) mellett az enzim képes a BcnI helyek nickelésére is, amennyiben az aláhúzással jelzett citozin C5-

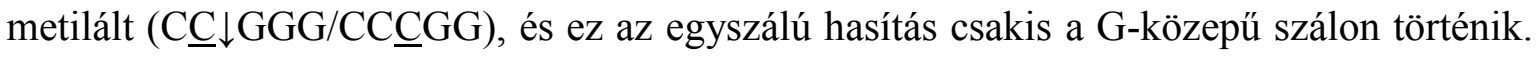
Mivel a két átfedő BcnI helyet tartalmazó SmaI (CCCGGG) helyek esetén a nickelések kétszálú DNS hasítást eredményeztek, össze tudtuk hasonlítani a két aktivitás (kanonikus és metiláció-függő) sebességét. A SmaI helyek metiláció-függő, kettősszálú hasítása sokkal lassabban megy végbe, mint a kanonikus helyek emésztése, mégis elég erős ahhoz, hogy ne egy furcsa mellékreakciónak tekintsük. Az MvaI által kifejtett metiláció-függő aktivitást két különböző kereskedelmi forgalomban levő preparátummal is ki tudtuk mutatni, melyek közül az egyik (Fermentas/Thermo Scientific) túltermelö E. coli sejtekböl, míg a másik (Sigma) a natív Micrococcus varians Rf119 gazdából származik. Ezek alapján elmondható, hogy az újonnan leírt aktivitás nem az enzimpreparátumok szennyeződésének következménye, hanem az MvaI egy jellemző tulajdonsága.

Az MvaI mellett még három olyan restrikciós enzim van (BcnI, HinPI és MspI) melyekről krisztallográfiás szerkezetük ismeretében tudjuk, hogy monomerként müködnek (Kaus-Drobek et al., 2007; Sokolowska et al., 2007; Xu et al., 2004; Yang, 2005). Mind a négy enzim palindróm, vagy közel palindróm szubsztráthellyel rendelkezik, melyeket aszimmetrikusan ismernek fel, kapcsolatot létesítve a DNS mindkét szálával. A felismerési komplexum aszimmetriája azt sugallja, hogy ezek az enzimek nickelő enzimként müködnek, és a kettősszálú DNS hasítást tulajdonképpen két egymás utáni egyszálú hasítás (nick) révén érik el. Ez a müködési mód eddig a HinPI és az MvaI endonukleázoknál bizonyított, sőt ez utóbbi esetén azt is kimutatták, hogy képes különbséget tenni a két szál közt, az A-közepű szálat gyorsabban hasítva (Horton, 2006; Kubareva és mtsai., 1991). Ez magyarázhatja a metiláció-függő aktivitás során megfigyelt purin közepü (G) szál preferenciális hasítását is. A nickelő mechanizmust alátámasztja továbbá az is, hogy mind 
az MvaI, mind a BcnI endonukleázok nagymértékü strukturális hasonlóságot mutatnak az össze nem illő bázispárok javításában résztvevő mutH fehérjével, mely nickelő enzimként működve, a hemimetilált $\mathrm{G}^{\mathrm{m} 6} \mathrm{ATC}$ szekvenciákat tartalmazó DNS metilálatlan szálát hasítja (Sokolowska és mtsai., 2007; Welsh és mtsai., 1987).

A kanonikus MvaI felismerési helyen az A/T kettősség figyelhető meg: az enzim felismeri az A:T vagy T:A (W) bázispárt, de nem fogadja el a G:C vagy C:G (S) bázispárokat. A szintén CCWGG szekvenciát felismerő PspGI endonukleáz a célszekvencia közepén található adenin DNS-ből való kilendítése révén tesz különbséget a bázisok között, az MvaI esetén azonban nem figyeltek meg ehhez hasonló mechanizmust (Szczepanowski és mtsai., 2008). Az intakt kettősszálú hélixben, a bázispárok geometriája és a hidrogénkötésekben potenciálisan résztvevő csoportok elhelyezkedése miatt, a $\mathrm{W}$ és $\mathrm{S}$ bázispárok megkülönböztetése kizárólag a DNS kis árka felőli interakciók révén valósulhat meg (Seeman és mtsai., 1976). A csoportunkban végzett kutatások eredményei is azt mutatják azonban, hogy ez a mechanizmus kevésbé specifikus, mint a jól meghatározott bázispárok nagy árki felismerése. Így például a GGWCC szekvenciákat felismerő SinI metiltranszferáz, gyengébben ugyan, de a GGSCC szekvenciákat is képes metilálni. Mi több, viszonylag egyszerü olyan megváltozott, relaxált specificitású M.SinI mutánsokat létrehozni, melyek képtelenek különbséget tenni a két szekvencia közt, ami szintén azt mutatja, hogy a W illetve $\mathrm{S}$ bázispárok felismerése sokkal kevésbé szigorúan körülhatárolt, mint egyetlen, jól meghatározott bázispár esetén (Kiss és mtsai., 2001; Timar, 2004). Az MvaI DNS-el alkotott kokristályának szerkezetéből nem teljesen egyértelmü, hogyan ismeri fel az enzim az A:T illetve T:A bázispárokat, hiszen a kristályban a lehetséges kötődési módok közül egy alkalommal mindig csak az egyiket vizsgálták (Kaus-Drobek és mtsai., 2007). Az MvaI-el végzett munka során kapott eredmények azt mutatják, hogy a CㅡGGG/CCㅡGG szekvenciák aláhúzással jelölt citozinjainak C5-metilációja nagymértékben csökkenti az enzim W és $\mathrm{S}$ bázispárok közti diszkriminációs képességét. Az egyik módosított citozin a BcnI hely közepén található, melyet a kanonikus felismerési szekvenciában az A:T bázispár foglal el. A DNS nagy árka felől a C5-metilcitozin nagyon hasonló a timinhez, ezért feltételezhető, hogy tulajdonképpen ez teszi lehetővé a metilált BcnI helyek MvaI általi felismerését. A kristályszerkezet alapján azonban, ez maga után vonná a C-közepủ szál hasítását, ami ellentmond eredményeinknek. Az MvaI endonukleáz szerkezetének további tanulmányozása talán választ adhat arra, hogy a citozin C5metilációja, hogyan váltja ki az észlelt specificitás változást. 
Az MvaI az első olyan restrikciós enzim mely, az aszimmetrikus szubsztrátfelismerés és a speciális, metilációt igénylő szubsztrátfelismerés kombinációja révén, kettős specificitással rendelkezik. Az új metiláció-függő aktivitás egyaránt jelenthet egyszálú ( $\mathrm{C}^{\mathrm{m} 5} \mathrm{C} \downarrow \mathrm{GGG} / \mathrm{CC}{ }^{\mathrm{m} 5} \mathrm{CGG}$ ) illetve kettősszálú ( $\left.\mathrm{CC}^{\mathrm{m} 5} \mathrm{C} \downarrow \mathrm{GGG} / \mathrm{CC}{ }^{\mathrm{m} 5} \mathrm{C} \uparrow \mathrm{GGG}\right)$ DNS specificitást, melyek eddig ismeretlenek voltak. Meg kell azonban jegyezni, hogy a metiláció-függő aktivitás esetén a szubsztráthely felismerése nem olyan szigorúan meghatározott, mint a kanonikus CCWGG helyé. 


\section{Köszönetnyilvánítás}

Elsősorban szeretném megköszönni témavezetőmnek, Dr. Kiss Antalnak a lehetőséget, hogy csoportjában dolgozhattam, a szakmai irányítást és a dolgozatom megírásához nyújtott nélkülözhetetlen segítségét és türelmét. Hálás vagyok, hogy tanácsaival körültekintő gondolkodásra és önálló kutatómunkára tanított.

Szintén köszönettel tartozom Anton Ibolyának a labormunkában nyújtott segítségért és gyakorlati tanácsaiért. Köszönöm a DNS-Fehérje Kölcsönhatások Csoport minden tagjának, föként Dr. Ślaska-Kiss Krystyna, Szentes Sarolta és Bádonyi Mihály segítségét és a kellemes, nyugodt légkört, amelyben munkámat végezhettem. Köszönöm az MTA SzBK, Biokémiai Intézetének a doktori tanulmányaimhoz nyújtott anyagi támogatást.

Nagyra értékelem Dr. Venetianer Pál és Dr. Tóth András javaslatait, mellyel hozzájárultak dolgozatom színvonalának növeléséhez.

Külön köszönet Méhi Orsolyának, Burcin Güngörnek és Begüm Pekselnek az együttérzésért és támogató barátságukért. A szüleimtől és családomtól kapott bátorítás és állandó érdeklődés sokat segített a nehézségek leküzdésében, ezért végtelenül hálás vagyok nekik. Végül, de nem utolsósorban, leginkább köszönöm Mihály Lászlónak, hogy megértő és kitartó társ volt, és a fizikai távolság ellenére mindig mellettem állt. 


\section{Hivatkozások jegyzéke}

Ammerpohl, O., Martín-Subero, J.I., Richter, J., Vater, I., and Siebert, R. (2009). Hunting for the 5th base: Techniques for analyzing DNA methylation. Biochim. Biophys. Acta BBA - Gen. Subj. 1790, 847-862.

Arber, W. (2000). Genetic variation: molecular mechanisms and impact on microbial evolution. FEMS Microbiol. Rev. 24, 1-7.

Bandaru, B., Wyszynski, M., and Bhagwat, A.S. (1995). Hpall methyltransferase is mutagenic in Escherichia coli. J. Bacteriol. 177, 2950-2952.

Bandaru, B., Gopal, J., and Bhagwat, A.S. (1996). Overproduction of DNA Cytosine Methyltransferases Causes Methylation and C T Mutations at Non-canonical Sites. J. Biol. Chem. $271,7851-7859$.

Beletskii, A., and Bhagwat, A.S. (2001). Transcription-Induced Cytosine-to-Thymine Mutations Are Not Dependent on Sequence Context of the Target Cytosine. J. Bacteriol. 183, 6491-6493.

Bestor, T.H. (2000). The DNA methyltransferases of mammals. Hum. Mol. Genet. 9, 2395-2402.

Bradford, M.M. (1976). A rapid and sensitive method for the quantitation of microgram quantities of protein utilizing the principle of protein-dye binding. Anal. Biochem. 72, 248-254.

Buchholz, F., Angrand, P.-O., and Stewart, A.F. (1998). Improved properties of FLP recombinase evolved by cycling mutagenesis. Nat. Biotechnol. 16, 657-662.

Buryanov, Y., and Shevchuk, T. (2005). The use of prokaryotic DNA methyltransferases as experimental and analytical tools in modern biology. Anal. Biochem. 338, 1-11.

Butkus, V., Klimasauskas, S., Kerśulyté, D., Vaitkevićius, D., Lebionka, A., and Janulaitis, A. (1985). Investigation of restriction-modification enzymes from M. varians RFL19 with a new type of specificity toward modification of substrate. Nucleic Acids Res. 13, 5727-5748.

Chaikind, B., Kilambi, K.P., Gray, J.J., and Ostermeier, M. (2012). Targeted DNA Methylation Using an Artificially Bisected M.Hhal Fused to Zinc Fingers. PLoS ONE 7, e44852.

Chen, H., and Shaw, B.R. (1993). Kinetics of bisulfite-induced cytosine deamination in singlestranded DNA. Biochemistry (Mosc.) 32, 3535-3539.

Chen, L., MacMillan, A.M., Chang, W., Ezaz-Nikpay, K., Lane, W.S., and Verdine, G.L. (1991). Direct identification of the active-site nucleophile in a DNA (cytosine-5)-methyltransferase. Biochemistry (Mosc.) 30, 11018-11025.

Cheng, X., and Roberts, R.J. (2001). AdoMet-dependent methylation, DNA methyltransferases and base flipping. Nucleic Acids Res. 29, 3784-3795.

Cheng, X., Kumar, S., Posfai, J., Pflugrath, J.W., and Roberts, R.J. (1993). Crystal structure of the Hhal DNA methyltransferase complexed with S-adenosyl-L-methionine. Cell 74, 299-307. 
Clark, J.M. (1988). Novel non-templated nucleotide addition reactions catalyzed by procaryotic and eucaryotic DNA polymerases. Nucleic Acids Res. 16, 9677-9686.

Clark, S.J., Statham, A., Stirzaker, C., Molloy, P.L., and Frommer, M. (2006). DNA methylation: Bisulphite modification and analysis. Nat. Protoc. 1, 2353-2364.

Collier, J. (2009). Epigenetic regulation of the bacterial cell cycle. Curr. Opin. Microbiol. 12, 722729.

Dahl, C., and Guldberg, P. (2003). DNA methylation analysis techniques. Biogerontology 4, 233250.

Darii, M.V., Kirsanova, O.V., Drutsa, V.L., Kochetkov, S.N., and Gromova, E.S. (2007). Isolation and site-directed mutagenesis of DNA methyltransferase SssI. Mol. Biol. 41, 110-117.

Durfee, T., Nelson, R., Baldwin, S., Plunkett, G., Burland, V., Mau, B., Petrosino, J.F., Qin, X., Muzny, D.M., Ayele, M., et al. (2008). The Complete Genome Sequence of Escherichia coli DH10B: Insights into the Biology of a Laboratory Workhorse. J. Bacteriol. 190, 2597-2606.

Estabrook, R.A. (2004). The Coupling of Tight DNA Binding and Base Flipping: Identification of a Conserved Structural Motif in Base Flipping Enzymes. J. Biol. Chem. 279, 31419-31428.

Frederico, L.A., Kunkel, T.A., and Shaw, B.R. (1990). A sensitive genetic assay for the detection of cytosine deamination: determination of rate constants and the activation energy. Biochemistry (Mosc.) 29, 2532-2537.

Frommer, M., McDonald, L.E., Millar, D.S., Collis, C.M., Watt, F., Grigg, G.W., Molloy, P.L., and Paul, C.L. (1992). A genomic sequencing protocol that yields a positive display of 5-methylcytosine residues in individual DNA strands. Proc. Natl. Acad. Sci. 89, 1827-1831.

Fuks, F. (2005). DNA methylation and histone modifications: teaming up to silence genes. Curr. Opin. Genet. Dev. 15, 490-495.

Galm, O. (2001). Enzymatic Regional Methylation Assay: A Novel Method to Quantify Regional CpG Methylation Density. Genome Res. 12, 153-157.

Gong, W., O'Gara, M., Blumenthal, R.M., and Cheng, X. (1997). Structure of Pvull DNA-(cytosine N4) methyltransferase, an example of domain permutation and protein fold assignment. Nucleic Acids Res. 25, 2702-2715.

Gowher, H., Loutchanwoot, P., Vorobjeva, O., Handa, V., Jurkowska, R.Z., Jurkowski, T.P., and Jeltsch, A. (2006). Mutational Analysis of the Catalytic Domain of the Murine Dnmt3a DNA(cytosine C5)-methyltransferase. J. Mol. Biol. 357, 928-941.

Van der Gun, B.T.F., Maluszynska-Hoffman, M., Kiss, A., Arendzen, A.J., Ruiters, M.H.J., McLaughlin, P.M.J., Weinhold, E., and Rots, M.G. (2010). Targeted DNA Methylation by a DNA Methyltransferase Coupled to a Triple Helix Forming Oligonucleotide To Down-Regulate the Epithelial Cell Adhesion Molecule. Bioconjug. Chem. 21, 1239-1245.

Guzman, L.-M., Belin, D., Carson, M.J., and Beckwith, J.O.N. (1995). Tight regulation, modulation, and high-level expression by vectors containing the arabinose PBAD promoter. J. Bacteriol. 177, 4121-4130. 
Hall, B.M., Ma, C.-X., Liang, P., and Singh, K.K. (2009). Fluctuation AnaLysis CalculatOR: a web tool for the determination of mutation rate using Luria-Delbruck fluctuation analysis. Bioinformatics $25,1564-1565$.

Hayatsu, H. (2008). Discovery of bisulfite-mediated cytosine conversion to uracil, the key reaction for DNA methylation analysis-a personal account. Proc. Jpn. Acad. Ser. B 84, 321-330.

Hayatsu, H., Wataya, Y., Kai, K., and lida, S. (1970). Reaction of sodium bisulfite with uracil, cytosine, and their derivatives. Biochemistry (Mosc.) 9, 2858-2865.

Hayatsu, H., Negishi, K., and Shiraishi, M. (2004). DNA methylation analysis: speedup of bisulfitemediated deamination of cytosine in the genomic sequencing procedure. Proc. Jpn. Acad. Ser. B 80, 189-194.

Hermann, A., Gowher, H., and Jeltsch, A. (2004). Biochemistry and biology of mammalian DNA methyltransferases. Cell. Mol. Life Sci. 61, 2571-2587.

Horton, J.R. (2004). Caught in the act: visualization of an intermediate in the DNA base-flipping pathway induced by Hhal methyltransferase. Nucleic Acids Res. 32, 3877-3886.

Horton, J.R. (2006). DNA nicking by HinP1l endonuclease: bending, base flipping and minor groove expansion. Nucleic Acids Res. 34, 939-948.

Huang, N., Banavali, N.K., and MacKerell, A.D. (2003). Protein-facilitated base flipping in DNA by cytosine-5-methyltransferase. Proc. Natl. Acad. Sci. 100, 68-73.

Janulaitis, A.A., Petrusite, M.A., Jaskelavicene, B.P., Krayev, A.S., Skryabin, K.G., and Bayev, A.A. (1982). A new restriction endonuclease Bcnl from Bacillus centrosporus RFL 1. FEBS Lett. 137, 178-180.

Jeltsch, A. (2002). Beyond Watson and Crick: DNA methylation and molecular enzymology of DNA methyltransferases. Chembiochem 3, 274-293.

Jeltsch, A. (2003). Maintenance of species identity and controlling speciation of bacteria: a new function for restriction/modification systems? Gene 317, 13-16.

Jeltsch, A., Jurkowska, R.Z., Jurkowski, T.P., Liebert, K., Rathert, P., and Schlickenrieder, M. (2007). Application of DNA methyltransferases in targeted DNA methylation. Appl. Microbiol. Biotechnol. $75,1233-1240$.

Jessen, W.J., Dhasarathy, A., Hoose, S.A., Carvin, C.D., Risinger, A.L., and Kladde, M.P. (2004). Mapping chromatin structure in vivo using DNA methyltransferases. Methods 33, 68-80.

Jones, P.A. (2001). The Role of DNA Methylation in Mammalian Epigenetics. Science 293, 10681070.

Kagan, R.M., and Clarke, S. (1994). Widespread Occurrence of Three Sequence Motifs in Diverse SAdenosylmethionine-Dependent Methyltransferases Suggests a Common Structure for These Enzymes. Arch. Biochem. Biophys. 310, 417-427.

Kaus-Drobek, M., Czapinska, H., Sokolowska, M., Tamulaitis, G., Szczepanowski, R.H., Urbanke, C., Siksnys, V., and Bochtler, M. (2007). Restriction endonuclease Mval is a monomer that recognizes its target sequence asymmetrically. Nucleic Acids Res. 35, 2035-2046. 
Kiss, A., Pósfai, G., Zsurka, G., Raskó, T., and Venetianer, P. (2001). Role of DNA minor groove interactions in substrate recognition by the M.Sinl and M.EcoRII DNA (cytosine-5) methyltransferases. Nucleic Acids Res. 29, 3188-3194.

Klimasauskas, S., Timinskas, A., Saulius, M., Butkienè, D., Butkus, V., and Janulaitis, A. (1989). Sequence motifs characteristic of DNA[cytosine-N4]methyltransferases: similarity to adenine and cytosine-C5 DNA-methylases. Nucleic Acids Res. 17, 9823-9832.

Klimasauskas, S., Kumar, S., Roberts, R.J., and Cheng, X. (1994). Hhal methyltransferase flips its target base out of the DNA helix. Cell 76, 357-369.

Klimasuaskas, S., Nelson, J.L., and Roberts, R.J. (1991). The sequence specificity domain of cytosine-C5 methylases. Nucleic Acids Res. 19, 6183-6190.

Klose, R.J., and Bird, A.P. (2006). Genomic DNA methylation: the mark and its mediators. Trends Biochem. Sci. 31, 89-97.

Kobayashi, I. (2001). Behavior of restriction-modification systems as selfish mobile elements and their impact on genome evolution. Nucleic Acids Res. 29, 3742-3756.

Koudan, E.V., Bujnicki, J.M., and Gromova, E.S. (2004). Homology Modeling of the CG-specific DNA Methyltransferase Sssl and its Complexes with DNA and AdoHcy. J. Biomol. Struct. Dyn. 22, 339345.

Kubareva, E.A., Gromova, E.S., Pein, C.-D., Krug, A., Oretskaya, T.S., Cech, D., and Shabarova, Z.A. (1991). Oligonucleotide cleavages by restriction endonucleases Mval and EcoRII: a comprehensive study on the influence of structural. Biochim. Biophys. Acta BBA - Gene Struct. Expr. 1088, 395400 .

Kubareva, E.A., Pein, C.-D., Gromova, E.S., Kuznezova, S.A., Tashlitzki, V.N., Cech, D., and Shabarova, Z.A. (1988). The role of modifications in oligonucleotides in sequence recognition by Mval restriction endonuclease. Eur. J. Biochem. 175, 615-618.

Kumar, S., Cheng, X., Klimasauskas, S., Mi, S., Posfai, J., Roberts, R.J., and Wilson, G.G. (1994). The DNA (cytosine-5) methyltransferases. Nucleic Acids Res. 22, 1-10.

Kunkel, T.A. (1985). Rapid and efficient site-specific mutagenesis without phenotypic selection. Proc. Natl. Acad. Sci. 82, 488-492.

Labahn, J., Granzin, J., Schluckebier, G., Robinson, D.P., Jack, W.E., Schildkraut, I., and Saenger, W. (1994). Three-dimensional structure of the adenine-specific DNA methyltransferase M. Taq I in complex with the cofactor S-adenosylmethionine. Proc. Natl. Acad. Sci. 91, 10957-10961.

Lacks, S., and Greenberg, B. (1975). A deoxyribonuclease of Diplococcus pneumoniae specific for methylated DNA. J. Biol. Chem. 250, 4060-4066.

Laird, P.W. (2010). Principles and challenges of genome-wide DNA methylation analysis. Nat. Rev. Genet. 11, 191.

Lauster, R., Trautner, T.A., and Noyer-Weidner, M. (1989). Cytosine-specific type II DNA methyltransferases: A conserved enzyme core with variable target-recognizing domains. J. Mol. Biol. 206, 305-312. 
Lederberg, E.M., and Cohen, S.N. (1974). Transformation of Salmonella typhimurium by plasmid deoxyribonucleic acid. J. Bacteriol. 119, 1072-1074.

Li, E., Bestor, T.H., and Jaenisch, R. (1992). Targeted mutation of the DNA methyltransferase gene results in embryonic lethality. Cell 69, 915-926.

Li, E., Beard, C., and Jaenisch, R. (1993). Role for DNA methylation in genomic imprinting. Nature 366, 362-365.

Luria, S.E., and Delbruck, M. (1943). Mutations of Bacteria from Virus Sensitivity to Virus Resistance. Genetics 28, 491-511.

Lutsenko, E., and Bhagwat, A.S. (1999). Principal causes of hot spots for cytosine to thymine mutations at sites of cytosine methylation in growing cells: A model, its experimental support and implications. Mutat. Res. Mutat. Res. 437, 11-20.

Marinus, M.G., and Casadesus, J. (2009). Roles of DNA adenine methylation in host-pathogen interactions: mismatch repair, transcriptional regulation, and more. FEMS Microbiol. Rev. 33, 488-503.

Matsuo, K., Silke, J., Gramatikoff, K., and Schaffner, W. (1994). The CpG-specific methylase Sssl has topoisomerase activity in the presence of $\mathrm{Mg}^{2+}$. Nucleic Acids Res. 22, 5354-5349.

Métivier, R., Gallais, R., Tiffoche, C., Le Péron, C., Jurkowska, R.Z., Carmouche, R.P., Ibberson, D., Barath, P., Demay, F., Reid, G., et al. (2008). Cyclical DNA methylation of a transcriptionally active promoter. Nature $452,45-50$.

Mi, S., and Roberts, R.J. (1992). How M. Msp I and M. Hpa II decide which base to methylate. Nucleic Acids Res. 20, 4811-4816.

Mi, S., and Roberts, R.J. (1993). The DNA binding affinity of Hhal methylase is increased by a single amino acid substitution in the catalytic center. Nucleic Acids Res. 21, 2459-2464.

Mi, S., Alonso, D., and Roberts, R.J. (1995). Functional analysis of Gln-237 mutants of Hhal methyltransferase. Nucleic Acids Res. 23, 620-627.

Mohandas, T., Sparkes, R.S., and Shapiro, L.J. (1981). Reactivation of an inactive human X chromosome: evidence for X inactivation by DNA methylation. Science 211, 393-396.

Morgan, R.D., Calvet, C., Demeter, M., Agra, R., and Kong, H. (2000). Characterization of the Specific DNA Nicking Activity of Restriction Endonuclease N.BstNBI. Biol. Chem. 381.

Nelson, M., Raschke, E., and McClelland, M. (1993). Effect of site-specific methylation on restriction endonucleases and DNA modification methyltransferases. Nucleic Acids Res. 21, 31393154.

Pingoud, A., and Jeltsch, A. (2001). Structure and function of type II restriction endonucleases. Nucleic Acids Res. 29, 3705-3727.

Pósfai, G., Koob, M.D., Kirkpatrick, H.A., and Blattner, F.R. (1997). Versatile insertion plasmids for targeted genome manipulations in bacteria: isolation, deletion, and rescue of the pathogenicity island LEE of the Escherichia coli 0157:H7 genome. J. Bacteriol. 179, 4426-4428. 
Pósfai, J., Bhagwat, A.S., Pósfai, G., and Roberts, R.J. (1989). Predictive motifs derived from cytosine methyltransferases. Nucleic Acids Res. 17, 2421-2435.

Raleigh, E.A. (1992). Organization and function of the mcrBC genes of Escherichia coli K-12. Mol. Microbiol. 6, 1079-1086.

Raleigh, E.A., and Wilson, G. (1986). Escherichia coli K-12 restricts DNA containing 5methylcytosine. Proc. Natl. Acad. Sci. 83, 9070-9074.

Raskó, T., Der, A., Klement, E., Ślaska-Kiss, K., Posfai, E., Medzihradszky, K.F., Marshak, D.R., Roberts, R.J., and Kiss, A. (2010). BspRI restriction endonuclease: cloning, expression in Escherichia coli and sequential cleavage mechanism. Nucleic Acids Res. 38, 7155-7166.

Rathert, P., Raskó, T., Roth, M., Ślaska-Kiss, K., Pingoud, A., Kiss, A., and Jeltsch, A. (2007). Reversible Inactivation of the CG Specific SssI DNA (Cytosine-C5)-Methyltransferase with a Photocleavable Protecting Group. ChemBioChem 8, 202-207.

Reinisch, K.M., Chen, L., Verdine, G.L., and Lipscomb, W.N. (1995). The crystal structure of Haell methyltransferase covalently complexed to DNA: An extrahelical cytosine and rearranged base pairing. Cell 82, 143-153.

Renbaum, P., and Razin, A. (1992). Mode of action of the Spiroplasma CpG methylase M. Sssl. FEBS Lett. 313, 243-247.

Renbaum, P., and Razin, A. (1995). Footprint analysis of M. Sssl and M. Hhal methyltransferases reveals extensive interactions with the substrate DNA backbone. J. Mol. Biol. 248, 19-26.

Renbaum, P., Abrahamove, D., Fainsod, A., Wilson, G.G., Rottem, S., and Razin, A. (1990). Cloning, characterization, and expression in Escherichia coli of the gene coding for the CpG DNA methylase from Spiroplasma sp. strain MQ1 (M Sssl). Nucleic Acids Res. 18, 1145-1152.

Roberts, R.J. (2003). A nomenclature for restriction enzymes, DNA methyltransferases, homing endonucleases and their genes. Nucleic Acids Res. 31, 1805-1812.

Roberts, R.J. (2005). How restriction enzymes became the workhorses of molecular biology. Proc. Natl. Acad. Sci. 102, 5905-5908.

Roberts, R.J., Vincze, T., Posfai, J., and Macelis, D. (2010). REBASE-a database for DNA restriction and modification: enzymes, genes and genomes. Nucleic Acids Res. 38, D234-D236.

Rosche, W.A., and Foster, P.L. (2000). Determining Mutation Rates in Bacterial Populations. Methods 20, 4-17.

Russel, M., Kidd, S., and Kelley, M.R. (1986). An improved filamentous helper phage for generating single-stranded plasmid DNA. Gene 45, 333-338.

Sambrook, J., and Russell, D.W. (2006). The condensed protocols from molecular cloning: a laboratory manual (Cold Spring Harbor Laboratory Press Cold Spring Harbor, NY).

Sankpal, U.T., and Rao, D.N. (2002). Mutational analysis of conserved residues in thal DNA methyltransferase. Nucleic Acids Res. 30, 2628-2638. 
Seeman, N.C., Rosenberg, J.M., and Rich, A. (1976). Sequence-specific recognition of double helical nucleic acids by proteins. Proc. Natl. Acad. Sci. 73, 804-808.

Selker, E.U. (1990). Premeiotic instability of repeated sequences in Neurospora crassa. Annu. Rev. Genet. 24, 579-613.

Shapiro, R., Braverman, B., Louis, J.B., and Servis, R.E. (1973). Nucleic acid reactivity and conformation II. Reaction of cytosine and uracil with sodium bisulfite. J. Biol. Chem. 248, 40604064.

Sharath, A.N., Weinhold, E., and Bhagwat, A.S. (2000). Reviving a Dead Enzyme: Cytosine Deaminations Promoted by an Inactive DNA Methyltransferase and an $S$-Adenosylmethionine Analogue ${ }^{\dagger}$. Biochemistry (Mosc.) 39, 14611-14616.

Shen, J.-C., Rideout III, W.M., and Jones, P.A. (1992). High frequency mutagenesis by a DNA methyltransferase. Cell 71, 1073-1080.

Shen, J.-C., Rideout, W.M., and Jones, P.A. (1994). The rate of hydrolytic deamination of 5methylcytosine in double-stranded DNA. Nucleic Acids Res. 22, 972-976.

Shen, J.-C., Zingg, J.-M., Yang, A.S., Schmutte, C., and Jones, P.A. (1995). A mutant Hpall methyltransferase functions as a mutator enzyme. Nucleic Acids Res. 23, 4275-4282.

Shiraishi, M., and Hayatsu, H. (2004). High-speed conversion of cytosine to uracil in bisulfite genomic sequencing analysis of DNA methylation. DNA Res. 11, 409-415.

Sibley, M.H., and Raleigh, E.A. (2011). A versatile element for gene addition in bacterial chromosomes. Nucleic Acids Res. 40, e19-e19.

Smith, H.O., and Welcox, K.W. (1970). A Restriction enzyme from Hemophilus influenzae: I. Purification and general properties. J. Mol. Biol. 51, 379-391.

Sokolowska, M., Kaus-Drobek, M., Czapinska, H., Tamulaitis, G., Siksnys, V., and Bochtler, M. (2007). Restriction endonucleases that resemble a component of the bacterial DNA repair machinery. Cell. Mol. Life Sci. 64, 2351-2357.

Sono, M., Wataya, Y., and Hayatsu, H. (1973). Role of bisulfite in the deamination and the hydrogen isotope exchange of cytidylic acid. J. Am. Chem. Soc. 95, 4745-4749.

Spee, J.H., Vos, W.M. de, and Kuipers, O.P. (1993). Efficient random mutagenesis method with adjustable mutation frequency by use of PCR and dITP. Nucleic Acids Res. 21, 777-778.

Suzuki, M.M., and Bird, A. (2008). DNA methylation landscapes: provocative insights from epigenomics. Nat. Rev. Genet. 9, 465-476.

Szczepanowski, R.H., Carpenter, M.A., Czapinska, H., Zaremba, M., Tamulaitis, G., Siksnys, V., Bhagwat, A.S., and Bochtler, M. (2008). Central base pair flipping and discrimination by PspGl. Nucleic Acids Res. 36, 6109-6117.

Tímár, E., Groma, G., Kiss, A., and Venetianer, P. (2004). Changing the recognition specificity of a DNA-methyltransferase by in vitro evolution. Nucleic Acids Res. 32, 3898-3903. 
Trautner, T.A., Pawlek, B., Behrens, B., and Willert, J. (1996). Exact size and organization of DNA target-recognizing domains of multispecific DNA-(cytosine-C5)-methyltransferases. EMBO J. 15, 1434.

Vasu, K., and Nagaraja, V. (2013). Diverse Functions of Restriction-Modification Systems in Addition to Cellular Defense. Microbiol. Mol. Biol. Rev. 77, 53-72.

Vilkaitis, G. (2001). The Mechanism of DNA Cytosine-5 Methylation. Kinetic and Mutational Dissection of Hhal Methyltransferase. J. Biol. Chem. 276, 20924-20934.

Waite-Rees, P.A., Keating, C.J., Moran, L.S., Slatko, B.E., Hornstra, L.J., and Benner, J.S. (1991). Characterization and expression of the Escherichia coli Mrr restriction system. J. Bacteriol. 173, 5207-5219.

Wang, R.Y.-H., Gehrke, C.W., and Ehrlich, M. (1980). Comparison of bisulfite modification of 5methyldeoxycytidine and deoxycytidine residues. Nucleic Acids Res. 8, 4777-4790.

Warnecke, P.M., Stirzaker, C., Song, J., Grunau, C., Melki, J.R., and Clark, S.J. (2002). Identification and resolution of artifacts in bisulfite sequencing. Methods 27, 101-107.

Welsh, K.M., Lu, A.L., Clark, S., and Modrich, P. (1987). Isolation and characterization of the Escherichia coli mutH gene product. J. Biol. Chem. 262, 15624-15629.

Wilke, K., Rauhut, E., Noyer-Weidner, M., Lauster, R., Pawlek, B., Behrens, B., and Trautner, T.A. (1988). Sequential order of target-recognizing domains in multispecific DNA-methyltransferases. EMBO J. 7, 2601.

Willcock, D.F., Dryden, D.T., and Murray, N.E. (1994). A mutational analysis of the two motifs common to adenine methyltransferases. EMBO J. 13, 3902.

Wilson, G.G., and Murray, N.E. (1991). Restriction and Modification Systems. Annu. Rev. Genet. $25,585-627$.

Woodcock, D.M., Crowther, P.J., Doherty, J., Jefferson, S., DeCruz, E., Noyer-Weidner, M., Smith, S.S., Michael, M.Z., and Graham, M.W. (1989). Quantitative evaluation of Escherichia coli host strains for tolerance to cytosine methylation in plasmid and phage recombinants. Nucleic Acids Res. 17, 3469-3478.

Wu, J.C., and Santi, D.V. (1987). Kinetic and catalytic mechanism of Hhal methyltransferase. J. Biol. Chem. 262, 4778-4786.

Wyszynski, M., Gabbara, S., and Bhagwat, A.S. (1994). Cytosine deaminations catalyzed by DNA cytosine methyltransferases are unlikely to be the major cause of mutational hot spots at sites of cytosine methylation in Escherichia coli. Proc. Natl. Acad. Sci. 91, 1574-1578.

Wyszynski, M.W., Gabbara, S., Kubareva, E.A., Romanova, E.A., Oretskaya, T.S., Gromova, E.S., Shabarova, Z.A., and Bhagwat, A.S. (1993). The cysteine conserved among DNA cytosine methylasesis required for methyl transfer, but not for specific DNA binding. Nucleic Acids Res. 21, 295-301.

Xu, G.-L., and Bestor, T.H. (1997). Cytosine methylation targetted to pre-determined sequences. Nat. Genet. 17, 376-378. 
Xu, Q.S., Kucera, R.B., Roberts, R.J., and Guo, H.-C. (2004). An Asymmetric Complex of Restriction Endonuclease Mspl on Its Palindromic DNA Recognition Site. Structure 12, 1741-1747.

Xu, S.-Y., Zhu, Z., Zhang, P., Chan, S.-H., Samuelson, J.C., Xiao, J., Ingalls, D., and Wilson, G.G. (2007). Discovery of natural nicking endonucleases Nb.BsrDI and Nb.Btsl and engineering of topstrand nicking variants from BsrDI and Btsl. Nucleic Acids Res. 35, 4608-4618.

Xu, Y., Lunnen, K.D., and Kong, H. (2001). Engineering a nicking endonuclease N.Alwl by domain swapping. Proc. Natl. Acad. Sci. 98, 12990-12995.

Yang, A.S., Shen, J.-C., Zingg, J.-M., Mi, S., and Jones, P.A. (1995). Hhal and Hpall DNA methyltransferases bind DNA mismatches, methylate uracil and block DNA repair. Nucleic Acids Res. 23, 1380-1387.

Yang, Z., Horton, J.R., Maunus, R., Wilson, G.G., Roberts, R.J., and Cheng, X. (2005). Structure of HinP1l endonuclease reveals a striking similarity to the monomeric restriction enzyme Mspl. Nucleic Acids Res. 33, 1892-1901.

Yebra, M.J., and Bhagwat, A.S. (1995). A cytosine methyltransferase converts 5-methylcytosine in DNA to thymine. Biochemistry (Mosc.) 34, 14752-14757.

Yoder, J.A., Walsh, C.P., and Bestor, T.H. (1997). Cytosine methylation and the ecology of intragenomic parasites. Trends Genet. 13, 335-340.

Youngblood, B., Shieh, F.-K., Buller, F., Bullock, T., and Reich, N.O. (2007). S -Adenosyl- L methionine-Dependent Methyl Transfer: Observable Precatalytic Intermediates during DNA Cytosine Methylation. Biochemistry (Mosc.) 46, 8766-8775.

Zhang, X., and Mathews, C.K. (1994). Effect of DNA cytosine methylation upon deaminationinduced mutagenesis in a natural target sequence in duplex DNA. J. Biol. Chem. 269, 7066-7069.

Zingg, J.-M., Shen, J.-C., Yang, A.S., Rapoport, H., and Jones, P.A. (1996). Methylation inhibitors can increase the rate of cytosine deamination by (cytosine-5)-DNA methyltransferase. Nucleic Acids Res. 24, 3267-3275.

Zingg, J., Shen, J., and Jones, P. (1998). Enzyme-mediated cytosine deamination by the bacterial methyltransferase M. Mspl. Biochem J 332, 223-230. 


\section{Saját publikációk jegyzéke}

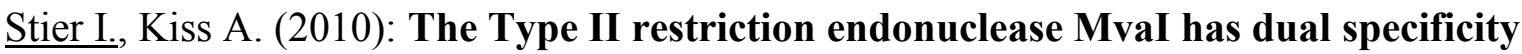

- Nucleic Acids Research 38: 8231-8238.

I.F. 7,836

Stier I., Kiss A. (2013): Cytosine-to-Uracil Deamination by SssI DNA

Methyltransferase - PLOS One 8(10): e79003. doi:10.1371/journal.pone.0079003

I.F. 3,730 


\section{Összefoglalás}

A DNS metiláció az epigenetikai szabályozás egyik fö összetevője, mely szerepet játszik többek közt a génkifejeződés, a genetikai bevésődés és az egyedfejlödés szabályozásában. Emlősök genomjában kizárólag C5-citozin metiláció figyelhető meg, amely föként a CG dinukleotidokban található citozinokat érinti. A reakciót a C5-citozin metiltranszferázok katalizálják, melyek egy aktivált metil csoportot juttatnak a citozin ötös szénatomjára az S-adenozil-L-metionint (SAM) használva donorként. A metilált citozinok térbeni és időbeni eloszlása nem véletlen, hanem egy jól meghatározott mintázatot követ. Ennek a helyes kialakítása és fenntartása elengedhetetlen a szervezet normális működéséhez (Jeltsch, 2002; Jones, 2001). A genomi DNS-ben levő 5-metilcitozinok azonosításának leggyakrabban alkalmazott módja az ún. biszulfitos DNS szekvenciameghatározás, amely azon a megfigyelésen alapszik, hogy egyszálú DNS-ben a nátrium-hidrogénszulfit sokkal gyorsabban képes specifikusan dezaminálni a citozint uracillá, mint ahogy azt az 5-metilcitozinnal teszi (Frommer és mtsai., 1992). A módszer egy nagy hátránya, hogy a reakció során használt körülmények esetenként a vizsgálni kívánt DNS degradációjához, és így az eredmény megbízhatatlanságához vezethetnek (Dahl és Guldberg, 2003; Warnecke és mtsai., 2002).

Az SssI metiltranszferáz az egyetlen olyan prokarióta enzim, mely az emlösökben található C5-MTázokhoz hasonlóan, a CG szekvenciákban levő citozint módosítja, így jól alkalmazható modellként és kísérleti eszközként a magasabbrendű eukariótákban előforduló citozin metiláció tanulmányozásában (Koudan és mtsai., 2004; Renbaum és mtsai., 1990). Korábban kimutatták, hogy metildonor hiányában az enzim képes a célszekvencián belül található citozint uracillá dezaminálni. A reakció feltehetőleg hasonló útvonalon keresztül megy végbe, mint a biszulfit általi $\mathrm{C} \rightarrow \mathrm{T}$ konverzió (Bandaru és mtsai., 1995; Métivier és mtsai., 2008; Zingg és mtsai., 1996). Ebből a hasonlóságból kiindulva doktori munkám során arra voltunk kíváncsiak, hogy az M.SssI felhasználható-e a kettősszálú DNS-ben, az epigenetikailag fontos CG dinukleotidokban található metilált és metilálatlan citozin megkülönböztetésére. Úgy gondoltuk az M.SssI felhasználása, mint enzimatikus alternatíva, lehetőséget ad a biszulfitos reakció használatát gyakran nehezítő egyes technikai problémák megkerülésére. 
Az M.SssI által katalizált dezamináció vizsgálatához egy inaktív kanamicinrezisztencia gén reverzióján alapuló tesztet használtunk. Az irodalmi adatok egy részét alátámasztva kimutattuk, hogy a metildonor hiányában az M.SssI valóban képes a citozint uracillá dezaminálni, és a reakció egy SAM analóg, az 5'-amino5'-dezoxiadenozin (AA) hozzáadásával felgyorsítható.

Egyszálú DNS-ben a biszulfit által indukált C-U konverzió ötvenszer gyorsabb, mint az ugyanilyen körülmények közt megfigyelhető ${ }^{\mathrm{m} 5} \mathrm{C} \rightarrow \mathrm{T}$ dezamináció (Wang és mtsai., 1980). Összehasonlítva a kettősszálú DNS-ben található citozin és 5-metilcitozin nukleotidok M.SssI által katalizált dezaminációjának sebességeit kimutattuk, hogy 5'amino-5'-dezoxiadenozin jelenlétében ez utóbbi legalább százszor lassúbb. Ez azt sugallja, hogy az M.SssI általi konverzió elég érzékeny ahhoz, hogy megbízhatóan megkülönböztesse a metilálatlan és metilált citozinokat. Mindemellett eredményeink azt mutatják, hogy az M.SssI által katalizált reakció jóval lassúbb folyamat, mint az általánosan használt körülmények közt végbemenő biszulfitos konverzió, így jelen formájában nem alkalmas a gyakorlati használatra.

Az M.SssI járulékos in vitro aktivitásának vizsgálata mellett arra is kíváncsiak voltunk, hogy felhasználható-e az enzim citozin dezaminációra in vivo, SAM jelenlétében. Ennek vizsgálatára, egy előzőleg a HpaII metiltranszferázzal végzett munka alapján (Shen és mtsai., 1995), létrehoztunk két mutáns enzimet. A C5-citozin metiltranszferázok közt erősen konzervált, feltehetőleg a SAM kötésében szerepet játszó I. motívum (Kumar és mtsai., 1994) Phe17 és Gly19 aminosavait helyspecifikus mutagenezissel szerinre illetve aszparaginsavra cseréltük. Az aminosavcserék, a metildonorhoz való affinitás csökkentése révén, az alacsony SAM koncentráció során fellépő körülményeket voltak hivatva utánozni in vivo. A létrehozott M.SssI(F17S) és M.SssI(G19D) mutáns enzimek dezaminációs aktivitását két különbözö E. coli gazdában is megvizsgáltuk. Az egyik esetben az sssIM allél és a célzott mutáns kanamicin (kanS) gén két különbözö plazmidon voltak, míg a másik gazdánál a kanS gén a kromoszómán volt. A G19D enzim variáns mindkét, uracilDNS glikozilázzal (Ung) nem rendelkező, gazda esetén tízszeresére növelte a citozin dezamináció sebességét, míg a WT enzim és az F17S mutáns esetén nem tapasztaltunk hatást. A megnövekedett $\mathrm{C} \rightarrow \mathrm{U}$ mutációs gyakoriságot fluktuációs teszttel is igazoltuk. Érdekes módon az M.SssI(G19D) mutáns $\mathrm{Ung}^{+}$gazda esetén is megnövekedett dezaminációs rátához vezetett, ami azt sugallja, hogy az enzim képes az uracil-DNS 
glikozilázhoz kapcsolt javítás gátlására. A mutánsok csökkent SAM kötő képességét az is alátámasztotta, hogy mind in vivo mind in vitro alacsonyabb metiltranszferáz aktivitással rendelkeztek, mint a vad típusú enzim.

A CG-specifikus M.SssI metiltranszferázzal végzett munka során észrevettük, hogy az M.SssI általi in vivo vagy in vitro metiláció új szubsztráthelyeket teremt az MvaI restrikciós enzim számára. Az új felismerési helyek megjelenése CG-metilációtól függött, és az MvaI endonukleázra specifikus volt, az enzim egy izoszkizomerje, a BstNI, nem ismerte fel öket.

Az MvaI restrikciós enzim kanonikus felismerési helye a 5'-CC $\downarrow$ AGG/5'-CC $\uparrow T G G$ szekvencia, melyet a nyilaknak megfelelően, monomerként hasít. Az enzim RM rendszerbeli társa, az MvaI MTáz, a felismerési szekvencia második citozinját metilálja N4 pozícióban $\left(\mathrm{C}^{\mathrm{m} 4} \mathrm{CAGG} / \mathrm{C}^{\mathrm{m} 4} \mathrm{CTGG}\right)$. A kanonikus hely citozinjainak $\mathrm{C}$-metilációja nem jelent védelmet a hasítással szemben (Butkus és mtsai., 1985; Kaus-Drobek és mtsai., 2007). Kimutattuk, hogy az MvaI restrikciós enzim a kanonikus kettősszálú hasítás mellett a metilált $\mathrm{BcnI}$ helyek $\left(\mathrm{C}^{\mathrm{m}} \mathrm{C}_{\downarrow} \mathrm{GGG} / \mathrm{CC}^{\mathrm{m} 5} \mathrm{CGG}\right)$ egyszálú hasítására (nick) is képes, a nyíllal jelölt pozícióban. $\mathrm{A} C \mathrm{C}^{\mathrm{m} 5} \mathrm{C} \downarrow \mathrm{GGG} / \mathrm{CC}^{\mathrm{m} 5} \mathrm{C} \uparrow \mathrm{GGG}$ szekvenciáknál (CG-metilált SmaI hely), ahol két ellentétes irányú metilált BcnI hely átfedő módon egymás mellé kerül, a metiláció-függő aktivitás kétszálú hasítást eredményez, ahogy a nyilak jelzik. A hasítás sebessége és a felismerés specifikussága ezeken a helyeken alacsonyabb, mint az enzim kanonikus aktivitása esetén.

Az MvaI az első példa arra, hogy egy restrikciós enzim kettős specificitással rendelkezhet, azaz a "szokásos" II. típusú endonukleázokra jellemző metilálatlan felismerőhely mellett egy attól eltérő szekvenciájú másik helyet is hasít, amennyiben az meghatározott módon metilált. Az MvaI metiláció-függő aktivitása egyszerre jelent egy- és kettősszálú specificitást $\left(\mathrm{C}^{\mathrm{m} 5} \mathrm{C} \downarrow \mathrm{GGG} / \mathrm{CC}^{\mathrm{m} 5} \mathrm{CGG}\right.$ és $\left.\mathrm{CC}^{\mathrm{m} 5} \mathrm{C} \downarrow \mathrm{GGG} / \mathrm{CC}^{\mathrm{m} 5} \mathrm{C} \uparrow \mathrm{GGG}\right)$, melyek eddig ismeretlenek voltak. 


\section{Summary}

DNA methylation, along with histone modification, is a major component of epigenetic regulation, being involved in processes, such as gene expression regulation, genetic imprinting or developmental regulation. In the genomes of vertebrates' only cytosines within $\mathrm{CpG}$ dinucleotides are methylated at the carbon-5. Cytosine methylation is catalyzed by DNA-cytosine methyltransferases, which transfer an activated methyl group from the donor S-adenosyl-L-methionine (SAM) to the carbon-5 of the cytosine. The genomic distribution of the methyl cytosine residues forms a pattern, which varies among species, and it is tissue specific. Properly established and maintained methylation patterns are essential for mammalian development and for normal function of the organism. The most widely used method for identification of methylated cytosine employs the treatment of genomic DNA with sodium-bisulfite. Upon this treatment unmethylated cytosines deaminate to uracil while 5-methylcytosines remain unchanged. Due to the harsh conditions used for the conversion reaction, the method is prone to certain reaction artefacts that affect its reliability (Dahl and Guldberg, 2003; Warnecke et al., 2002).

The prokaryotic DNA-(cytosine-5)-methyltransferase M.SssI shares the specificity of eukaryotic DNA methyltransferases (CG) and is an important model and experimental tool in the study of eukaryotic DNA methylation (Koudan et al., 2004; Renbaum et al., 1990). Previously, M.SssI was shown to be able to catalyze deamination of the target cytosine to uracil if the methyl donor SAM was missing from the reaction. The enzymatic cytosine deamination is assumed to follow a path analogous to that of bisulfite mediated Cto-T conversion (Bandaru et al., 1995; Métivier et al., 2008; Zingg et al., 1996). Based on this similarity, we wished to test whether the deamination side-activity of the M.SssI can be used to distinguish between unmethylated and C5-methylated cytosines in CG dinucleotides. The use of M.SssI as an enzymatic alternative to bisulfite conversion would give the possibility to bypass some of the technical difficulties associated with this method.

To test the deamination activity of the M.SssI MTase, we used a sensitive genetic assay based on the mutation in an inactive kanamycin resistance gene resulting in reversion to kanamycin resistant phenotype. Confirming some of the previous results we could show that M.SssI can deaminate cytosines to uracil in a slow reaction, and that the rate of the conversion can be increased by the SAM analogue 5'-amino-5' -deoxyadenosine (AA). 
In single-stranded DNA the rate of bisulfite mediated conversion of C-to- $\mathrm{U}$ is $\sim 50$ fold higher than the rate of ${ }^{\mathrm{m} 5} \mathrm{C}$-to-T conversion (Wang et al., 1980), which forms the basis of bisulfite-sequencing (Frommer et al., 1992). We compared the reactivities of cytosine and 5-methylcytosine in double stranded DNA to M.SssI mediated deamination and found that in the presence of AA the difference of the reaction rates is at least 100-fold. This suggests that the M.SssI-catalyzed conversion is sensitive enough to reliably discriminate between unmethylated and C5-methylated cytosines. However, our results show that the rate of M.SssI mediated cytosine deamination is still much slower than that obtained with standard bisulfite protocols, making the M.SssI mediated cytosine deamination, at present, impractical as an alternative method.

Besides studying this side activity of M.SssI in vitro, we wished to test whether the enzyme can be used to deaminate cytosines in vivo, in the presence of SAM. To this end we constructed two mutant enzymes based on previous work with the HpaII MTase (Shen et al., 1995). Amino acids Phe17 and Gly19 of conserved motif I, presumed to be part of the SAM binding pocket of the C5-DNA MTases (Kumar et al., 1994), were changed by site directed mutagenesis to Ser and Asp respectively. We expected the amino acid substitutions to weaken the cofactor binding abilities of the enzyme, and thus to mimic conditions of limiting SAM in vivo. The cytosine deamination activity of both mutant enzymes (F17S and G19D) was tested in two different E. coli hosts. In one of them the sssIM allele and the targeted kanS gene were on two separate plasmids, while the other host carried the $k a n S$ gene on the chromosome. The G19D variant caused a $\sim 10$-fold increase in the deamination rate in both types of hosts lacking uracil-DNA-glycosylase (Ung) related repair, while the WT enzyme and the F17S mutant had no effect. The elevated C-to-U reversion rate was also demonstrated by fluctuation test. Interestingly, M.SssI(G19D) increased the deamination rate also in $\mathrm{Ung}^{+}$hosts, suggesting that the enzyme can block uracil-DNA glycosylase mediated repair. Consistent with the envisioned effect of impaired SAM binding, both mutants had reduced methyltransferase activities in vivo and in vitro compared to WT.

In the course of our work with the CG-specific DNA cytosine-5 methyltransferase M.SssI, we noticed that in vivo or in vitro M.SssI methylation leads to the appearance of new substrate sites for the MvaI restriction enzyme. Appearance of these new sites was dependent on CG-methylation and it was specific for Mval, the phenomenon was not shown by its isoschizomer BstNI. 
The MvaI restriction endonuclease cuts $\mathrm{CC} \downarrow \mathrm{AGG} / \mathrm{CC} \uparrow \mathrm{TGG}$ sequences, as indicated by the arrows, as a monomer. The cognate MvaI MTase modifies the internal cytosine to produce N4-methylcytosine $\left(\mathrm{C}^{\mathrm{m} 4} \mathrm{CAGG} / \mathrm{C}^{\mathrm{m} 4} \mathrm{CTGG}\right)$. $\mathrm{C} 5$-methylation of the same cytosine does not protect the site against MvaI cleavage (Butkus et al., 1985; KausDrobek et al., 2007). We have shown that the MvaI endonuclease, in addition to its doublestranded cleavage activity on the canonical recognition sequence $(\mathrm{CC} \downarrow \mathrm{AGG} / \mathrm{CC} \uparrow \mathrm{TGG}$, nicks BcnI sites $\left(\mathrm{C}^{\mathrm{m} 5} \mathrm{C} \downarrow \mathrm{GGG} / \mathrm{CC}^{\mathrm{m} 5} \mathrm{CGG}\right)$ as indicated, if the inner cytosines are $\mathrm{C} 5$ methylated. This nicking activity results in double-strand scissions at $\mathrm{CC}^{\mathrm{m} 5} \mathrm{C} \downarrow \mathrm{GGG} / \mathrm{CC}{ }^{\mathrm{m} 5} \mathrm{C} \uparrow \mathrm{GGG}$ (CG-methylated SmaI) sites, where two oppositely oriented methylated BcnI sites overlap. The double-stranded cleavage rate and the stringency of the substrate site recognition are lower at the methylation-dependent site than at the canonical target sites.

MvaI formally combines features of "typical” Type II REases cutting unmethylated sequences, with those of methyl-directed Type II enzymes which require methylated substrate sites. To our knowledge, MvaI is the first REase, for which such dual specificity has been shown. The new, methylation-dependent activity represents nicking and doublestranded cleavage specificities $\left(\mathrm{C}^{\mathrm{m} 5} \mathrm{C} \downarrow \mathrm{GGG} / \mathrm{CC}{ }^{\mathrm{m} 5} \mathrm{CGG}\right.$ and $\mathrm{CC}^{\mathrm{m} 5} \mathrm{C} \downarrow \mathrm{GGG} / \mathrm{CC}^{\mathrm{m} 5} \mathrm{C} \uparrow \mathrm{GGG}$, respectively) not known before. 